\title{
DISPONIBILIDADE DE ÁGUA NO SOLO PARA PORTA-ENXERTOS DE CITROS EM ECOSSISTEMA DE TABULEIRO COSTEIRO
}

\author{
Fernando luis dultra Cintra \\ Engenheiro Agronômo
}

Orientador: Prof. Dr. PAULO LEONEL LIBARDI

Tese apresentada à Escola Superior de Agricultura "Luiz de Queiroz", Universidade de São Paulo, para obtenção do título de Doutor em Agronomia. Área de Concentração: Solos e Nutrição de Plantas.

P I R A C I C A B A

Estado de São Paulo - Brasil

Outubro - 1997 
Dados Internacionais de Catalogação na Publicação (CIP) DIVISÃO DE BIBLIOTECA E DOCUMENTAÇÃO - Campus "Luiz de Queiroz"/USP

\section{Cintra, Fernando Luis Dultra}

Disponibilidade de água no solo para porta-enxertos de citros em ecossistema de tabuleiro costeiro / Fernando Luis Dultra Cintra. - . Piracicaba, 1997.

$$
90 \text { p. : il. }
$$

Tese (doutorado) - Escola Superior de Agricultura Luiz de Queiroz, 1997.

Bibliografia.

1. Água no solo 2. Porta enxerto de fruta citrica 3. Raiz 4. Tabuleiro costeiro I. Título

CDD 631.432

634.31

631.541 


\section{DISPONIBILIDADE DE ÁGUA NO SOLO PARA PORTA-ENXERTOS DE CITROS EM ECOSSISTEMA DE TABULEIRO COSTEIRO}

FERNANDO LUIS DULTRA CINTRA

Aprovada em: 21/11/1997

Comissão julgadora:

Prof. Dr. Paulo Leonel Libardi

ESALQ/USP

Prof. Dr. Antonio Melhem Saad

$\mathrm{IPT} / \mathrm{SP}$

Prof. Dr. Marcos Vinícius Folegatti

ESALQ/USP

Prof. Dr. Sergio Oliveira Moraes

ESALQ/USP

Prof $^{\natural}$. Dr ${ }^{\mathrm{a}}$. Isabella Clerici de Maria

IAC/SP

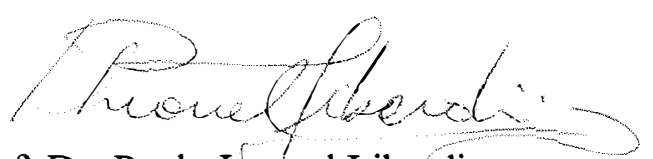

Prof. Dr. Paulo Leonel Libafdi

Orientador 
À minha esposa Ceiça e aos meus filhos Bruno, Fernanda e Carolina

\section{DEDICO}




\section{AGRADECIMENTOS}

\section{- Escola Superior de Agricultura “Luiz de Queiroz" (ESALQ/USP):}

Ao Professor Paulo Leonel Libardi pela orientação durante o curso.

Aos colegas de pós-graduação com quem convivi durante estes anos e que colaboraram de diversas formas para a concretização deste trabalho: Antônio M. Saad, Cláudio Marciano, Carmen V.J.Neves, Francisco R. C. Espírito Santo, Julio Rénan P.Alcaraz, Adeodato A. C. Salviano, Francisco Ocian, Maria do Rosário L. Rodrígues, João Batista Lopes, Zilton J. M. Cordeiro, Milcíades Gadelha e aos amigos Nelson e Cezira.

Ao Professor Sergio Oliveira Moraes pela prestimosa colaboração.

Aos funcionários do Laboratório de Física do Solo do Departamento de Física e Meteorologia Luiz Fernando Novello e Francisco Bernardo Dias.

\section{- EMBRAPA - Tabuleiros Costeiros (CPATC):} fevereiro de 1994.

À administração do Centro pelo apoio desde o início do curso em

A Robson Oliveira pela ajuda inestimável em todas as fases do trabalho.

Ao colega e pesquisador Roosevelt M. Prudente pela cessão do experimento de porta-enxerto.

A José Roque de Jesus pela realização das filmagens das trincheiras.

A Paulo Sérgio Santos da Mota pelo apoio durante a realização dos trabalhos no Campo Experimental de Umbaúba - CEU.

Aos funcionários do CEU, Gilberto, Acácio, Raimundo e Milton pela dedicação com que executaram suas funções.

Aos colegas pesquisadores do CPATC Antônio Carlos Barreto, Evandro de A. Tupinambá e Maria de Lourdes da S Leal pelo apoio e colaboração.

Ao pesquisador José Coelho A. Filho pela descrição e análise morfológica do perfil.

Ao Sr. Amâncio C. Santos pela ajuda na construção de vários equipamentos utilizados no trabalho de campo.

\section{- EMBRAPA- Instrumentação Agropecuária (CNPDIA):}

À administração do Centro pela cessão do Laboratório de imagens.

A Lúcio André de Castro Jorge pela ajuda e orientação nos estudos sobre sistema radicular.

A Ednaldo José Ferreira pela ajuda inestimável durante a aquisição e tratamento das imagens de raizes em computador. 


\section{SUMÁRIO}

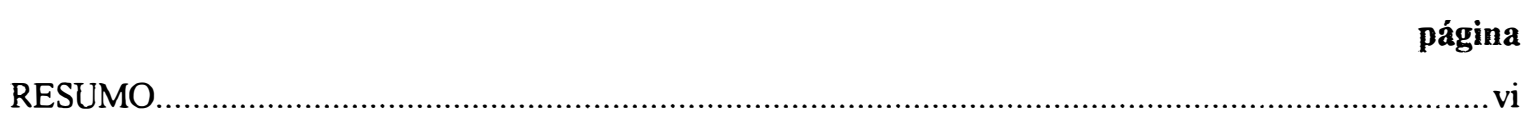

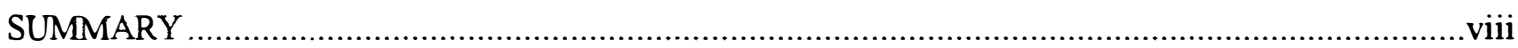

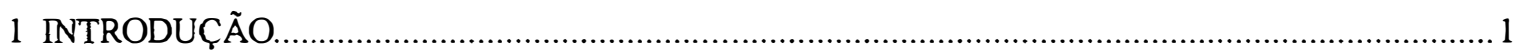

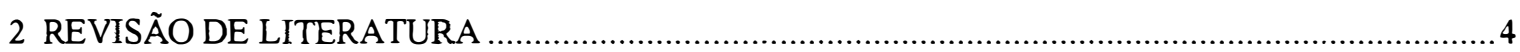

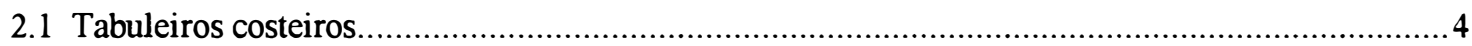

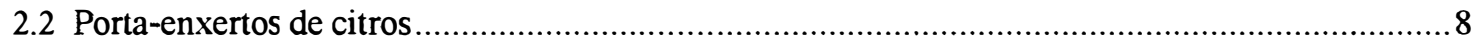

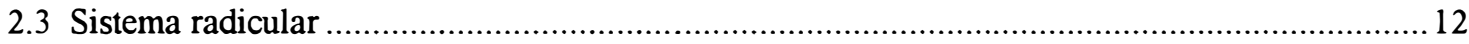

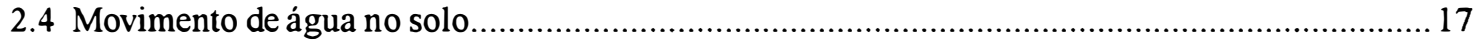

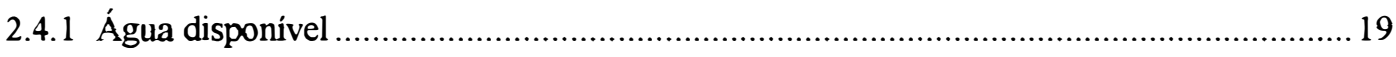

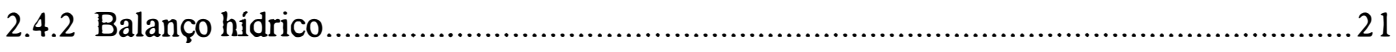

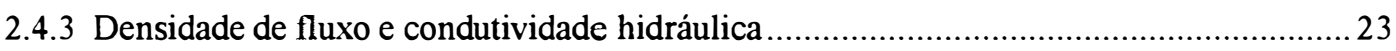

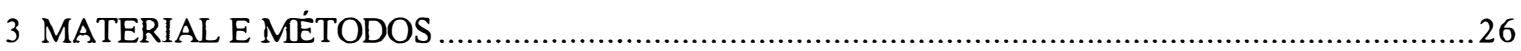

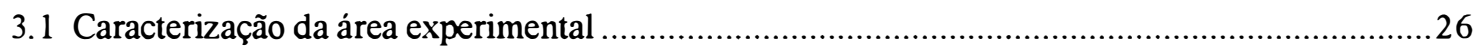

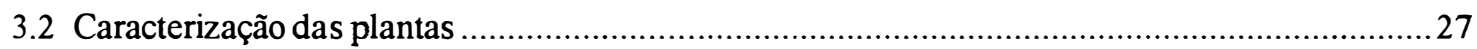

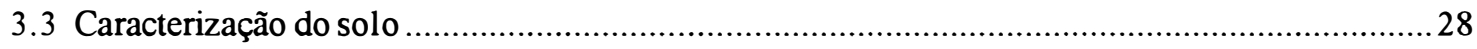

3.3.1 Classificação do solo, descrição da área e análise morfológica do perfil ..........................28

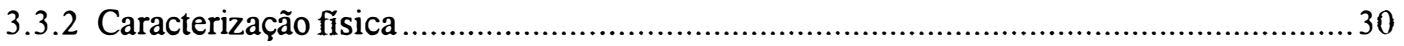

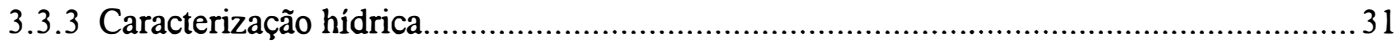

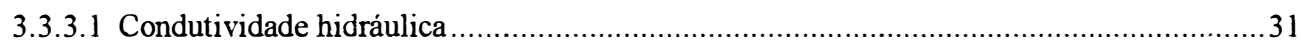

3.3.3.2 Determinação dos perfís de potencial mátrico em função do tempo ................................33

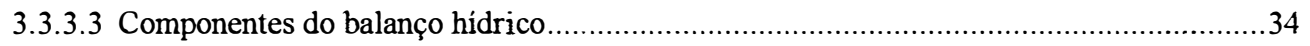

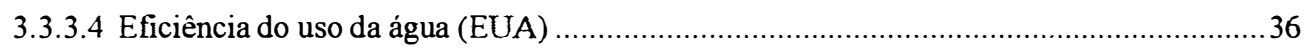

3.4 Avaliação da distribuição do sistema radicular dos porta enxertos ..............................................36 


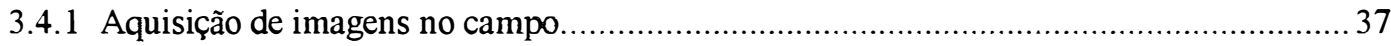

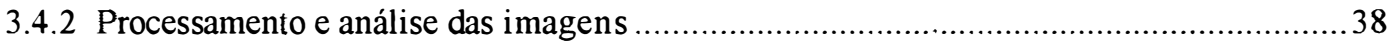

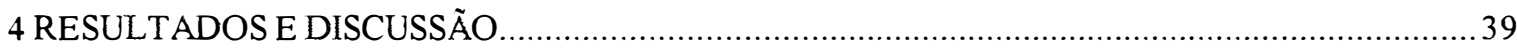

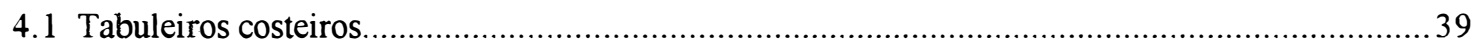

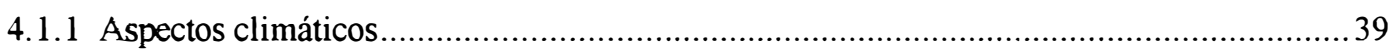

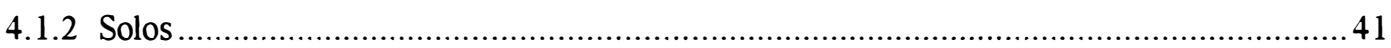

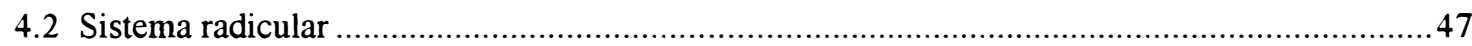

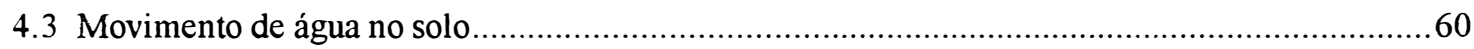

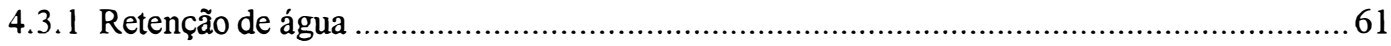

4.3.2 Condutividade hidráulica .................................................................. 63

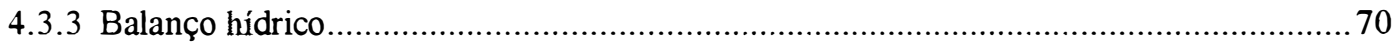

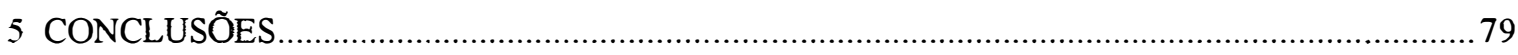

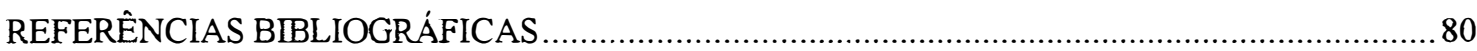




\title{
DISPONIBILIDADE DE ÁGUA NO SOLO PARA PORTA-ENXERTOS DE CITROS EM ECOSSISTEMA DE TABULEIRO COSTEIRO
}

\author{
Autor: FERNANDO LUIS DULTRA CINTRA \\ Orientador: PAULO LEONEL LIBARDI
}

\section{RESUMO}

Apesar do grande potencial dos tabuleiros costeiros para exploração agrícola, relacionado à topografia favorável à mecanização e proximidade de grandes centros consumidores, a má distribuição das chuvas associada aos horizontes coesos situados próximos à superficie e presentes em muitas classes de solo deste ecossistema, promove, com frequência, sérios problemas no suprimento de água para as plantas. No caso dos citros, principal atividade agrícola dos tabuleiros do Estado de Sergipe o déficit hídrico ocorre nos períodos de maior demanda hídrica das plantas diminuindo a potencialidade desta região para a citricultura. Este trabalho foi realizado com o objetivo de produzir informações, envolvendo o maior número possível de fatores, capazes de gerar tecnologias ajustadas ao ecossistema com aproveitamento máximo dos recursos disponiveis, principalmente, os relacionados à disponibilidade de água para as plantas. Para isto foram avaliados em experimento conduzido no Campo Experimental de Umbaúba, Estado de Sergipe, EMBRAPA Tabuleiros Costeiros, o sistema radicular de cinco porta-enxertos de citros em combinação com a copa de laranjeira Pêra (Citrus sinensis (L.) Osbeck), características do solo com efeito direto na alteração dos fatores fisicos de crescimento e alguns dos principais processos envolvidos na redistribuição de água no solo (drenagem interna, ascenção capilar, evapotranspiração e variação de armazenagem). Os resultados obtidos permitem concluir que apesar de restringir o sistema radicular a um pequeno volume de solo próximo à superficie, a camada coesa exerce ação benéfica, neste ecossistema, por atuar como barreira fisica às perdas de água e por permitir a formação de uma zona de armazenamento a qual supre, em parte, a grande demanda das plantas no início da estação seca. Com relação aos 
porta-enxertos o Limão Cravo (Citrus limonia Osbeck) pode ser considerado o material melhor adaptado ao ecossistema estudado por apresentar o menor volume de raizes, característica que proporciona o esgotamento mais lento das reserva de água do solo, e as menores taxas de evapotranspiração nos períodos de grande demanda hídrica. No outro extremo, apresentando as maiores taxas de evapotranspiração diária no final da estação chuvosa e início da estação seca além do sistema radicular mais volumoso, situou-se a Tangerina Cleópatra (Citrus reshni Hort. ex Tan) a qual, por estas características, pode ser considerado, entre os porta-enxertos avaliados, o de menor adaptação. 


\title{
SOIL-WATER AVAILABILITY TO CITRUS ROOTSTOCKS IN "TABULEIRO COSTEIRO" ECOSYSTEM.
}

\author{
Author: FERNANDO LUIS DULTRA CINTRA \\ Adviser: PAULO LEONEL LIBARDI
}

\section{SUMMARY}

In spite of the great potential of "tabuleiros costeiros" for agricultural exploration in terms of favourable relief to mechanization and neighbourhood of the big consumer centres, the bad rain distribution together with hardened soil horizons near the soil surface in many soil classes of this ecosystem, often promote serious problems in the water supply to the plants. In the case of citrus, main agricultural activity in "tabuleiros" of State of Sergipe (Brazil), the water deficit occur in periods of greater water demand by the plants, hence decreasing the potentiality of this regions for citrus cropping. This work was carried out with the objective of producing information, involving as many factors as possible, that leads to the generation of technologies fitted to the ecosystem and taking the maximum advantage of the available resources, mainly those related to water availability to plants. For this, the root system of five citrus rootstocks in combination with a crown of "laranja Pêra" (Citrus sianensis, (L). Osbeck) were evaluated together with soil characteristics affecting diretctly growing physical factors (soil-water potential soil aeration and soil mechanical resistence to the root penetration) and some of the main processes related to soil-water redistribution (internal drainage, capillary rise, evapotranspiration and soil-water storage variation). According to the results, it could be concluded that in spite of the hardened layer to limit the root system to a small volume near the soil surface, it exerts an important benefic action in this ecosystem, because it acts as a physical barrier to water losses and gives rise to a water storage zone which supplies, in part, the great water demand by plants at the beginning of the drying season. With respect to the rootstocks, the "Limão Cravo" (Citrus limonia, Osbeck) can be considered the best adapted to the studied ecosystem because it presents the smaller 
volume of roots, leading to a slower exhaustion of the soil water reservoir and to a lower evapotranspiration rate during the periods of great water demand. At the other extreme, presenting greater volume roots and higher daily evapotranspiration rates at the end of the rainy season is the "Tangerina Cléopatra", (Citrus reshni, Hort. ex Tan) which therefore, can be considered, among the rootstocks evaluated that of lesser adaptation. 


\section{INTRODUÇÃO}

Os baixos platôs costeiros, também denominados tabuleiros costeiros, são superficies relacionadas aos sedimentos do Grupo Barreiras-Terciário Superior, assentadas sobre embasamento cristalino e apresentando altitude entre 30 e $150 \mathrm{~m}$. Sua morfologia está relacionada ao nivelamento do terreno ocorrido na mais recente era cenozóica cujos processos de formação consistiram, em parte, da redução das rochas cristalinas pela ação do intemperismo e erosão e, em parte, pela acumulação de produtos clásticos da erosão. Em certos trechos da costa nordestina essas superficies, que ocupam cerca de 8,5 milhões de hectares, são cortadas em falésias abruptas formando extensos planaltos escarpados.

A importância social e econômica desse ecossistema nos estados da Bahia, Sergipe, Alagoas, Pernambuco, Paraíba, Rio Grande do Norte e Ceará é refletida pelas grandes concentrações urbanas, pela diversidade de explorações agrícolas com grande potencialidade para produção de alimentos, pela ampla infra-estrutura de transporte rodoviário e de terminais marítimos para escoamento da produção e por abrigar grande parte da mata atlântica ainda existente no País. Segundo dados constantes

do plano diretor da Empresa Brasileira de Pesquisa Agropecuária-EMBRAPA/Centro de Pesquisa Agropecuário dos Tabuleiros Costeiros-CPATC, os tabuleiros costeiros contribuem com $26,4 \%$ e $38 \%$ do PIB gerado pelas culturas temporárias e permanentes, respectivamente, nesses Estados. Apesar dessa importância e da existência de grande mercado potencial e demanda reprimida por produtos agrícolas, a atividade agropecuária tem sido, via de regra, inviabilizada pelas baixas produções e alta relação custo/beneficio proporcionada pelas culturas. 
O meio fisico representado, principalmente, pelas camadas coesas e o clima representado pela má distribuição das chuvas, as quais estão concentradas em cerca de $80 \%$ num período de seis meses contínuos (entre os meses de abril e setembro) são os principais fatores responsáveis pelas baixas produtividades das espécies cultivadas nesta unidade de paisagem. A gênese das camadas coesas, geralmente posicionadas nos horizontes de transição $\mathrm{AB}$ ou $\mathrm{BA}$ podendo, no entanto, atingir os horizontes diagnóstico $\mathrm{Bt}$ e $\mathrm{Bw}$, tem sido associada a vários processos, entre os quais, a perda de argila das camadas superficiais do solo para as camadas subjacentes, processo este denominado argiluviação, à presença de compostos orgânicos pouco polimerizados, à forte instabilidade estrutural, à presença de sílica secundária, ferro e argila dispersa nos microporos e ao adensamento por dessecação resultante da alteração da estrutura do solo pela alternância de ciclos de umedecimento e secagem. É mais provável, no entanto, que esses processos ocorram simultâneamente e que a intensidade de formação das camadas coesas esteja relacionada às variações climáticas e morfopedológicas existentes nas diferentes unidades geoambientais que compõem a unidade de paisagem dos tabuleiros costeiros.

A presença de camadas de impedimento associadas ao regime climático predominante nos tabuleiros atua como contraponto a algumas das principais potencialidades desse ecossistema como a elevada profundidade dos solos e a topografia plana a suave ondulada. Tal fato ocorre devido à redução que causa na profundidade efetiva dos solos e a formação de zonas temporárias de encharcamento e ressecamento durante as estações chuvosa e seca, respectivamente. Além disso, essas camadas interferem nos fatores fisicos do solo que atuam no desenvolvimento das plantas tais como, potencial de água, aeração e resistência do solo à penetração das raízes promovendo alterações na quantidade de água e ar absorvida e respirada pelas plantas e no fluxo desses componentes no solo. Essas alterações dependem, não apenas do volume de água e ar existentes no solo, ou do volume total e configuração do sistema radicular, mas também, da aptidão do solo em transmitir água às raízes com a rapidez necessária para atender as exigências transpiratórias da planta e do meio ambiente. No estado de 
Sergipe esses problemas afetam de forma expressiva a região produtora de citros cuja exploração, conduzida geralmente em condições de sequeiro, representa uma de suas mais importantes atividades agrícolas.

Como os porta-enxertos, em geral, diferenciam-se quanto à tolerância aos estresses ambientais e aos fatores de solo eles surgem como uma das alternativas de manejo da cultura para a minimização desses problemas. A característica de adaptação dos diferentes materiais está, principalmente, relacionada ao volume total das raizes, à configuração do sistema radicular e à sua distribuição lateral e em profundidade no solo devido à importância da sua participação na absorção de água e nutrientes, no processo respiratório e na possibilidade de rompimento de camadas adensadas.

Todo esse conjunto de fatores faz com que o manejo das culturas nesses solos, especialmente as de ciclo longo, a exemplo dos citros, seja criteriosamente planejado sendo para isso necessário investir em pesquisas, como a aqui apresentada, que tem como objetivo a produção de informações capazes de minimizar os problemas causados pelos horizontes coesos e seus reflexos sobre a dinâmica da água em solo de tabuleiro, a fim de solucionar os problemas relacionados ao seu conteúdo e movimento. É esperado que a utilização de tecnologias, geradas ou adaptadas, tendo como base conhecimentos obtidos no próprio ecossistema e no tempo real, permita o máximo aproveitamento dos recursos disponíveis, possibilitando uma intervenção eficaz, tanto no aspecto produtivo quanto na redução dos danos ao meio ambiente. Com base nesse pressuposto foi delineada a hipótese de trabalho na qual assume-se que o regime hídrico, caracterizado por longos períodos de estiagem, e a presença de camadas coesas, próximas à superficie do solo, constituem fatores restritivos ao movimento de água no solo e ao desenvolvimento do sistema radicular de porta-enxertos de citros em ecossistema de tabuleiro costeiro. 


\section{REVISĀO DE LITERATURA}

\subsection{Tabuleiros costeiros}

$\mathrm{Na}$ faixa sedimentar costeira do Brasil é possível distinguir quatro unidades de paisagem: baixada litorânea, superficies terciárias dos baixos platôs costeiros, também denominadas tabuleiros costeiros ou simplesmente tabuleiros, superficies terciárias muito dissecadas e bacia cretácia (Empresa Brasileira de Pesquisa Agropecuária-EMBRAPA/Superintendência de desenvolvimento do Nordeste-SUDENE, 1975). O objeto do presente estudo restringe-se às unidades de paisagem dos tabuleiros e as superficies terciárias muito dissecadas onde ocorrem tabuleiros como inclusões residuais. A importância social e econômica deste ecossistema é refletida pelas grandes concentrações urbanas, infraestrutura de transporte e grande diversidade agrícola. Segundo o Plano Diretor da EMBRAPA/Centro de Pesquisa Agropecuária dos Tabuleiros Costeiros-CPATC (1994), os tabuleiros abrangidos pelos Estados da Bahia, Sergipe, Alagoas, Pernambuco, Paraíba, Rio Grande do Norte e Ceará, contribuem com 26,4 e $38,2 \%$ do PIB gerado pelas culturas temporárias e permanentes, respectivamente.

Antes porém de abordar parte do que existe na literatura correlata sobre o tema tabuleiro, é necessário definir os termos unidade de paisagem e unidade geoambiental, os quais serão citados com frequência em todo o texto. De acordo com o zoneamento agroecológico do Nordeste realizado pela EMBRAPA/Centro de Pesquisa Agropecuária do Trópico Semi Árido-CPATSA/Centro de Pesquisa de Solo-CNPS, Silva et al. (1993), unidade geoambiental é definida "como uma entidade espacial, na qual o substrato, a vegetação natural, o modelado, a natureza e a distribuição dos solos, em 
função da topografia, constituem um conjunto homogêneo, cuja variabilidade é mínima, de acordo com a escala cartográfica". As unidades geoambientais agrupadas com base nas características morfoestruturais e/ou geomorfológicas e/ou geográficas, compõem as unidades de paisagem, categoria esta, em que se enquadram os tabuleiros costeiros. Algumas variações, no entanto, são utilizadas como a apresentada no plano diretor da EMBRAPA/CPATC (1994) na qual, os tabuleiros são subdivididos em quatro subregiões baseadas em algumas similaridades específicas.

A unidade de paisagem dos tabuleiros é composta por superfícies em forma de mesetas cujos topos apresentam-se planos ou com suaves ondulações e têm origem nos sedimentos do Grupo Barreiras-Terciário Superior, depositados sobre material do cretácio ou sobre embasamento cristalino. No estado de Sergipe em cujos tabuleiros este trabalho foi realizado, os mesmos estão assentados, mais frequentemente, sobre materiais do cretácio (EMBRAPA/SUDENE, 1975). Segundo Haynes (1970) os aspectos morfológicos relacionados com o nivelamento do terreno, ocorrido na mais recente era cenozóica, permitem identificar espessuras variadas que estão de acordo com as coberturas sedimentares do Grupo Barreiras. Enfatiza ainda que os processos de nivelamento que ocorreram ao final dessa era consistiram, em parte, da redução das rochas cristalinas pela ação do intemperismo e, em parte, pela acumulação dos produtos da erosão, ambas no mesmo nível topográfico.

A ocupação humana, combinada à friabilidade litológica favorece a aceleração dos processos morfodinâmicos, nesta unidade de paisagem, contribuindo para o agravamento da lixiviação e movimento de massas nos solos imprimindo, em alguns trechos da paisagem caráter bastante instável. Esta instabilidade, facilmente perceptível através do desenvolvimento de ravinamentos e deslizamentos nas encostas mais íngremes (Brasil.Ministério das Minas e Energia, 1983), se traduz também pelo desaparecimento de espécies vegetais e pela intensificação do processo erosivo. A este respeito Silva (1991) ressalta a ação do desmatamento sobre o quase total desaparecimento de várias espécies vegetais nobres da Mata Atlântica nos tabuleiros costeiros do extremo sul da 
Bahia, como também, sobre a degradação da camada superficial do solo, intensificação do adensamento e perdas de solo por erosão. É provável que na sua origem, os tabuleiros costeiros tenham sido ocupados por florestas tropicais subperenifólias, vegetação típica da Mata Atlântica e por vegetação de cerrado, nos solos mais arenosos.

A precipitação média anual nesse ecossistema apresenta variações que vão de $500 \mathrm{~mm}$ nas regiões mais secas, a exemplo de parte dos tabuleiros do Rio Grande do Norte até $1500 \mathrm{~mm}$ no extremo sul da Bahia. A sazonalidade, no entanto, é muito forte estando as chuvas concentradas, em torno de $80 \%$, em um período contínuo de 5 a 6 meses. As temperaturas médias anuais situam-se ao redor de $26^{\circ} \mathrm{C}$ havendo pouca variação entre as médias do mês mais quente e mais frio. $\mathrm{Na}$ unidade geoambiental em que se encontra o estado de Sergipe, a precipitação média anual fica em torno de 1200 mm anuais distribuída entre os meses de março a setembro (EMBRAPA/CPATC, 1994).

Quanto à distribuição dos solos, os de maior expressão são os Latossolos Amarelos, Podzólicos Amarelos e Acinzentados, Areias Quartzosas e Podzóis. Uma característica marcante em muitos desses solos é a presença de uma camada coesa, com espessura média entre 0,2 $\mathrm{m}$ e $0,6 \mathrm{~m}$, geralmente localizada nos horizontes de transição $\mathrm{AB}$ ou $\mathrm{BA}$, podendo, no entanto, atingir os horizontes $\mathrm{Bw}$ ou $\mathrm{Bt}$. A presença dessas camadas endurecidas tem como consequências o impedimento à circulação de água e ar no solo e à penetração de raízes e a formação sazonal de lençol de água suspenso gerando desoxigenação temporária nos horizontes superficiais (Jacomine, 1996; Reunião Técnica sobre Solos Coesos dos Tabuleiros Costeiros, 1996a).

O meio físico representado, principalmente, pelas camadas coesas e o regime climático caracterizado pela alta concentração das chuvas e presença de período prolongado de seca, são os principais responsáveis pelos problemas associados à exploração agropecuária nesse ecossistema. Historicamente, no entanto, esses problemas tem sido mascarados, ao longo do tempo, em virtude da paisagem aparentemente favorável ao uso agrícola como relevo adequado à mecanização, volume elevado de precipitação pluvial total e grande profundidade do solo. Nos tabuleiros onde coexistem 
camadas coesas e longos períodos de déficit hídrico, as vantagens mencionadas deixam de existir devido não só ao impedimento à penetração das raízes e consequente redução da profundidade efetiva do solo, como também, à formação de zonas temporárias de encharcamento durante a estação chuvosa. Nestas circunstâncias, os solos ficam altamente vulneráveis ao regime climático, passando do estágio excessivamente úmido, no período chuvoso, para excessivamente seco quando as chuvas escasseiam, submetendo as raízes das plantas, em geral superficializadas, a condições de má aeração ou de completa ausência de umidade.

A formação dessas camadas tem sua origem atribuída a causas genéticas, ponto comum entre os pesquisadores que estudam este tema e está associada a processos diversos entre os quais, a translocação de consideráveis porções de argila das camadas superficiais para as subjacentes, processo este denominado argiluviação, (Ribeiro, 1991) à ação de compostos húmicos pouco polimerizados os quais geram degradação dos minerais argilosos e migração de sílica, alumínio e ferro (Ribeiro, 1993) e, à alternância de ciclos de umedecimento e secagem promovendo o adensamento por dessecação com transformações laterais condicionadas pela dinâmica dos fluxos de água lateral e basal (Moniz, 1996). Pode estar associado a este último processo, a desidratação dos agentes cimentantes, com a consolidação da argila no período de seca, seguida da implosão dos agregados devido ao aumento da pressão interna de ar, quando o solo umedece (Harris et al., citado por Freitas e Blancaneaux, 1990). Esse último processo faz parte da gênese de diversos solos e não foi diretamente relacionado, pelos autores, à gênese dos solos de tabuleiro.

A dinâmica da água no solo, vital para o crescimento e desenvolvimento das espécies vegetais, é um dos principais fatores afetados pela presença de camadas coesas nos solos de tabuleiro na medida em que impõe grandes alterações no fluxo de água e ar e, consequentemente, nos fatores fisicos de crescimento: potencial de água no solo, aeração, temperatura e resistência à penetração de raizes. Este é um dos motivos pelo qual este tema consta como uma das principais linhas de pesquisa no 
documento de compatibilização das propostas de pesquisa oriundo da Reunião Técnica sobre Solos Coesos dos tabuleiros Costeiros (1996b).

\subsection{Porta-enxertos de citros}

A citricultura tem sido uma das principais opções de atividade agrícola no ecossistema dos tabuleiros costeiros do Nordeste em virtude, principalmente, da topografia predominantemente plana dos solos, à expansão da indústria de sucos no País e ao regime climático que, em certos aspectos, contribui para o bom desenvolvimento da cultura nessa região. Apesar dessa importância, verificada com mais intensidade, na unidade geoambiental que inclui os tabuleiros do norte do estado da Bahia e de todo o estado de Sergipe, não se tem obtido, via de regra, produtividades compatíveis com os investimentos aplicados à agricultura. As restrições estão, em grande parte, associadas às alterações impostas aos fatores fisicos de crescimento das plantas pelas camadas coesas e longos períodos de déficits hídricos, já abordadas no capítulo 2.1.

Segundo Pompeu Júnior (1991) a enxertia é o método mais utilizado na propagação dos citros por proporcionar às laranjeiras maior uniformidade e precocidade da produção e, como consequência, melhoria na produtividade e qualidade dos frutos. No entanto, para se obter boa resposta do pomar é necessário que o mesmo esteja implantado em ecossistema apropriado, que os tratos culturais adotados sejam adequados e que o relacionamento entre a copa e o porta-enxerto seja o mais harmônico possível. Segundo Tuzcu et al. (1981) é preciso ter em mente que o interesse por um porta-enxerto advém de um conjunto de características desejáveis, tais como: resistência às principais doenças parasitárias, tolerância às doenças de vírus, resistência ao frio em regiões subtropicais e à capacidade de imprimir rendimentos elevados e boa qualidade de frutos às laranjeiras de tal forma que haja o melhor aproveitamento dos recursos disponíveis. As características químicas e fisicas do solo, a presença de zonas de impedimento próximas à superficie, a adequação das condições climáticas e o conhecimento das taxas de crescimento e extensão do sistema radicular e da sua distribuição no solo, são também, de 
acordo com Castle et al. (1989), fatores que devem ser considerados quando da seleção de porta-enxertos de citros.

Já na década de 50, os pesquisadores envolvidos com a citricultura, tinham a preocupação de encontrar porta-enxertos ajustados às condicões ambientais. Ford (1954) conduziu trabalho com diferentes porta-enxertos em solo arenoso e profundo encontrando que o Limão Rugoso e a Tangerina Cleópatra aprofundavam o sistema radicular além de $1,20 \mathrm{~m}$, fato este não observado nos outros materiais. Hagin et al. (1965) avaliaram dois porta-enxertos quanto à adaptação a cinco tipos de solo e encontraram que as diferenças texturais e seus efeitos sobre a aeração do solo afetavam menos o Citrus aurantium do que o Citrus limettoides. Castle \& Krezdorn (1973) obtiveram correlação positiva entre altura de porta-enxertos e profundidade atingida pelas raizes e observaram que em torno de $50 \%$ do sistema radicular das plantas mais altas atingiram profundidade superior a $76 \mathrm{~cm}$. Concluíram que o melhor acesso das plantas às reservas hídricas do solo estava relacionado à sua maior altura. Castle (1980) enfatiza a adaptação do limão rugoso da Flórida a solos profundos com baixa capacidade de retenção de água, enquanto que, Pace \& Araújo (1986) ao estudarem o comportamento de diferentes porta-enxertos em solos podzolizados, com presença de camada adensada no horizonte de transição, observaram que todos os materiais se comportaram da mesma maneira em relação ao impedimento à penetração das radicelas. Sakovich (1986) vai mais além ampliando esta preocupação às espécies frutíferas em geral e atribue à densidade da camada superficial e à presença de teores adequados de ar e água no solo, juntamente com o potencial genético das plantas, o melhor ou pior desempenho das espécies frutíferas.

Os estudos relacionados à influência do meio ambiente sobre a cultura de citros devem ser direcionados, principalmente, para avaliação dos efeitos dos fatores climáticos sobre a transpiração e uso de água pelas plantas e sobre o regime hídrico do solo (Reuther, 1973). Esta prioridade, que se aproxima bastante das necessidades observadas na unidade de paisagem dos tabuleiros costeiros, está associada, segundo este 
autor, à forte relação existente entre disponibilidade de água no solo com a produtividade e vigor das plantas e a qualidade dos frutos. Enfatiza ainda que a distribuição anual das chuvas e sua quantidade total, que deve se situar entre 1000 e $2000 \mathrm{~mm}$, é um dos pré requisitos para a adaptação dos citros nas diferentes regiões climáticas. Esta é também a posição de Oliveira (1991) o qual acrescenta que por ser o citros uma espécie perenifólia, requer niveis contínuos de umidade no solo além de condições adequadas de drenagem, porosidade e permeabilidade. Ortolani et al. (1991), no entanto, afirmam que as necessidades hídricas dos citros variam conforme a distribuição espacial e temporal das condições climáticas, dos fatores relacionados ao manejo do pomar da combinação enxerto/porta-enxerto e das características hídricas do solo.

Como o suprimento de água para as culturas se constitui num dos principais fatores limitantes à produção e, a exploração de citros é desenvolvida, em sua grande maioria sob condições de sequeiro, situação esta que representa a quase totalidade dos pomares implantados nos tabuleiros costeiros, tem sido uma constante, nas diversas regiões produtoras do mundo, a busca de alternativas de baixo custo capazes de permitir o melhor uso dos recursos naturais. Uma das alternativas mais utilizadas tem sido o uso de porta-enxertos adaptados e compatíveis com as variedades utilizadas comercialmente devido às diferenças que apresentam entre si as quais, tem grande relevância no comportamento das plantas nos diferentes ecossistemas. Essa pressuposição é enfatizada por Castle et al. (1989), os quais afirmam que os porta-enxertos comumente utilizados na cultura de citros não são igualmente tolerantes à seca e que, grande parte das diferenças observadas ocorrem devido à variação na quantidade de radicelas e na sua distribuição horizontal e vertical.

São vários os fatores relacionados à maior ou menor resistência dos porta-enxertos de citros à seca. Segundo Shalhevet \& Levi (1990) apesar dessa espécie ser adaptada às regiões tropicais e subtropicais, suas plantas apresentam algumas características xerofiticas tais como folhas rígidas, cutícula espessa e redução da condutância estomática quando submetidas a estresses de umidade. A economia de água 
na planta promovida pela redução na condutância estomática promove, segundo Castro (1995), redução na perda de água por transpiração e aumento do potencial hídrico foliar. Com o fechamento dos estômatos sob alta demanda evaporativa, as plantas cítricas reduzem o consumo de água, minimizando o estresse a que seriam submetidas nos periodos de estiagem. É esse mecanismo adaptativo que segundo este autor, leva as plantas cítricas a sobreviver em ambientes com baixos teores de água e, ainda assim, ser capaz de transpirar e fotossintetizar quando as condições ambientais são muito severas. Sob condições extremas, no entanto, ocorrem muitas alterações químicas, principalmente hormonais, como a perda das reservas energéticas, processo iniciado no momento do fechamento dos estômatos e que representa a alteração mais importante. Quando isso ocorre há aumento acentuado no potencial osmótico repercutindo na morte das folhas, ramos e radicelas (Lima, 1995).

A taxa de crescimento e o volume total das raízes dos porta-enxertos, como também a função e distribuição do sistema radicular no solo, têm sido alguns dos pontos mais investigados na cultura dos citros na tentativa de encontrar materiais adaptados aos diferentes ecossistemas. Isto ocorre devido, não só, à estreita relação deste órgão da planta com a absorção de água e nutrientes, como também, à sua participação no processo respiratório. Kolesnikov (1971) é enfático ao afirmar que a configuração do sistema radicular de uma mesma variedade frutífera, sob condições similares de manejo, diferem rigorosamente com o porta-enxerto utilizado. Foi, provavelmente, com base em pressuposição como essa que Castle \& Krezdorn (1977), avaliaram a eficiência de quatro porta-enxertos de citros quanto à extração de água no solo, concluindo que as maiores perdas ocorreram, inicialmente, na superficie do solo com contribuição crescente das raízes mais profundas à medida que a água das camadas superficiais era esgotada. Resultados obtidos por Avilan et al. (1979) também ressaltam a importância do aprofundamento do sistema radicular dos porta-enxertos no suprimento de água. Ao avaliarem o Citrus aurantium L e o Citrus sinensis (L) Osbeck, obtiveram melhor resposta do primeiro à variação de umidade do solo em virtude do maior aprofundamento de suas raizes. Tuzcu et al. (1981) compararam em uma mesma situação pedoclimática 
dez porta-enxertos quanto ao comportamento do sistema radicular tendo a precaução de utilizar pés-franco para evitar que os sistemas aéreos, geneticamente diferentes, impedissem à planta expressar todo seu potencial intrínseco. Os resultados obtidos demonstraram que o sistema radicular da laranja azeda atingiu as maiores profundidades, sendo esta característica, segundo os autores, indicadora da tolerância deste portaenxerto às condições de má aeração. Além dos estudos relacionados à determinação do volume total e distribuição das raízes no solo, tem havido também, a preocupação de identificar as principais zonas de concentração de radicelas e sua relação com a absorção de água e nutrientes. Nesse sentido o trabalho conduzido por Hassan (1984) permitiu identificar diferenças entre porta-enxertos de citros, tanto quanto à habilidade de aprofundamento das raízes quanto à existência de forte relação entre ramificações do sistema radicular e absorção de nutrientes.

\subsection{Sistema radicular}

A importância do sistema radicular sobre o desenvolvimento, crescimento e frutificação das espécies vegetais é um fato incontestável por ser este órgão a sede de alguns dos principais processos metabólicos que atuam no funcionamento geral da planta. Entre as inúmeras funções do sistema radicular Kolesnikov (1971) destaca: a) a absorção de água e nutrientes, produção de aminoácidos, proteínas, hormônios e outras substâncias orgânicas, b) excreção de açúcares, ácidos orgânicos e compostos minerais de fósforo e potássio que contribuem para a dissolução de substâncias minerais e para o desenvolvimento de microorganismos na rizosfera, c) influência ativa na parte sólida do solo através da formação de canais pelo deslocamento das frações minerais e orgânicas, d) influência ativa na passagem de parte dos íons absorvidos na solução suprindo a parte aérea da planta com os produtos da sua

conversão, e) interação com microorganismos e outros organismos da rizosfera e, f) sustentação da planta ao solo.

Apesar da similaridade relativa existente entre o sistema radicular das espécies frutíferas perenes e arbóreas, a distribuição horizontal e vertical das raízes 
depende de vários fatores entre os quais: idade da planta, variedade, origem da raiz se por semente ou enxerto, tipo de porta-enxerto, tipo de solo e manejo adotado no pomar. A maioria das raízes distribue-se horizontalmente em torno de $2 \mathrm{~m}$ e a maior concentração de radicelas situa-se nos primeiros 0,5 m de profundidade (Kolesnikov, 1971; Atkinson, 1980). Thinker (1981) enfatiza, no entanto, que apesar da importância exercida pelos fatores ambientais, como teor de água no solo e concentração de nutrientes na zona do sistema radicular, o componente genético tem grande efeito no aprofundamento ou superficialização do sistema radicular. Nye \& Thinker (1977) acreditam que certas orientações das raizes são resultantes do efeito do geotropismo, da estrutura do solo e das fissuras por acaso existentes. Sob condições extremas, a exemplo da presença de camadas adensadas, os autores advertem que a configuração do sistema radicular pode ser totalmente alterada em relação à que apresentaria sob condições de solo homogêneo. Para a cultura de citros, em solos bem drenados, tem sido observado que o crescimento das raizes pode atingir entre 1,2 e 1,5 m de profundidade porém a maior concentração situa-se entre 0,6 e 0,9 m (Jones \& Embleton, 1973; Shalhevet \& Levy, 1990).

Em geral, os problemas relacionados com a absorção de água pelas plantas podem ser classificados em três tipos: os que ocorrem na interface solo-raiz, ao nivel do parênquima cortical, onde o movimento da solução é função do gradiente de pressão osmótica, os relacionados à retenção de água pelo solo e que dependem, principalmente, do potencial mátrico e, os relacionados à planta como um todo que envolvem o movimento da água do solo até as folhas e inclui todos os fenômenos originados na interface solo-raiz no endoderma e nas partes aéreas através da regulação estomática (Chopart, 1980). Com a cultura de citros Jones \& Embleton (1973) verificaram que, pelo fato das raizes dessa espécie serem funcionais por todo o ano $\mathrm{e}$ durante vários anos, o sistema radicular fica, em geral, muito vulnerável às alterações do meio fisico e às mudanças climáticas. Uma das principais restrições impostas ao sistema radicular dos citros, está relacionado à resistência mecânica que o solo oferece ao crescimento das raizes. Esse impedimento é, no entanto, frequentemente transitório e depende, em grande parte, do conteúdo de água existente na camada adensada 
(Taylor, 1974). Da mesma forma, sob condições de campo, nem todas as partes das raízes são igualmente expostas ao adensamento e o efeito compensatório das partes não prejudicadas, poderá não comprometer o sistema radicular da planta com um todo (Unger \& Kaspar, 1994). Além disso, segundo Wiersum (1957), a influência do tamanho do poro ou do diâmetro da raiz sobre a penetração do sistema radicular em camadas adensadas só existirá se houver completa rigidez das partículas sólidas, caso contrário, as raízes forçam sua passagem por entre as partículas minerais.

O potencial de crescimento do sistema radicular e seu funcionamento, especialmente em condições de sequeiro, é determinado, segundo Callot et al. (1982), pelas características físico-químicas do solo e por todos os fatores ambientais que interferem no metabolismo das raízes. Se os solos são profundos porém apresentam camadas de impedimento, são pobres em nutrientes e o suprimento de água é irregular nas diversas fases de crescimento, o estoque de água e nutrientes realmente disponível para as plantas passa a ser regulado, em grande parte, pelas características do sistema radicular da espécie cultivada. Esta situação é frequentemente observada nos tabuleiros costeiros em cuja maioria dos solos ocorrem zonas coesas, em geral, restritivas ao crescimento das raízes durante grande parte do ano. O horizonte coeso típico, existente nas unidades de solo dos tabuleiros costeiros é definido por Ribeiro (1991) como um "horizonte duro ou pouco friável, sem organização estrutural, quebrando-se em fragmentos angulosos e com raras raízes, geralmente mortas. Em alguns pontos pode-se observar uma organização estrutural do tipo poliédrica associada a pequenas concentrações de material orgânico e alguma porosidade do tipo biológica. Apresenta-se muito duro e compacto e as raizes que penetram no horizonte sobreposto tendem a se horizontalizar". A ocorrência desta camada atuando isoladamente ou em associação com o regime climático, pode ser considerada como um dos grandes entraves à utilização agrícola dos solos nesse ecossistema.

Entre as implicações do meio físico que atuam sobre o desenvolvimento do sistema radicular em solos de tabuleiro, destacam-se além do impedimento mecânico, 
a má oxigenação e a baixa disponibilidade de água para as plantas em algumas épocas do ano. A alteração desses fatores fisicos de crescimento estão direta ou indiretamente relacionados com a presença de camadas coesas. Eavis (1972) ressalta que o impedimento mecânico é um dos principais fatores restritivos ao crescimento do sistema radicular e que a resistência à penetração das raizes é tanto maior quanto maior for a densidade do solo e o potencial mátrico. Além do efeito direto sobre o crescimento, quando submetidas a densidades muito elevadas, as células das raízes deixam de alongar normalmente, engrossando e atingindo espessuras que podem chegar a três vezes o seu diâmetro normal (Pearson, 1966). Apesar da resistência mecânica ser o fator frequentemente responsabilizado pela restrição à penetração das raizes em camadas adensadas, é muito dificil, segundo Wiersum (1957), separar os seus efeitos dos exercidos pela elevada densidade do solo, excesso de umidade e má aeração.

A afirmativa de Jones \& Embleton (1973) de que "nenhuma característica é mais importante nos solos cultivados com citros do que uma boa drenagem pois, sem uma drenagem satisfatória a acumulação de água livre na zona do sistema radicular resulta em baixa aeração e prejuízos às raízes", nos leva ao segundo fator fisico de crescimento com atuação relevante sobre o sistema radicular desta cultura em muitas unidades geoambientais dos tabuleiro: a aeração do solo. As consequências diretas do adensamento são, quase sempre, inseparáveis dos seus efeitos indiretos na medida em que, muitas vezes, as raizes são impedidas de penetrar uma camada fracamente adensada devido ao seu elevado conteúdo de água. Nesse caso, a aeração inadequada do meio passa a exercer maior influência sobre o sistema radicular do que a resistência que o solo oferece à sua penetração. Inversamente, quando o solo seca, a resistência mecânica das camadas adensadas aumenta acentuadamente e o impedimento fisico à penetração das raizes torna-se mais limitante do que a concentração e a taxa de difusão de oxigênio (Pearson, 1966).

Trabalho desenvolvido por Taylor et al. (1964) ilustra bem a influência da má aeração sobre o desenvolvimento das raizes: durante um período de seca, foi 
observado que a resistência do solo foi a principal causa da deformação sofrida pelo sistema radicular, no entanto, quando a umidade situava-se próxima à capacidade de campo as raízes penetravam normalmente e, à medida que o teor de água se aproximava da saturação poucas raizes penetravam as zonas adensadas. Com base nessas informações, os autores concluíram que o manejo da água da chuva ou da irrigação, pode permitir a convivência com uma camada adensada na medida em que é possível modificar sua condição de restritiva, para não restritiva, ao crescimento das raízes.

Quanto à influência do potencial da água no solo sobre o crescimento das raízes, Pearson (1966) observa que a tensão de água no solo parece ter mais efeito sobre a absorção do que sobre a elongação das raízes a qual, não é tão afetada sob elevadas tensões como o é sob condições de excesso de umidade. Esta afirmativa contrasta com as observações de Bevington \& Castle (1985) os quais observaram que o sistema radicular de mudas de citros foi muito afetado quando o potencial mátrico foi elevado a 0,05 MPa. Por outro lado Forsyth (1967) ressalta que cada cultura tem sua habilidade própria de extrair água do solo o qual, por sua vez, tem habilidade específica para fornecer água a várias tensões. $\mathrm{O}$ ajuste entre estas duas características determinará, segundo o autor, a água disponível no solo capaz de proporcionar rendimento satisfatório a uma dada cultura.

O efeito da interação entre os fatores físicos de crescimento sobre o desenvolvimento do sistema radicular, em solos com camadas adensadas, representado pela má aeração, impedimento mecânico e potencial de água no solo, à exceção da temperatura do solo, sobre a qual não há evidências de efeito marcante no ecossistema dos tabuleiros, é bem resumido por Russel (1981). Este autor destaca que o estresse hídrico imposto pelo solo às raízes das plantas, durante uma estação seca, pode não ser o mesmo em toda a extensão do sistema radicular: o estresse mais severo próximo à superficie do solo pelo efeito do baixo potencial de água pode atuar conjuntamente com a falta de oxigênio sentida nas camadas profundas e com o impedimento mecânico na camada adensada. 
Apesar dos avanços obtidos nos estudos envolvendo a interação sistema radicular, água e solo, existem ainda grandes dificuldades em se obter uma definição fisica exata dos processos de extração da água pelas raízes. Estas dificuldades, descritas por Hillel (1970), são devido ao fato das raízes crescerem em planos, direções e espaçamentos diferentes e, principalmente, das dificuldades encontradas nos métodos experimentais em uso em medir gradientes muito pequenos e os fluxos de água nas imediações das raízes. A tensão da água no solo que está em contacto com a raiz pode ser muito maior do que a tensão média medida pelos métodos convencionais que envolvem um volume de solo muito grande. Muitos desses problemas serão abordados a seguir no capítulo que trata das relações água/solo.

\subsection{Movimento de água no solo}

O regime hídrico do solo e a disponibilidade de água para as plantas é objeto de estudo sempre presente quando estão envolvidos produção e produtividade de culturas e adaptação de espécies vegetais ao meio ambiente. Em muitas unidades geoambientais dos tabuleiros costeiros este tema assume relevância especial devido aos problemas de ordem fisica e climática existentes nesse ecossistema que tornam o movimento da água nos solos um assunto bastante complexo. Vale lembrar as observações feitas por Hillel (1970) de que a quantidade de água absorvida pelas plantas não depende apenas do conteúdo ou do potencial total da água no solo, mas também, da aptidão deste em transmitir água para as plantas e, as de Reichardt (1978), de que a dinâmica da água no solo depende de inúmeros fatores tais como heterogeneidade do perfil, tipo de planta e condições atmosféricas, entre outras, e que seu conhecimento durante o desenvolvimento da cultura é essencial para o estabelecimento $\mathrm{e}$ aprimoramento das práticas de manejo.

A dinâmica da água em solos saturados e não saturados é um dos fatores mais importantes na atividade agropecuária e seu reflexo sobre a produção agrícola e produtividade das culturas é dos mais visíveis. Nos solos com camadas coesas da unidade de paisagem dos tabuleiros costeiros, os processos que envolvem o 
movimento de água no solo ocorrem sob condições não saturadas, no entanto, é provável que em determinada época do ano, parte da camada do solo situada acima da zona adensada, permaneça sob condições de saturação. Situação como esta foi observada por Libardi (1978), em Terra Roxa Estruturada, onde chegou a registrar pressões positivas na camada superficial do solo em virtude da baixa condutividade hidráulica do horizonte B textural. Estas zonas de saturação se constituem em mais uma dificuldade na compreensão dos fenômenos que envolvem o comportamento da água em solos com perfil heterogêneo, caso dos solos de tabuleiro com camadas coesas, por promoverem alterações rápidas e intensas no estado de energia da água e nas relações envolvendo o seu conteúdo total, o potencial mátrico e a condutividade hidráulica.

Para avaliar a disponibilidade de água para as culturas é necessário o conhecimento preciso da sua dinâmica no solo, sem o qual, não será possível desenvolver estratégias que levem à melhoria dos sistema de produção. Em princípio, são as reservas de água prontamente disponíveis e em teores adequados, que permitem às culturas atravessar sem grandes danos ao seu desenvolvimento, os períodos de déficit hídrico. Este fato por si só já seria suficiente para justificar a atenção especial que deve ser dada ao estudo do movimento de água, em grande parte dos solos da unidade de paisagem dos tabuleiros costeiros, onde as explorações agrícolas são conduzidas, via de regra, sob condições de sequeiro. Letey (1985) enfatiza que é muito dificil definir um valor ótimo para cada um dos fatores fisicos de crescimento e que, esta dificuldade, reside no fato de que os conteúdos de água e ar, como também, a resistência mecânica e a temperatura do solo, além de variarem muito em função do tempo e ao longo do perfil, estão totalmente interrelacionados tornando, praticamente, impossivel alterar o valor de um fator fisico de crescimento sem modificar um ou mais dos outros fatores. Este fato amplia o grau de dificuldade na avaliação da disponibilidade de água para as culturas, em muitas unidades geoambientais dos tabuleiros, devido aos longos períodos de déficit pluvial e à heterogeneidade dos perfis, relacionada, principalmente, à existência de camadas coesas em muitas classes de solo. 


\subsection{1 Água disponível}

Os limites de água disponível baseados na "capacidade de campo" e no "ponto de murcha permanente" correspondem, em geral, aos pontos da curva de retenção de água no solo e são definidos como o conteúdo de água de uma amostra submetida às tensões de 0,01 ou 0,033 MPa e 1,5 MPa, respectivamente. A diferença entre o limite superior e inferior, em uma determinada camada de solo, define o que se chama "água disponivel para as plantas". Este conceito foi durante anos motivo de controvérsias sem que fosse possivel definir uma estrutura teórica compreensível que levasse em consideração todo o conjunto de fatores que afetam o regime hídrico do sistema solo, planta e atmosfera. No entanto, graças à compreensão do estado de energia e do movimento da água no solo, na planta e na atmosfera, além do desenvolvimento de métodos experimentais mais eficientes, foi possível desenvolver uma abordagem consolidada do problema concluindo-se pela inadequação do uso de conceitos estáticos, como capacidade de campo e ponto de murcha permanente, em um sistema dinâmico, embora o movimento de água, apesar de contínuo, apresente fluxos variáveis e em diferentes sentidos (Hillel, 1970).

Diversas críticas a esse método foram feitas por Ritchie \& Amato (1990), entre as quais, estão o fato de que a tensão de 1,5 MPa nem sempre representa o potencial mais baixo que permite às plantas retirar água do solo, que a água acima do limite superior pode também ser utilizada pela planta enquanto a drenagem está ocorrendo, que algumas características do solo que afetam o balanço de água, a exemplo de camadas adensadas, não são consideradas separadamente, que a heterogeneidade de textura, estrutura e porosidade do perfil podem não ser detectadas nas análises de laboratório e que outros processos que ocorrem no campo e não são considerados na determinação da água disponível às plantas, como a evaporação da camada superficial, podem promover, em alguns tipos de solo, perdas consideráveis de água Callot et al. (1982) enfatizam que, por ser um sistema dinâmico, o regime hídrico do solo deve ser avaliado com base na interação de todos os fatores que interferem no 
movimento de água, o qual é regido tanto pela quantidade de água que infiltra no solo, como pela sua dinâmica nos horizontes, intensidade da ascenção capilar, capacidade de absorção de água pelas raízes e condições atmosféricas que interferem na evaporação e taxa de transpiração de água pelas plantas.

A necessidade da análise das interrelações entre os fatores fisicos de crescimento e as propriedades do solo para definição do teor adequado de água às plantas, é um fato incontestável para a grande maioria dos pesquisadores que se dedicam ao estudo da água no solo. Letey (1985) ressalta que o intervalo de água não limitante ao crescimento das plantas pode ser reduzido pela baixa aeração e/ou alta resistência mecânica apresentada por alguns solos como consequência de densidades muito elevadas e/ou devido a problemas na estrutura e que, pequeno intervalo de água disponível às plantas requer manejo especial para manter condições favoráveis ao seu desenvolvimento. Em situações como essa o intervalo de água considerado não limitante para as plantas é, em geral, muito menor do que o previsto pelo método clássico de água disponível. Trabalho conduzido por Silva et al. (1994) em que foram avaliadas as interrelações entre as propriedades do solo, no caso a densidade, com os fatores físicos de crescimento e, tendo como um dos objetivos medir a sensibilidade do índice LLWR (intervalo mínimo de água no solo limitante ao crescimento das plantas) associado com potencial mátrico, aeração e resistência mecânica, demonstrou que a variação natural na densidade de dois tipos de solo promoveu uma grande variação nesse índice.

Apesar de concordar com a ausência de respaldo teórico do método clássico de determinação da capacidade de campo e de enfatizar grande parte das limitações já referidas e inerentes ao próprio método, Reichardt (1988) chama atenção para o fato de que, devido à facilidade encontrada na determinação em laboratório, este tem sido um critério bastante utilizado sendo que, algumas vezes, com resultados consistentes, principalmente, em projetos de irrigação. O autor alerta, no entanto, que, em caso de uso, deve-se optar por potenciais maiores, entre - $-0,01$ e - $-0,006 \mathrm{MPa}$, os quais 
ocorrem com maior frequência em solos submetidos a drenagem, em condições de campo ao invés, dos normalmente utilizados que situam-se entre -0,033 e -0,01 $\mathrm{MPa}$.

A grande maioria dessas observações têm sido testadas e confirmadas ao longo das últimas décadas e contribuído para consolidar a tese de que a água disponivel no solo para as plantas está relacionada aos seus diferentes estados de energia e deve ser vista, portanto, dentro de um conceito biofísico, onde deverão estar envolvidos a planta com todo o seu sistema radicular e outras propriedades que lhe são inerentes, as condições meteorológicas que determinam o regime de transpiração das plantas e de evaporação do solo além de todas as características fisicas do solo que interferem nos fatores físicos de crescimento como potencial e conteúdo de água no solo, aeração, resistência à penetração das raízes e temperatura do solo. Com base nesse pressuposto, é de se esperar, portanto, que quanto maior o número de fatores envolvidos no estudo da dinâmica da água no solo, maior será a aproximação com as condições de campo. Entre os vários métodos existentes para avaliar a dinâmica da água no solo e o seu volume disponivel para uma determinada cultura, em determinado ecossistema e período de tempo, um dos mais utilizados é o balanço da água no campo.

\subsubsection{Balanço hídrico}

O conhecimento de como as plantas utilizam a água do solo e de como respondem aos níveis de armazenagem a partir do balanço hídrico, pode ser uma saída viável para o estabelecimento de estratégias eficazes de manejo visando o melhor uso possível das reservas de água do solo pelas culturas. O movimento cíclico da água na lavoura começa com a sua penetração no solo por meio da infiltração, continua com seu armazenamento temporário na zona do sistema radicular e termina com sua remoção do solo por meio da drenagem, da evaporação e da absorção pelas raízes (Hillel, 1970). O que é feito através do balanço hídrico nada mais é do que tentar quantificar essas entradas e saídas de água no sistema solo-planta. 
Para efetuar o balanço hídrico de uma cultura é necessário, portanto, computar as entradas de água no solo via precipitação pluvial ou irrigação, a partir da sua infiltração na superficie, e as saídas, representadas pela drenagem interna, evapotranspiração e deflúvio superficial num dado volume de solo, baseado na configuração do sistema radicular da cultura em estudo, em determinado período de tempo. Se a quantidade de água que entra no tempo considerado for maior que a quantidade que sai durante o mesmo período, o saldo será positivo, caso contrário, será negativo. Tanto o saldo positivo como o negativo serão medidos pela variação de armazenagem de água no perfil do solo no período considerado (Libardi, 1995).

A representação matemática do balanço hídrico pode ser expressa de acordo com Libardi (1995) através da equação $\Delta \mathrm{h}=\mathrm{P}+\mathrm{I} \pm \mathrm{D}-\mathrm{ET} \pm \mathrm{R}$ onde, $\Delta \mathrm{h}$ corresponde à variação da armazenagem de água no perfil do solo durante o período considerado, sendo as entradas de água representadas pela precipitação pluvial (P) e/ou irrigação (I) e as saídas pela drenagem interna (D), pela evapotranspiração (ET) e deflúvio superficial $(\mathrm{R})$. Tanto a drenagem interna como o deflúvio podem se constituir em incrementos de água negativo ou positivo, justificando a presença de ambos os sinais. Todos os termos da equação podem ser medidos exceção feita à evapotranspiração que pode ser medida indiretamente por métodos climatológicos ou por diferença, explicitando-a na equação anterior, a qual passará a ser representada por $\mathrm{ET}=\mathrm{P}+\mathrm{I} \pm \mathrm{D} \pm \mathrm{R}-\Delta \mathrm{h}$. Os termos $\mathrm{P}, \mathrm{I}$ e $\mathrm{R}$ são determinados por medidas diretas através de pluviômetro, controle de irrigação e por métodos específicos de perdas de água por erosão, respectivamente. A avaliação da variação da armazenagem $\Delta$ h é feita monitorando a umidade do solo por um período de tempo representativo, o que pode ser feito por medidas diretas com o uso de sonda de nêutrons, por exemplo, ou indiretas com tensiômetros associados à curva de retenção.

Para determinação do parâmetro $\mathrm{D}$ (drenagem interna) da equação do balanço hídrico é necessário um estudo amplo das propriedade do solo e do fluido que interferem no fluxo de água. $\mathrm{O}$ entendimento do conceito de potencial da água é essencial 
para a compreensão dos processos envolvidos durante o seu movimento no solo. Da mesma forma, deve-se estar atento para o fato de que o movimento de água no solo não deve ser visto apenas como um fenômeno de redistribuição. Nye \& Thinker (1977) enfatizam que, entre os inúmeros processos que ocorrem durante o movimento de água no solo e na planta, um dos mais importantes está relacionado à participação deste componente no transporte de íons até as raizes, fenômeno este, também regido pela difusividade do líquido e da condutividade hidráulica do solo

\subsubsection{Densidade de fluxo e condutividade hidráulica}

A equação que melhor rege o movimento de água em solos não saturados, equação de Darcy-Buchingham, representada por $q=-K(\theta) \operatorname{grad} \phi_{\mathrm{t}}$, estabelece que a densidade de fluxo q é função da condutividade hidráulica $(K(\theta))$ e do gradiente de potencial total $\left(\operatorname{grad} \phi_{\mathrm{t}}\right)$. A condutividade hidráulica envolve o conhecimento da permeabilidade intrínseca, relacionada ao volume total e distribuição do tamanho dos poros, além da tortuosidade, e das características do fluido como densidade e viscosidade. O gradiente de potencial total, por sua vez, é avaliado através de dois componentes do potencial de água sendo um deles independente da matriz do solo, o componente gravitacional e outro que envolve as interações entre a água e a matriz do solo, o componente mátrico.

A aplicação da teoria do fluxo de água em solo não saturado tanto no campo como em laboratório requer, portanto, o conhecimento da condutividade hidráulica e das características de retenção de água dos solos envolvidos. Muitos métodos podem ser empregados seja sob condições de laboratório usando colunas de solo, como no campo, em perfís de solo. Em ambas situações existem três opções para medição do fluxo: a) tanto o conteúdo de água como seu potencial são medidos, b) apenas o conteúdo de água é medido sendo o potencial estimado com base na curva de retenção de água e c) o potencial de água no solo é medido sendo o seu conteúdo estimado com base na curva de retenção (Klute, 1972). 
Segundo definição de Hillel (1970) o movimento da água no solo é resultante do gradiente de potencial total, o qual ocorre no sentido de potencial total decrescente e, cuja intensidade, é afetada pelo meio físico, principalmente, pelas propriedades geométricas do solo em que ocorrerá o movimento. Este efeito do solo sobre o movimento da água, nada mais é do que o termo $K(\theta)$ da equação, definido por Libardi (1995), como um "coeficiente que expressa a facilidade com que um fluido é transportado através do meio poroso e que depende tanto das propriedades do meio como das do fluido". Para determinação da condutividade hidráulica é necessário criar um plano de fluxo nulo o que se consegue cobrindo a superfície do solo para impedir possiveis trocas com a atmosfera. Este método, segundo Luc (1978), é o único que permite obter, in situ, a relação entre a condutividade hidráulica e a umidade volumétrica (curva $\mathrm{K}(\theta)$ ). Como limitação ao seu uso estão as condições de contorno as quais pressupõem o ar sob pressão atmosférica, solo não expansivo, água pura e sistema isotérmico.

Devido à importância que o meio poroso exerce na drenagem interna da água no solo, vários métodos têm sido propostos para obtenção do volume total e da distribuição do tamanho dos poros no solo. Da mesma forma, várias definições têm sido usadas para classificar os diferentes tamanhos dos poros. Segundo Castle \& Krezdorn (1975) os poros podem ser divididos em não capilares (macroporos) que não retêm água contra a força da gravidade e os capilares (microporos) que são capazes de armazenar água a tensões superiores à força da gravidade. Libardi (1995) por outro lado, cita a classificação de Koorevaar (1983) ${ }^{1}$, o qual classifica os poros em a) macroporos, com diâmetro superior a $100 \mu \mathrm{m}$, e cujas funções seriam a de promover a aeração do solo e a condução da água durante sua infiltração b) mesoporos, com diâmetro entre 30 e $100 \mu \mathrm{m}$, nos quais a condução de água se processaria durante a redistribuição e

\footnotetext{
${ }^{1}$ KOOREVAAR, A.N.; MENELIK, G.; KIRKSEN, C. Elements of soil physics. Amsterdam:Elsevier, 1983. 228p. (Development of Soil Science, 13)
} 
c) microporos, com diâmetro inferior a $30 \mu \mathrm{m}$, que atuariam na armazenagem e nos quais a água apresentaria movimento muito lento.

O caminho da água no sistema solo-planta-atmosfera segue um declínio de potencial que vai do solo para a planta seguindo pelo sistema vascular até os estômatos e destes para a atmosfera onde a água se encontra no menor estado de energia, envolvendo, desta forma, todos os fatores que compõem o meio ambiente: solo, planta, atmosfera. Em algumas unidades geoambientais da unidade de paisagem dos tabuleiros costeiros, a compreensão dos fenômenos que interferem na produtividade das culturas se torna, com frequência, um grande desafio, na medida em que, se compreendidos isoladamente pouca contribuição darão à solução dos problemas, ao mesmo tempo em que, para compreensão dos seus efeitos interrelacionados é necessário envolver um grande número de fatores e a grande diversidade inerente a este ecossistema. Tal situação gera, na maioria das vezes, grande nível de complexidade na interpretação dos resultados experimentais. 


\section{MATERIAL E MÉTODOS}

\subsection{Caracterização da área experimental}

O experimento foi conduzido no Campo Experimental de Umbaúba (CEU), SE, EMBRAPA-Tabuleiros Costeiros, cujas coordenadas geográficas são $11^{\circ} 22^{\prime} 37^{\prime \prime}$ de latitude sul, $37^{\circ} 40^{\prime} 26^{\prime \prime}$ de longitude oeste e altitude média de $109 \mathrm{~m}$. A estação experimental situa-se na região Tabuleiro Sul do Estado de Sergipe da qual fazem parte também os municípios de Salgado, Boquim, Pedrinhas, Arauá, Santa Luzia do Itanhy, Indiaroba e Cristinápolis os quais, junto com Umbaúba, representam o principal polo de produção de citros do Estado. Na Tabela 1 são apresentados os dados meteorológicos em uma série de onze anos onde é possível observar que os valores médios para temperatura, umidade relativa do ar e precipitação pluvial neste período foram de, respectivamente, $24^{\circ} \mathrm{C}, 81 \%$ e $1318 \mathrm{~mm}$, respectivamente Os registros pluviométricos (média anual) obtidos no local da experimentação entre 1994 e 1996 foram de 1312, 1039 e $1295 \mathrm{~mm}$.

A unidade de paisagem dos tabuleiros costeiros acompanha todo o litoral do nordeste do Brasil em área estimada de 8,42 milhões de hectares apresentando, como característica comum a todas as dezessete unidades geoambientais que a compõem, topografia plana a suave ondulada, raramente excedendo $3 \%$, baixa fertilidade natural e elevada profundidade dos solos (EMBRAPA/CPATC, 1996). As diferenças entre as unidades geoambientais estão, em geral, relacionadas às variações na altitude, precipitação pluvial, drenagem e, principalmente, no grau de entalhamento do solo. $\mathrm{O}$ ecossistema de tabuleiro, relacionado ao estudo, faz parte da unidade geoambiental identificada como "L7" no zoneamento agroecológico do Nordeste (Silva et al., 1993) a 
qual inclui a região que vai do extremo sul da Bahia até o norte do Estado de Sergipe onde predominam tabuleiros dissecados com topos planos ou arredondados.

Tabela 1 - Dados climáticos, série de onze anos, entre 1974 e 1987.

\begin{tabular}{|c|c|c|c|c|c|}
\hline \multirow[t]{2}{*}{ Anos } & \multicolumn{3}{|c|}{ Temperatura do ar $\left({ }^{\circ} \mathrm{C}\right)$} & \multirow{2}{*}{$\begin{array}{c}\text { Umidade } \\
\text { relativa } \\
(\%)\end{array}$} & \multirow{2}{*}{$\begin{array}{l}\text { Precipitação } \\
\text { pluvial } \\
(\mathrm{mm})\end{array}$} \\
\hline & Média das máximas & Média das mínimas & Média das normais & & \\
\hline 1974 & 29,0 & 21,5 & 23,9 & 83,4 & 1519,8 \\
\hline 1975 & 29,0 & 19,8 & 23,7 & 82,2 & 1759,6 \\
\hline 1976 & 28,8 & 19,0 & 23,5 & 81,0 & 1115,3 \\
\hline 1977 & 28,5 & 19,6 & 23,5 & 83,4 & 1562,5 \\
\hline 1979 & 29,5 & 20,9 & 24,1 & 81,9 & 1288,4 \\
\hline 1981 & 28,7 & 20,4 & 23,8 & 81,1 & 1043,9 \\
\hline 1982 & 29,1 & 20,8 & 24,3 & 80,9 & 1283,4 \\
\hline 1983 & 29,9 & 21,0 & 24,7 & 79,3 & 989,6 \\
\hline 1984 & 29,1 & 20,9 & 24,6 & 80,4 & 1298,4 \\
\hline 1986 & 28,7 & 20,1 & 23,9 & 82,2 & 1636,8 \\
\hline 1987 & 30,1 & 20,3 & 24,7 & 79,7 & 999,7 \\
\hline Média & 29,1 & 20,4 & 24,1 & 81,4 & 1317,9 \\
\hline
\end{tabular}

Fonte: Estação Experimental de Boquim, Empresa de Desenvolvimento Agropecuário - EMDAGRO, estado de Sergipe.

\subsection{Caracterização das plantas}

Todas as avaliações foram conduzidas em um experimento para avaliação do comportamento de cinco porta-enxertos de citros ao ecossistema de tabuleiro costeiro. A copa utilizada foi Laranja Pêra (Citrus sinensis (L.) Osbeck) em combinação com os porta-enxertos: Limão Volcameriano Palermo e Catânia (Citrus volkameriana Pasquale), Limão Cravo (Citrus limonia Osbeck), Limão Rugoso da Flórida (Citrus jambhiri Lush) e Tangerina Cleópatra (Citrus reshni Hort. ex Tan ), segundo classificação de T. Tanaka (Castle et al. 1989). A quadra de observação foi implantada em julho de 1984 no delineamento experimental de blocos ao acaso com cinco repetições, quatro plantas por parcela e espaçamento entre plantas de $7 \mathrm{~m} \mathrm{x} \mathrm{3,5} \mathrm{m.} \mathrm{As}$ avaliações foram feitas no $11^{\circ}$ ano a partir da implantação do experimento. 


\subsection{Caracterização do solo}

\subsubsection{Classificação do solo, descrição da área e análise morfológica do perfil}

Para identificação da classe de solo da área experimental foi aberta trincheira para classificação do solo e descrição morfológica do perfil além da coleta de amostras, por horizonte, para caracterização química. Estas informações serão apresentadas a seguir à exceção das análises químicas cuja tabela de resultados será apresentada no item resultados e discussão.

\section{Classificação do solo e descrição da área do experimento:}

CLASSIFICAÇÃO: Podzólico Acinzentado eutrófico com fragipan Tb A fraco textura média/argilosa fase floresta subperenifólia relevo plano.

CLASSIFICAÇÃO AMERICANA: Aquic Kandiustalfs.

CLASSIFICAÇÃO DA FAO: Haplic Lixisols.

LOCALIZAÇÃO: Quadra de observação de porta-enxertos.

COBERTURA VEGETAL E USO ATUAL: Pomar de laranjeira Pêra.

COORDENADAS GEOGRÁFICAS E ALTITUDE: $11^{\circ} 22^{\prime} 37^{\prime \prime}$ de latitude Sul e $37^{\circ} 40^{\prime} 26^{\prime \prime}$ de longitude Oeste, $109 \mathrm{~m}$ acima do nível do mar.

LITOLOGIA E FORMAÇÃO GEOLÓGICA: Sedimentos do Grupo Barreiras do Terciário.

MATERIAL ORIGINÁRIO: Sedimentos arenoargilosos e argilosos.

PEDREGOSIDADE, ROCHOSIDADE E EROSÃO: Ausente.

RELEVO LOCAL: Topo plano de tabuleiro (0 a $2 \%$ de declive).

DRENAGEM: Moderadamente drenado.

VEGETAÇÃO PRIMÁRIA: Floresta subperenifólia.

PERFIL descrito pelo pesquisador José Coelho Araújo Filho da EMBRAPA-Centro de solos em 27/09/1995. 


\section{Descrição morfológica do perfil:}

Ap 0 - 0,2 m; 10YR 4/2; franco arenosa; fraca pequena a média, blocos subangulares; muitos poros pequenos poucos médios; muito friável; ligeiramente plástica e ligeiramente pegajosa; transição plana e gradual.

BA $0,2-0,42 \mathrm{~m} ; 10 \mathrm{YR} 5 / 3$; franco argilo-arenosa; fraca pequena a média, blocos subangulares e partes maciças; muitos poros pequenos e poucos médios; friável; plástica e ligeiramente pegajosa; transição plana e gradual.

Bt 0,42 - 0,85 m; 10YR 6/3; mosqueados poucos médios e difusos 7,5YR 5/6; argilo-arenosa; fraca pequena a média blocos subangulares e partes maciças; comuns pequenos e poucos médios; friável; plástica e pegajosa; transição plana e gradual.

Btx $_{1}$ 0,85 - 1,4 m; 10YR 6/3; mosqueados abundantes grandes distintos 10YR 6/6, 2,5YR 4/4 poucos médios e proeminentes; argilo-arenosa; fraca pequena a média blocos subangulares e partes maciças; comuns pequenos e raros médios; friável com partes firmes; plástica e pegajosa; transição plana e gradual.

Btx $_{2}$ 1,4 - 2,0 m ${ }^{(+)}$; coloração variegada 10YR 6/3, 10YR 6/8, 7,5YR 4/4 e 2,5YR 4/6; argilo-arenosa; maciça partes com estrutura fraca pequena blocos subangulares; comuns pequenos; firme muito firme com partes friáveis; plástica e ligeiramente pegajosa.

RAÍZES: Comuns e finas no Ap, poucas e finas no BA e raras e finas nos horizontes $\mathrm{Bt}, \mathrm{Btx}_{1}$ e Btx 2

OBSERVAÇÕES: Solo úmido por ocasião da descrição. No horizonte Bt ocorrem mosqueados sem, no entanto indicar a presença de fragipan (possivelmente ocorram fragipans incipientes). Verificou-se penetração de material escuro ao longo do perfil e de raízes na entrelinha. Não foi observada presença de cerosidade. 


\subsubsection{Caracterização física}

Para coleta das amostras de solo foi aberta uma trincheira, ao lado do experimento e coletada 10 amostras com estrutura indeformada, por horizonte, visando a elaboração da curva de retenção de água e a determinação da densidade do solo. As

amostras deformadas foram coletadas, também por horizonte, para a obtenção da densidade de partículas e da distribuição do tamanho das partículas do solo.

A determinação da distribuição do tamanho das partículas (granulometria) e da densidade das partículas foi feita pelos métodos do densímetro e do picnômetro, repectivamente, com base na metodologia descrita no manual de métodos de análise fisicas da EMBRAPA (Empresa Brasileira de Pesquisa Agropecuária, 1979).

Para determinação das curvas de retenção de água foram coletadas dez amostras com estrutura indeformada por horizonte. A amostragem foi feita utilizando o aparelho de Uhland contendo anéis volumétricos com diâmetro e altura média de $53,7 \mathrm{~mm}$ e $59,9 \mathrm{~mm}$, respectivamente sendo que, cada anel, era composto de três segmentos iguais e separáveis tendo sido utilizado o segmento central para aplicação das tensões. Este cuidado visou a utilização de amostras com pertubação mínima da sua estrutura. Cada uma das dez amostras coletadas foi utilizada para obtenção de cada um dos pontos da curva a qual foi composta pelas tensões de $0,5,1,4,7,10,30,80,100$, 500 e $1500 \mathrm{kPa}$. Os equipamentos utilizados na determinação foram o funil de placa porosa com o qual foram obtidas as tensões $0,5,1,4,7$ e $10 \mathrm{kPa}$ e as câmaras de pressão de Richards com as quais foram obtidas as tensões 30,80,100, 300 e $1500 \mathrm{kPa}$. Ao final da aplicação das tensões cujo momento era definido quando constatava-se completo cessamento da drenagem, tanto nos funis como nas câmaras de pressão, as amostras eram secas em estufa a $105^{\circ} \mathrm{C}$, por 48 horas, para determinação da massa de sólidos. Com esta informação realizava-se também o cálculo da densidade do solo a partir da relação massa do solo seco/volume do anel volumétrico. 
A partir dos valores de umidade associados às tensões aplicadas em laboratório foram obtidos os parâmetros empíricos da equação proposta por Van Genuchten (1980):

$$
\theta=\theta_{r}+\frac{\theta_{s}-\theta_{r}}{\left[1+\left(\alpha\left|\phi_{m}\right|\right)^{n}\right]^{m}}
$$

onde $\theta$ é a umidade volumétrica $\left(\mathrm{m}^{3} \mathrm{~m}^{-3}\right), \theta_{\mathrm{r}}$ a umidade residual $\left(\mathrm{m}^{3} \mathrm{~m}^{-3}\right), \theta_{\mathrm{s}}$ a umidade de saturação $\left(\mathrm{m}^{3} \mathrm{~m}^{-3}\right), \phi_{\mathrm{m}}$ o potencial mátrico $(\mathrm{kPa})$ e $\alpha, \mathrm{m}$ e $\mathrm{n}$ os parâmetros empíricos da equação. O ajuste das curvas foi feito utilizando programa de computador desenvolvido por Dourado Neto et al (1990).

\subsubsection{Caracterização hídrica}

\subsubsection{Condutividade hidráulica}

A metodologia utilizada para determinação da condutividade hidráulica não saturada foi a do perfil instantâneo por ser considerada adequada para solos heterogêneos e com lençol freático profundo, caso da classe de solo estudada. A parcela, situada ao lado do experimento, foi delimitada com tábuas de 0,3 m de altura por 5,5 m de comprimento e enterradas de tal forma que fosse possível aplicar uma lâmina de água de, pelo menos, 0,1 m de altura, homogeneamente em toda a área. Após o preparo da parcela foi instalado um conjunto de oito tensiômetros com manômetro de mercúrio nas profundidade $0,1,0,3,0,5,0,7,0,9,1,1,1,3$ e 1,5 m para medida do potencial mátrico (Figura 1a) e posterior obtenção da umidade volumétrica a partir da curva de retenção de água. O próximo passo constou da saturação do solo por uma fonte permanente de água até que fosse estabelecido fluxo constante até a profundidade de 1,5 m. Esta condição foi considerada satisfeita quando as leituras dos tensiômetros não mais variaram indicando que tinha sido atingida a condição de regime estacionário. Neste estágio, o fornecimento de água foi interrompido e a área coberta com plástico preto para atendimento das condições de contorno do método as quais prevêem completa ausência 
de evaporação e de entrada de água através da superficie (Figura 1b). Com estes cuidados a redistribuição da água pelo processo de drenagem interna foi monitorada durante trinta dias através de medidas diárias do potencial mátrico.

a)

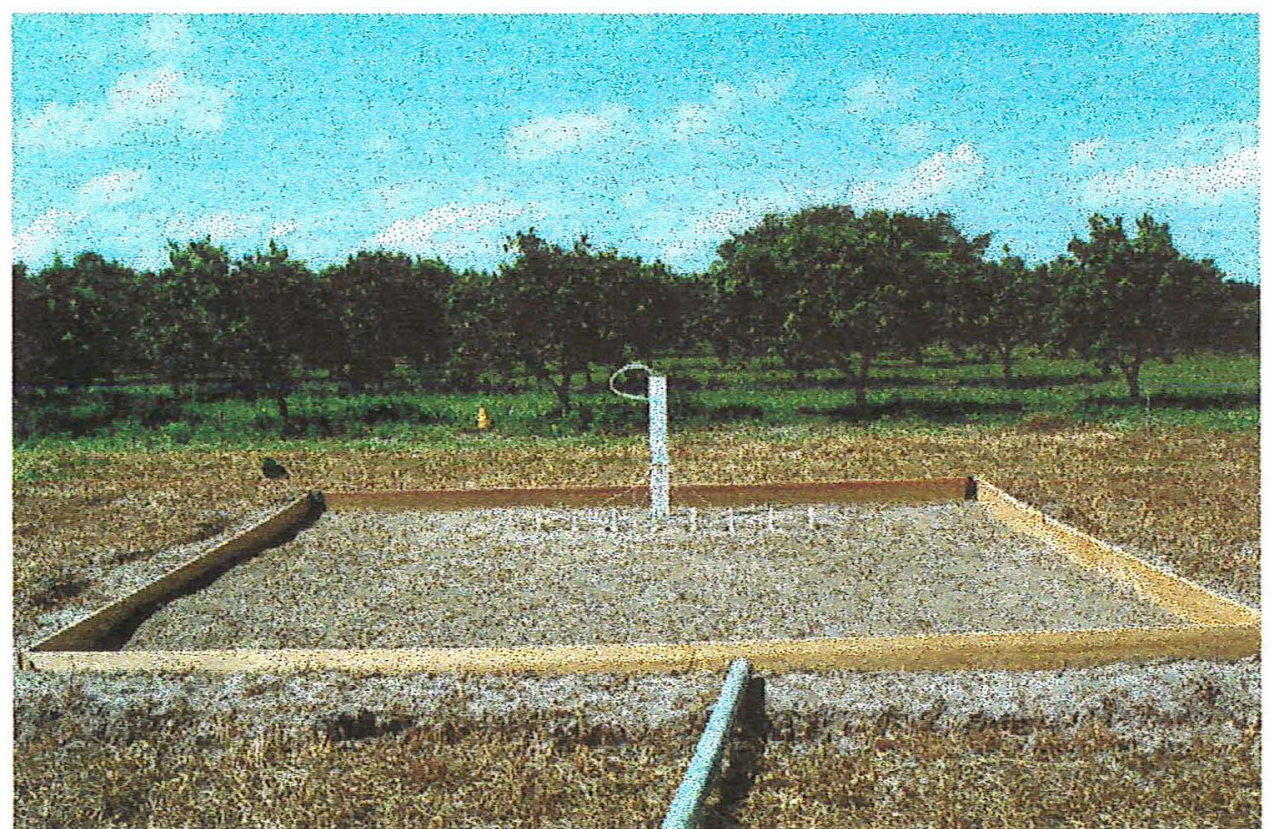

b)

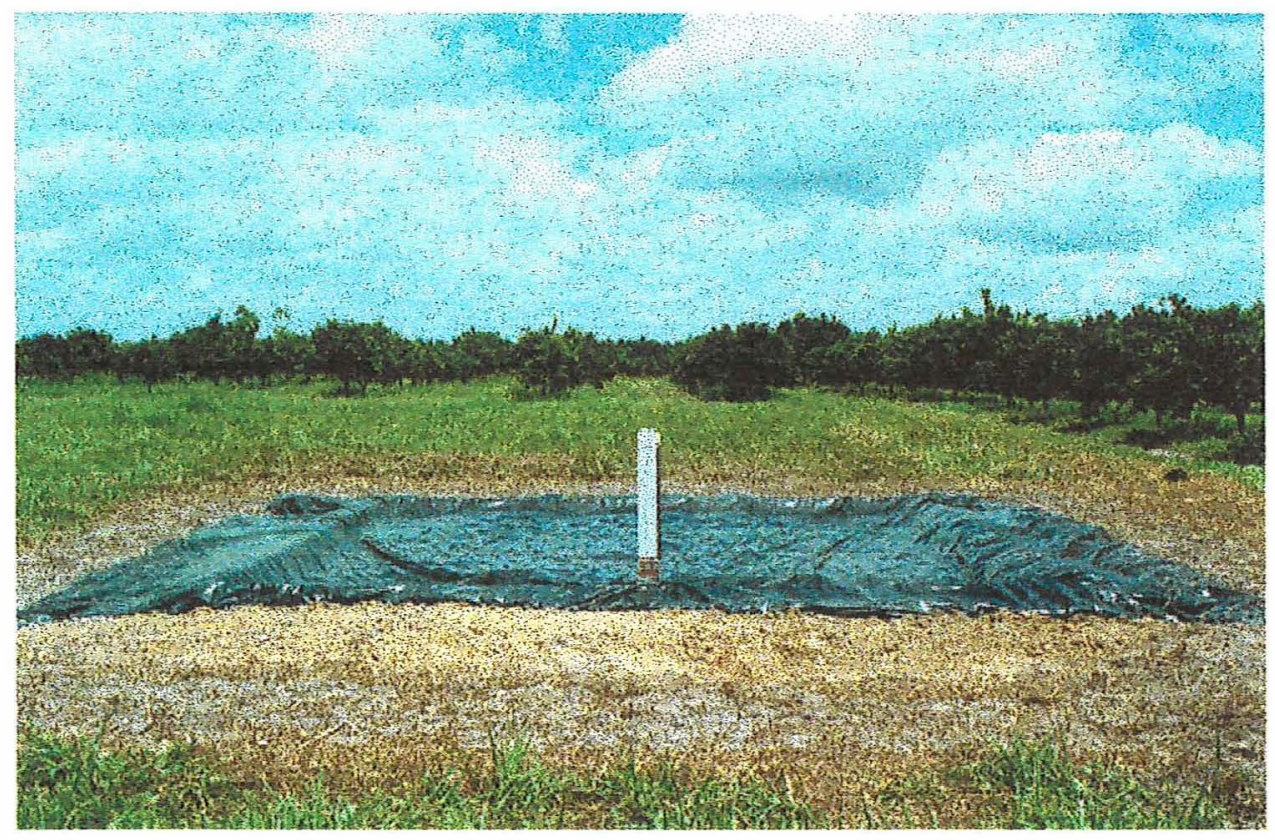

Figura 1 - Detalhe da parcela e do conjunto de tensiômetros (a) e da área coberta com plástico (b), para determinação da condutividade hidráulica. 


\subsubsection{Determinação dos perfís de potencial mátrico em função do tempo}

Para cada porta-enxerto foi instalado um conjunto de oito tensiômetros com manômetro de mercúrio a aproximadamente $2,5 \mathrm{~m}$ do tronco da laranjeira (área da projeção da copa) tendo-se o cuidado de escolher uma planta representativa do total das plantas do experimento. Os tensiômetros, instalados nas profundidade $0,1,0,3,0,5,0,7$, $0,9,1,1,1,3$ el,5 m foram construídos com plástico PVC rígido com diâmetro externo e interno de 0,021 e $0,015 \mathrm{~m}$, respectivamente, e comprimento ajustado às profundidades avaliadas (Figura 2a).

2a)

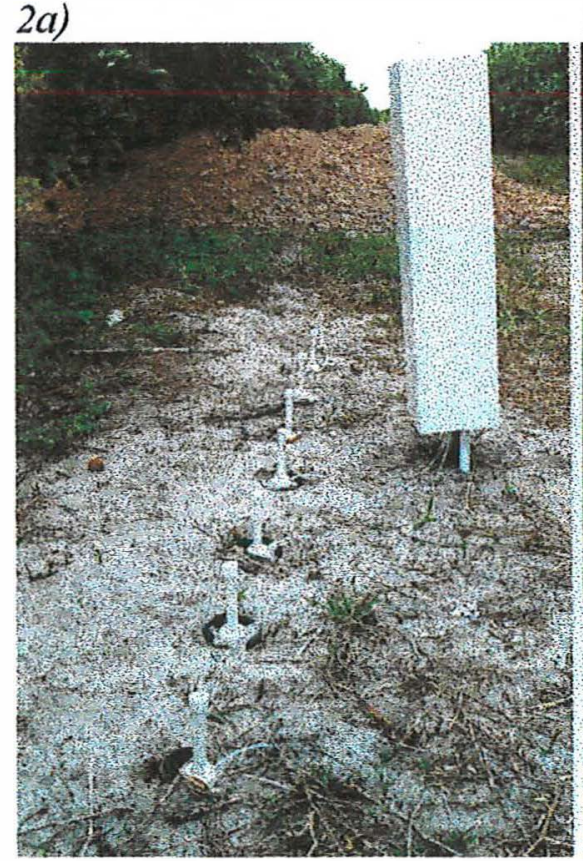

2b)

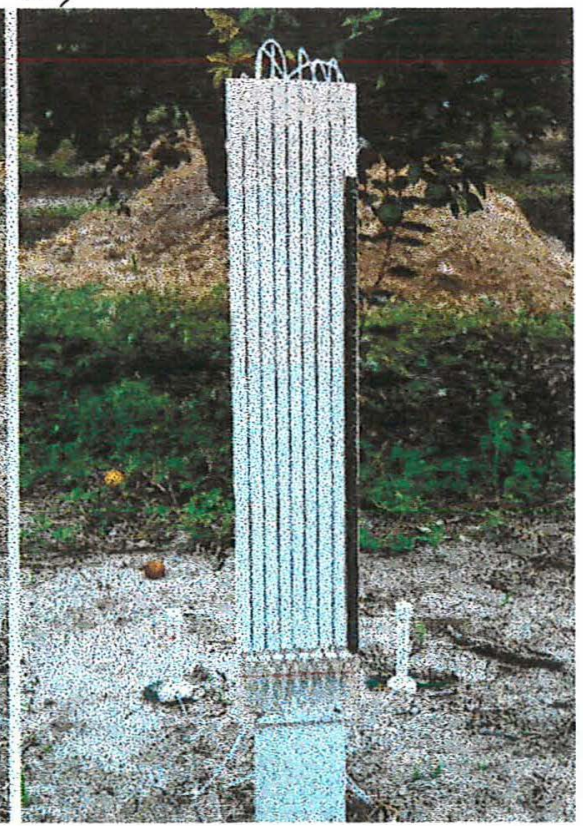

Figura 2 - Detalhe do conjunto de tensiômetros (2a) e do sistema utilizado para a leitura da coluna de mercuirio (2b).

O conjunto de tensiômetros foi ligado, através de tubos de nylon com 0,002 m de diâmetro e comprimento variável, a uma única cuba de acrílico, segmentada em oito partes e presa a uma tábua de madeira onde as leituras da altura da coluna de mercúrio foram efetuadas (Figura 2b). 
O cálculo do potencial mátrico $\left(\phi_{\mathrm{m}}\right)$ foi feito com base na equação apresentada a seguir:

$$
\theta_{\mathrm{m}}=-12,6 \mathrm{~h}+\mathrm{hc}+\mathrm{z}
$$

onde $\mathrm{h}$ corresponde aos valores medidos da coluna de mercúrio, cuja leituras foram realizadas diàriamente e sempre no período da manhã, hc a distância entre a superficie do solo e o nível superior da coluna de mercúrio na cuba e $\mathrm{z}$ a profundidade de instalação da cápsula porosa.

\subsubsection{Componentes do balanço hídrico}

O balanço hídrico no solo onde se encontravam os porta-enxertos foi estimado com base no princípio da conservação das massas o qual pode ser representado pela relação matemática das entradas e saídas de água em determinado volume de solo e pode ser descrito pela equação:

$$
\Delta \mathrm{h}=\mathrm{P} \pm \mathrm{D}-\mathrm{ET}
$$

onde $\Delta \mathrm{h}$ corresponde à variação de armazenagem de água no perfil do solo durante o período considerado, $\mathrm{P}$ à precipitação pluvial, $\mathrm{D}$ à drenagem interna ou ascenção capilar e ET à evapotranspiração. Como o parâmetro D pode se constituir em entrada ou saída de água a sua representação matemática é feita com ambos os sinais, positivo e negativo. Todos os componentes da equação foram medidos à exceção da evapotranspiração o qual foi calculado explicitando-o da equação 3 como representado a seguir:

$$
\mathrm{ET}=\Delta \mathrm{h}-\mathrm{P} \pm \mathrm{D}
$$

Os parâmetros I (irrigação) e R (deflúvio superficial) que normalmente fazem parte da equação do balanço hídrico não foram considerados neste trabalho em 
virtude da experimentação ter sido realizada sob condições de sequeiro e em solo com declive praticamente plano onde o deflúvio foi considerado nulo.

O balanço foi realizado em um volume de solo de área unitária na profundidade $0<z<L$ durante $o$ intervalo de tempo $t_{1}-t_{0}$. A profundidade $z$ considerada foi de $1,1 \mathrm{~m}$ e os intervalos de tempo, segmentados do periodo total de um ano de acompanhamento, para todos os cinco porta-enxertos, foram: 01/12/95 a 25/03/96 (1), 26/03 a 15/04 (2), 16/04 a 15/05 (3), 16/05 a 10/06 (4), 11/06 a 30/06 (5), 01/07 a 31/07 (6), 01/08 a 31/08 (7), 01/09 a 30/09 (8), 01/10 a 31/10 (9) e 01/11 a 30/11 (10). Os intervalos de tempo 1,2,9 e 10 corresponderam à estação seca e os intervalos 3,4,5,6,7 e 8 à estação chuvosa.

A precipitação pluvial foi medida com pluviômetro e o fluxo de água (q), que drena (drenagem interna, -D) ou ascende (ascenção capilar, $+D$ ) ao volume de solo considerado, foi medido com base na equação da Darcy-Buckingham:

$$
\mathrm{q}=-\mathrm{K}(\theta) \operatorname{Grad} \phi_{\mathrm{t}}
$$

onde $\mathrm{K}(\theta)$ é a condutividade hidráulica do solo não saturado ( $\mathrm{m} \mathrm{dia}^{-1}$ ) função da umidade do solo $(\theta)$ e que expressa a facilidade com que a água é transportada e Grad $\phi_{t}$ é o gradiente do potencial total. O gradiente foi obtido pela diferença do potencial total $\left(\phi_{t}\right)$ entre os pontos $0,9 \mathrm{~m}$ e $1,3 \mathrm{~m}$ dividido pela distância $(\Delta z)$ entre eles $(0,4 \mathrm{~m})$ :

$$
\operatorname{Grad} \phi_{\mathrm{t}}=\frac{\phi_{\mathrm{t}(0,9 \mathrm{~m})}-\phi_{\mathrm{t}(1,3 \mathrm{~m})}}{\Delta \mathrm{z}_{(0,4 \mathrm{~m})}}
$$

A variação de armazenagem $\Delta \mathrm{h}$ foi determinada pela diferença dos valores de umidade obtidos no perfil ( $\bar{\theta}$ de 0 a $\mathrm{L}$, sendo $\mathrm{L}$ igual a $1,1 \mathrm{~m}$ ) nos tempos final e inicial de cada período considerado podendo ser expressa pela equação: 


$$
\Delta h=\bar{\theta}_{(f)}-\bar{\theta}_{(\mathrm{i})} \cdot \mathrm{L}
$$

\subsubsection{Eficiência do uso da água (EUA)}

O índice eficiência do uso da água, calculado com base em Hillel (1972), foi obtido através da relação entre o rendimento da laranja Pêra nas diferentes combinações com os porta-enxertos avaliados, e a taxa de evapotranspiração anual, podendo ser expresso pela equação:

$$
E U A=\frac{y_{w}}{E T_{a}}
$$

onde $y_{w}$ corresponde ao rendimento obtido em $\mathrm{kg} \mathrm{ha}^{-1} \mathrm{ano}^{-1}$ e $E T_{a}$ a evapotranspiração anual, calculada pelo método do balanço hídrico na camada 0,0 a $1,1 \mathrm{~m}$, em mm de água.

\subsection{Avaliação da distribuição do sistema radicular dos porta enxertos}

A metodologia utilizada nesta avaliação se baseou na técnica de processamento e análise de imagens digitais para determinação do comprimento e área das raízes por quadrícula e no total do perfil analisado, cujos princípios são discutidos em detalhes no documento da EMBRAPA Instrumentação Agropecuária, São Carlos, SP (Cruvinel et al., 1996). As recomendações práticas para aquisição das imagens no campo e para utilização do SIARCS (Sistema Integrado para Análise de Raizes e Cobertura do Solo), programa de computador a partir do qual as imagens foram tratadas, são descritas em circulares técnicas da mesma instituição (Jorge et al., 1996; Jorge \& Crestana, 1996) e em documento que relata as experiências para aquisição e tratamento de imagens descrito por Cintra \& Neves (1996). A seguir serão apresentados os procedimentos utilizados neste trabalho. 


\subsubsection{Aquisição de imagens no campo}

Foram abertas, manualmente, em direção ao centro da entre-linha de plantio, quinze trincheiras sendo três para cada porta-enxerto, com as dimensões de 3,5 $\mathrm{m}$ de comprimento por 1,3 $\mathrm{m}$ de altura e 1,2 $\mathrm{m}$ de largura (Figura 3). Após a abertura foi feito o nivelamento para deixá-la o mais plano possível e distante $0,2 \mathrm{~m}$ do tronco da laranjeira. As etapas seguintes constaram de escarificação da parede da trincheira com rolo de prego para exposição das raízes, pintura com tinta spray branca para obtenção do melhor contraste possível entre as raízes e o solo, pré-umedecimento do perfil com pulverizador costal também visando a obtenção de bom contraste e colocação de grade (dimensões de 3,4 $\mathrm{m}$ de largura e 1,2 $\mathrm{m}$ de altura) subdividida em quadrículas de $0,2 \mathrm{~m} \times 0,2 \mathrm{~m}$ nas quais a filmagem era realizada.

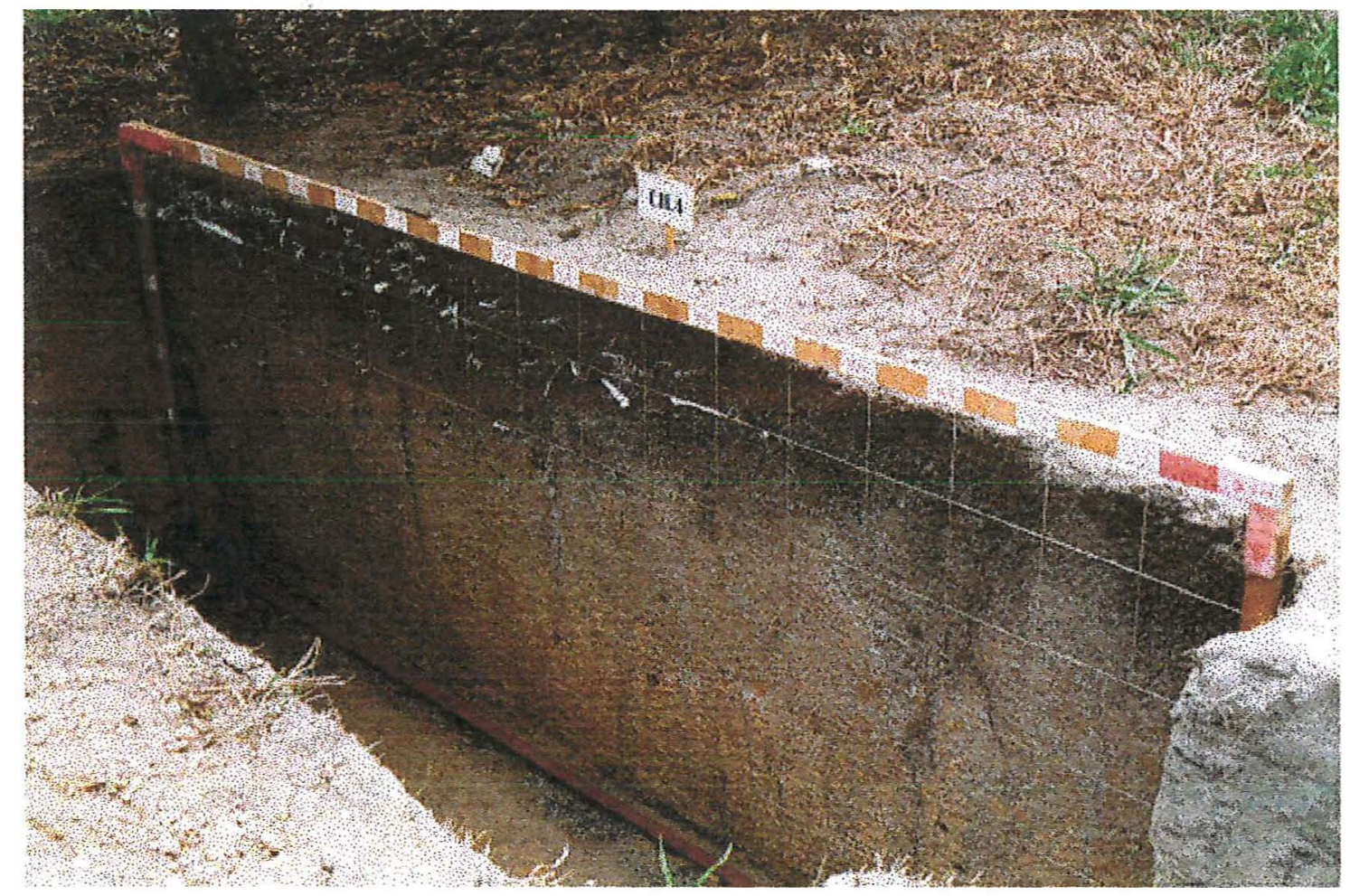

Figura 3 - Detalhe da trincheira utilizada para aquisição das imagens das raízes.

As imagens foram obtidas utilizando câmara de vídeo e as filmagens realizadas com controle total da luz natural o que só foi possível construindo-se uma 
cobertura móvel, revestida com plástico preto, a qual era colocada sobre a trincheira durante a filmagem. Para iluminação do perfil foi utilizada lâmpada halógena de 300 watts cuja intensidade de luz permitiu, junto com outros cuidados, a obtenção de imagens com bom grau de definição. O tempo de filmagem gasto por quadrícula variou entre 3 e 5 segundos.

\subsubsection{Processamento e análise das imagens}

$\mathrm{O}$ tratamento das imagens constou de duas fases, ambas realizadas no Laboratório de Imagens da EMBRAPA Instrumentação Agropecuária, estando a primeira relacionada à aquisição das imagens em computador e a segunda ao tratamento propriamente dito utilizando o SIARCS. As imagens de todas as quadrículas filmadas foram digitalizadas em placa digitalizadora acoplada ao computador e armazenadas em formato padrão. Com a finalização da aquisição cada quadrícula era transferida para o ambiente SIARCS onde era dada continuidade à rotina do programa analisando-se cada imagem por área de $0,2 \mathrm{~m} \times 0,2 \mathrm{~m} \mathrm{e}$, posteriormente, por área de $0,05 \mathrm{~m} \times 0,2 \mathrm{~m}$, até a profundidade de $0,5 \mathrm{~m}$. Esta segmentação da quadrícula até $0,5 \mathrm{~m}$ foi realizada devido à constatação, após uma primeira análise, de que a grande maioria das raízes concentravam-se nas camadas superficiais do solo. Para análise da variável comprimento das raízes o programa permitiu gerar o afinamento das raízes (processo denominado esqueletonização) de tal forma que todas pudessem apresentar o mesmo tamanho de pixel, uniformizando, desta maneira, a medida de comprimento independente da espessura das raízes.

Os resultados obtidos expressos em área $\left(\mathrm{m}^{2}\right)$ e comprimento $(\mathrm{m})$ de raízes por área da quadrícula $\left(0,01 \mathrm{~m}^{2}\right)$ foram submetidos à análise de variância segündo modelo de blocos ao acaso em esquema de parcelas subdivididas com três repetições, sendo os porta-enxertos os tratamentos e as profundidades os sub-tratamentos. Para comparação das médias entre porta-enxertos utilizou-se o teste de Tuckey ao nível de 5\% e, na comparação dos níveis de profundidade foram efetuadas análises de regressão polinomial. 


\section{RESULTADOS E DISCUSSÃO}

\subsection{Tabuleiros costeiros}

\subsubsection{Aspectos climáticos}

Os dados climáticos da região sul do Estado de Sergipe que inclui a área experimental, apresentados na Tabela 1, demonstram a existência de condições bastante favoráveis à maioria das culturas tropicais com temperatura média anual ao redor de $24^{\circ} \mathrm{C}$, média das máximas de $29^{\circ} \mathrm{C}$ e média das mínimas de $19^{\circ} \mathrm{C}$. Segundo Benvington \& Castle (1985) um rítimo mais intenso de crescimento das raízes de citros é, em geral, obtido com temperaturas em torno de $27^{\circ} \mathrm{C}$ e mais limitado abaixo de $22^{\circ} \mathrm{C}$. Com base nesta informação pode-se inferir que sob condições normais de suprimento de água e manejo da cultura, as temperaturas registradas nesse ecossistema não são limitantes ao desenvolvimento dos citros.

Os efeitos positivos das condições climáticas para exploração dos citros nos tabuleiros, principalmente temperatura, são, no entanto, minimizados pela má distribuição da precipitação pluvial que, associada às características do solo, gera prejuizos ao desenvolvimento desta cultura apesar do volume total das chuvas, em torno de $1300 \mathrm{~mm}$ anuais, se assemelhar bastante ao das principais regiões produtoras de citros do mundo. Na Figura 4 observa-se a existência de dois períodos climáticos bem definidos, uma estação chuvosa, entre abril e setembro e uma estação seca, entre outubro e março. Verifica-se nesta Figura e na Tabela 2 a mesma tendência na distribuição das chuvas durante o período da experimentação. 


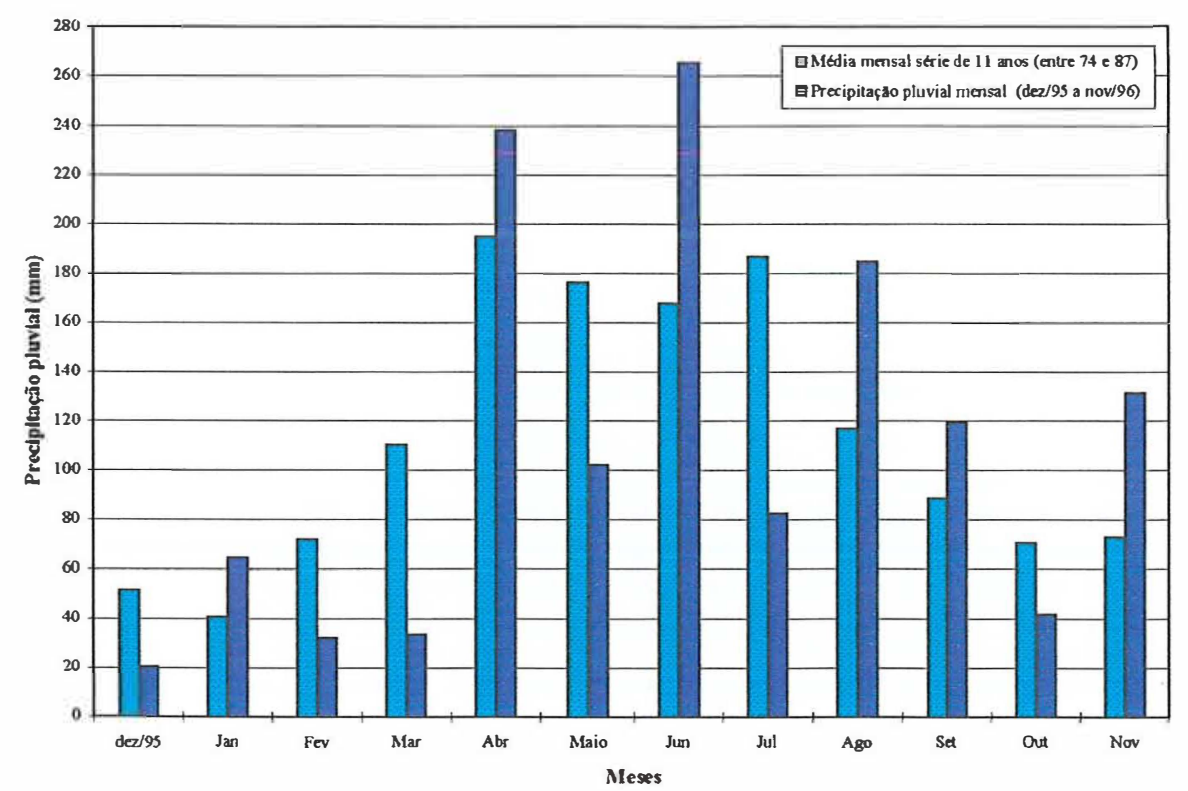

Figura 4- Distribuição média mensal da precipitação pluvial, série de 11 anos e durante o periodo do experimento.

Tabela 2 - Precipitação pluvial entre dezembro de 1995 e novembro de 1996 (mm).

\begin{tabular}{|c|c|c|c|c|c|c|c|c|c|c|c|c|}
\hline \multirow[b]{2}{*}{ Dias } & \multicolumn{12}{|c|}{ Meses } \\
\hline & $\operatorname{dez} / 95$ & jan & fev & mar & $a b r$ & maio & jun & jul & 290 & set & out & nov \\
\hline 1 & & & & 0,8 & 4,8 & & 6,2 & 0,2 & 0,6 & 2,2 & & \\
\hline 2 & & 29 & & 0,6 & 5,2 & & 2,2 & & & & 5,8 & \\
\hline 3 & & 4,8 & & 0,4 & 6,8 & & 17,8 & & 1 & 3,2 & 0,2 & \\
\hline 4 & & & & & 0,8 & 1,8 & 91,6 & & 11,6 & & & \\
\hline 5 & & & & & 13,2 & 0,6 & 9,4 & 6 & 2,8 & 2,3 & & 10,4 \\
\hline 6 & 20 & & & 8 & 0,6 & 0,8 & 1,8 & 0,4 & 3,4 & & & 9,2 \\
\hline 7 & 0,4 & 0,6 & & & 15 & & 10 & 11,8 & & 0,8 & & 17,8 \\
\hline 8 & & & & & 10,6 & & 3,4 & & 12,2 & & 6,6 & 5,4 \\
\hline 9 & & & & & 0,8 & 3,2 & 3,8 & & 82,8 & 2,8 & 1,6 & 0,2 \\
\hline 10 & & & & & 7,2 & & 3,6 & & 0,4 & 5,2 & & 1,4 \\
\hline 11 & & & & & 9,4 & 0,6 & 1,2 & & & 19,8 & & 0,6 \\
\hline 12 & & 2 & 0,6 & & 16,4 & 13,4 & 21,2 & & 1 & 2,8 & & \\
\hline 13 & & 2,8 & 4,2 & & 0,2 & & 34,6 & & 4,2 & 21,8 & & \\
\hline 14 & & & 2,2 & & 6,8 & & 0,4 & 2,4 & & 15 & & \\
\hline 15 & & 1 & 2,8 & & 1,6 & & 17,6 & 0,4 & & 7,4 & & \\
\hline 16 & & 0,1 & & 4,8 & 9,2 & & 12,2 & 1,2 & & & & \\
\hline 17 & & & & & 1,4 & 5,4 & 1 & 0,8 & 10,4 & & & \\
\hline 18 & & & 10 & 6 & 0,2 & 3,2 & 0,6 & 11,6 & 21,8 & 8,4 & 10 & 2,6 \\
\hline 19 & & 3,4 & 1,2 & & 4,2 & 5,2 & 0,2 & 1,8 & 1,4 & 6 & 4,2 & \\
\hline 20 & & 0,6 & & & 32,8 & 1,2 & 8 & & 3,2 & 1,4 & 9,8 & \\
\hline 21 & & 0,6 & & & 7,4 & 2,6 & 8,2 & & & 1 & & \\
\hline 22 & & 0,6 & & & & 15,2 & & 3,8 & 17,8 & 0,8 & & \\
\hline 23 & & 4,6 & 5,4 & & 7,2 & & & 11 & & 0,2 & 2,6 & 38,4 \\
\hline 24 & & & 0,4 & & 1,8 & & 2,6 & 3,6 & & 1,8 & 0,8 & 0,8 \\
\hline 25 & & & 5,4 & & 5,2 & 3,4 & 7 & & 0,4 & & & 4 \\
\hline 26 & & & & & 0,6 & 0,6 & 0,2 & 0,6 & 4,4 & & & 1 \\
\hline 27 & & 10,4 & & & & & & 2,8 & & 11,6 & & 11,8 \\
\hline 28 & & 3,2 & & & 27,2 & 9,2 & & 1,4 & & 4,8 & & 7 \\
\hline 29 & & 0,8 & & 5,2 & 41,8 & 27,2 & 0,8 & 6,4 & 2,8 & & & 6 \\
\hline 30 & & & & 7,2 & & 8,6 & & 13,6 & 1 & & & 14,8 \\
\hline 31 & & & & 0,6 & & & & 26 & 1,4 & & & \\
\hline Total/mês & 20,4 & 64,5 & 32,2 & 33,6 & 238,4 & 102,2 & 265,6 & 82,4 & 184,6 & 119,3 & 41,6 & 131,4 \\
\hline
\end{tabular}


Sob condições de falta de água muitas alterações químicas, principalmente, hormonais ocorrem na planta cítrica, sendo que, a perda das reservas energéticas é a alteração mais importante. Este processo que é iniciado com o fechamento dos estômatos provoca a paralização da fotossíntese e, com o agravamento da desidratação, há aumento acentuado no consumo das reservas da planta e no potencial osmótico das células repercutindo na morte das folhas, ramos e radicelas prejudicando a planta, muitas vezes, de forma irreversível Lima (1995).

\subsubsection{Solos}

Quanto ao solo, cujas principais características físicas são apresentadas na Tabela 3, foi classificado com base na Classificação Brasileira, como Podzólico Acinzentado eutrófico com fragipan e como Aquic Kandiustalfs (Estados Unidos, 1992) e Haplic Lixisols (Driessen \& Dudal, 1991), nas classificações Americana e da FAO, respectivamente. Todas estas classificações prevêem a formação de zonas temporárias de saturação, no primeiro metro a partir da superficie do solo durante a estação chuvosa, e a fertilidade natural caracterizada pela baixa capacidade de troca de cátions. A Classificação Americana resume bem o ecossistema trabalhado indicando, na própria denominação, o regime ústico de umidade (ustic), caracterizado pela existência de um período de seca entre 90 e 180 dias, o caráter kândico (Kandic) do solo associado à baixa capacidade de troca de troca de cátions e a condição de saturação (Aquic) que representa a existência de períodos de encharcamento.

Tabela 3 - Distribuição das partículas do solo $\left(\mathrm{g} \mathrm{kg}^{-1}\right)$, densidade do solo $\left(\mathrm{kg} \mathrm{dm}^{-3}\right)$, e porosidade total $(\%)$.

\begin{tabular}{|c|c|c|c|c|c|c|c|c|c|c|c|}
\hline \multirow[t]{2}{*}{ Horiz. } & \multirow{2}{*}{$\begin{array}{l}\text { Prof. } \\
\text { (m) }\end{array}$} & \multicolumn{5}{|c|}{ Frações de Areia* } & \multirow{2}{*}{$\begin{array}{c}\text { Areia } \\
\text { total }\end{array}$} & \multirow[t]{2}{*}{ Silte } & \multirow[t]{2}{*}{ Argila } & \multirow{2}{*}{$\begin{array}{l}\text { Densidade } \\
\text { do solo }\end{array}$} & \multirow{2}{*}{$\begin{array}{l}\text { Porosidade } \\
\text { total }\end{array}$} \\
\hline & & AMG & $\mathrm{AG}$ & $\mathrm{AM}$ & $\mathrm{AF}$ & AMF & & & & & \\
\hline Ap & $0,00-0,20$ & 37,00 & 200,45 & 303,0 & 196,65 & 61,50 & 798,60 & 60,90 & 140,50 & 1,54 & 40,95 \\
\hline $\mathrm{BA}$ & $0,20-0,42$ & 26,40 & 155,30 & 249,0 & 173,60 & 63,90 & 668.20 & 65,25 & 266,55 & 1,72 & 33,88 \\
\hline $\mathrm{Bt}$ & $0,42-0,85$ & 29,30 & 130,15 & 196,70 & 147,80 & 63,55 & 567,50 & 79,75 & 352,75 & 1,63 & 36,76 \\
\hline Btxl & $0,85-1,40$ & 19,30 & 105,30 & 170,70 & 130,60 & 71,20 & 497,10 & 153,80 & 349,10 & 1,55 & 39,08 \\
\hline $\mathrm{Btx} 2$ & $1,40-2,00^{+}$ & 22,50 & 94,25 & 153,30 & 130,60 & 75,80 & 476,45 & 203,85 & 319,70 & 1,53 & 40,00 \\
\hline
\end{tabular}

* AMG - Areia muito grossa(2 a $1 \mathrm{~mm}$ ), AG - Areia grossa (1 a $0,5 \mathrm{~mm}), \mathrm{AM}$ - Areia média $(0,5$ a $0,25 \mathrm{~mm})$

$\mathrm{AF}$ - Areia fina $(0,25$ a $0,1 \mathrm{~mm}), \mathrm{AMF}$ - Areia muito ina $(0,1$ a $0,05 \mathrm{~mm})$ 
As zonas de saturação são resultantes, provavelmente, da concentração das chuvas em poucos meses do ano associada às camadas de solo coesas, parcialmente impermeáveis. A estas camadas são atribuídas grande parte dos problemas de produtividade das espécies nesse ecossitema, especialmente dos citros, pela sensibilidade que esta cultura apresenta tanto aos baixos suprimentos de água quanto à má aeração do solo. Oliveira (1991) ressalta a vulnerabilidade dos citros às condições de má drenagem devido ao efeito sobre a oxigenação e taxa de difusão dos gases. Alerta que, muitas vezes, a baixa concentração de oxigênio na rizosfera pode promover a parada completa do crescimento das raízes das plantas.

Com relação à baixa fertilidade natural do solo, observa-se na Tabela 4, onde estão relacionados os resultados das análises químicas, que ela é resultante da baixa capacidade de troca de cátions (valor T) em todo o perfil, inclusive no horizonte Ap onde está concentrada a quase totalidade do sistema radicular. Chama à atenção nesta Tabela, a alta saturação por bases (valor V) pouco comum nos solos desse ecossistema a qual, neste caso, é reflexo dos baixos teores de alumínio e hidrogênio. A baixa acidez observada elimina qualquer possibilidade de que uma possível superficialização das raízes, ítem que será discutido no próximo capítulo, tenha relação com a existência de barreira química à penetração do sistema radicular. Sob condições de elevada acidez, situação muito comum em solos de tabuleiro onde é possível encontrar saturação por alumínio em torno de $80 \%$, é provável que haja participação relevante desse fenômeno na distribuição do sistema radicular em profundidade. Segundo Souza (1997) a pobreza em nutrientes e a alta saturação por alumínio traduzem-se, muitas vezes, em impedimento químico ao aprofundamento das raízes em muitas classes de solo dos tabuleiros costeiros. 
Tabela 4 - Resultado das análises de fertilidade e ataque sulfúrico, por horizonte.

\begin{tabular}{|c|c|c|c|c|c|c|c|c|c|c|c|c|c|c|c|c|c|c|c|}
\hline \multicolumn{19}{|c|}{ Horiz $\mathrm{pH}$} & \multirow{3}{*}{$\begin{array}{l}\mathrm{Al}_{2} \mathrm{O}_{3} / \\
\mathrm{Fe}_{2} \mathrm{O}_{3}\end{array}$} \\
\hline & $\mathrm{H}_{2} \mathrm{O}$ & M.O. & $\mathrm{Ca}$ & $\mathrm{Mg}$ & $\mathrm{K}$ & $\mathrm{Na}$ & $\mathrm{s}$ & $\mathrm{Al}$ & $\mathrm{H}$ & $\mathrm{T}$ & \multirow{2}{*}{$\begin{array}{l}\mathrm{V} \\
\%\end{array}$} & $P$ & \multirow{2}{*}{\multicolumn{3}{|c|}{$\frac{\mathrm{SiO}_{2} \mathrm{Al}_{2} \mathrm{O}_{3} \mathrm{Fe}_{2} \mathrm{O}_{3}}{\mathrm{mmol}_{\mathrm{c}} \mathrm{kg}^{-1}}$}} & $\mathrm{TiO}_{2}$ & $\mathrm{Ki}$ & $\mathrm{Kr}$ & \\
\hline & & $\mathrm{g} \mathrm{kg}^{-1}$ & & & & $\mathrm{mmol}$ & $\mathrm{ckg}^{-1}$ & & & & & $\mathrm{mg} \mathrm{dm}^{-3}$ & & & & & & & \\
\hline Ap & 4,8 & 2,2 & 6 & 5 & 0,45 & 1,37 & 12,8 & 3 & 13 & 28,8 & 44 & 5,3 & 66 & 59 & 5 & 4,8 & 1,9 & 1,8 & 18,5 \\
\hline $\mathrm{BA}$ & 4,7 & 1,3 & 7 & 4 & 0,20 & 1,15 & 12,4 & 3 & 11 & 26,4 & 47 & 1,4 & 100 & 100 & 8 & 6,9 & 1,7 & 1,6 & 19,6 \\
\hline $\mathrm{Bt}$ & 4,8 & 1,3 & 10 & 6 & 0,19 & 0,79 & 17,0 & 2 & 7 & 26,0 & 65 & 0,5 & 137 & 129 & 11 & 8,4 & 1,8 & 1,7 & 18,4 \\
\hline Btxl & 4,9 & 0,8 & 12 & 5 & 0,19 & 0,90 & 18,1 & 1 & 9 & 28,1 & 64 & 0,4 & 167 & 157 & 14 & 10 & 1,8 & 1,7 & 17,6 \\
\hline Btx2 & 5,0 & 0,9 & 11 & 6 & 0,25 & 0,97 & 18,2 & 2 & 11 & 31,2 & 58 & 0,4 & 177 & 180 & 25 & 11 & 1,7 & 1,5 & 11,3 \\
\hline
\end{tabular}

Pelos resultados da distribuição do tamanho das partículas do solo apresentados na Figura 5 é possível perceber os primeiros indícios da existência de uma camada coesa, através da redução e aumento, em torno de $13 \%$, dos teores de areia e argila, respectivamente, entre os horizontes Ap e BA. A constatação deste fenômeno, nos primeiros $0,4 \mathrm{~m}$ do solo que inclui o horizonte $\mathrm{Ap}$ e o horizonte de transição $\mathrm{BA}$, permite pressupor a existência de algo a mais do que o simples gradiente textural típico dos solos podzolizados, o que pode estar relacionado de alguma forma, a uma das teorias utilizadas para explicar a gênese dos horizontes coesos. Nesta teoria, atribui-se à migração da argila da camada superficial para a subjacente (neste caso do Ap para o BA) a formação de camadas coesas devido às alterações que esta migração promove na macroporosidade $\mathrm{e}$ densidade do solo (Reunião Técnica sobre Solos Coesos dos Tabuleiros Costeiros, 1996a). Vale lembrar que não foi feito a análise mineralógica da argila depositada nos horizontes subsuperficiais, a partir da qual, seria possível detectar a sua origem, se transportada ou proveniente do material original do solo. 


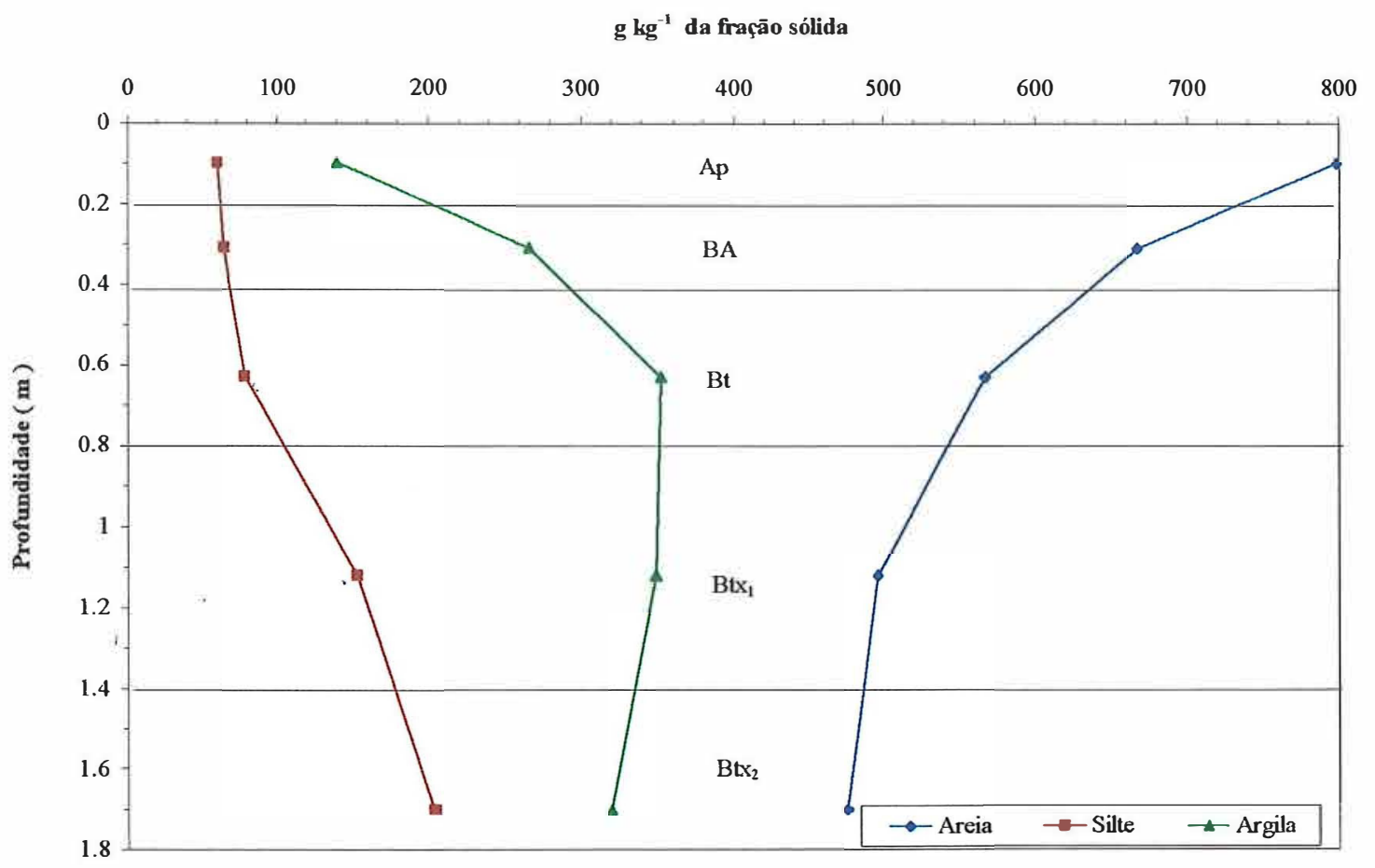

Figura 5 - Distribuição do tamanho das partículas do solo, por profundidade.

Quanto ao fracionamento da areia verifica-se na Figura 6 a predominância das frações intermediárias (areia grossa, média e fina) com diâmetro entre 1,0 e $0,1 \mathrm{~mm}$, em todo o perfil do solo sendo, no entanto, bastante superior à quantidade de areia com diâmetro médio (entre 0,5 e $0,25 \mathrm{~mm}$ ). Nas três frações a redução é acentuada entre os horizontes Ap e Bt, a partir do qual os teores caem mais lentamente. Os percentuais de areia muito grossa $(2$ a $1 \mathrm{~mm})$ e de areia muito fina $(0,1$ a $0,05 \mathrm{~mm})$ são muito baixos e, praticamente, não sofrem alteração ao longo do perfil. É possível, no entanto, que parte da areia muito fina possa estar incluída no percentual de silte, o qual, aumenta bastante a partir do horizonte Bt (Figura 5). Vale lembrar que o limite inferior da areia muito fina $(0,05 \mathrm{~mm})$ coincide com o limite superior do silte. Souza (1997) ressalta que o predomínio das frações mais finas na areia total (frações com diâmetro médio entre 0,5 e $0,25 \mathrm{~mm}$ ) associado à densidade elevada do solo, baixa porosidade total, baixa macroporosidade e alto grau de argila dispersa em água, é um dos fatores que contribuem para aumentar a susceptibilidade dos solos de tabuleiro à erosão e de reduzir 
a sua capacidade em suprir oxigênio às plantas por facilitar a formação das camadas coesas e de zonas periódicas de encharcamento.

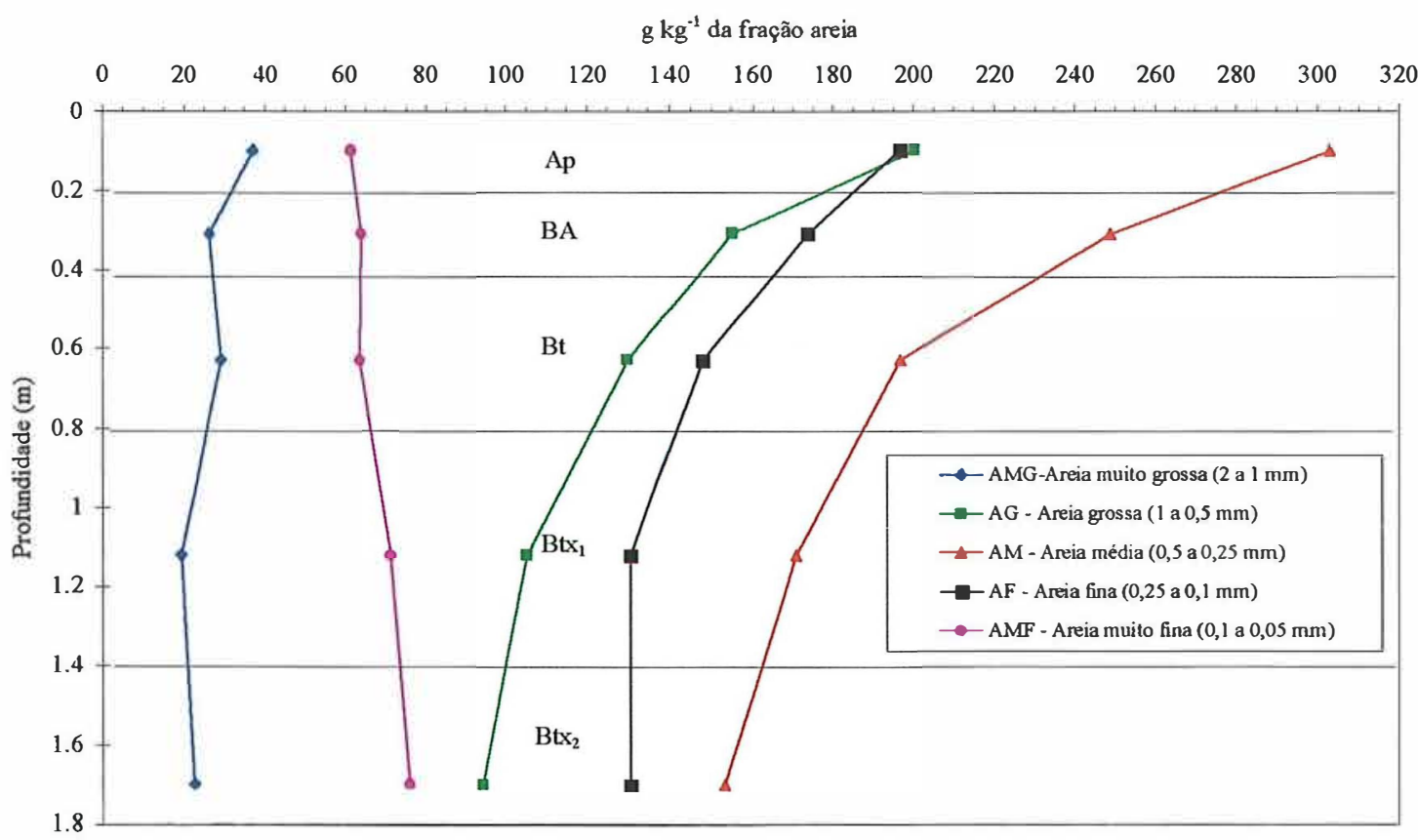

Figura 6 - Distribuição do tamanho das frações de areia, por profundidade.

A existência de uma camada coesa no solo estudado, que se apresentava como uma tendência na Figura 5, pode ser confirmada na Figura 7. Tomando-se como referência a densidade do solo do horizonte $\mathrm{Ap}\left(1,52 \mathrm{~kg} \mathrm{dm}^{-3}\right)$, observa-se na Figura $7 \mathrm{a}$ que houve um aumento em torno de $17 \%$ na densidade entre horizontes Ap e BA, permanecendo elevada no $\mathrm{Bt}$, o que caracteriza a presença de uma camada coesa bastante extensa com inicio a, aproximadamente, 0,2 $\mathrm{m}$ da superficie e término em algum ponto do Bt. Estes resultados combinam com as observações feitas por Jacomine (1996) de que o caráter coeso dos solos podzolizados além de estar presente logo abaixo do horizonte $\mathrm{A}$, pode atingir grande profundidade no B e que, as camadas coesas, estão, em geral, localizadas nos horizontes de transição. Da mesma forma, a camada coesa típica, descrita por Ribeiro (1991) abrange aproximadamente os 
horizontes de transição $\mathrm{AB}$ ou $\mathrm{BA}$ apresentando-se dura e compacta forçando as raízes, que se desenvolvem no horizonte sobreposto, a distribuirem-se horizontalmente.
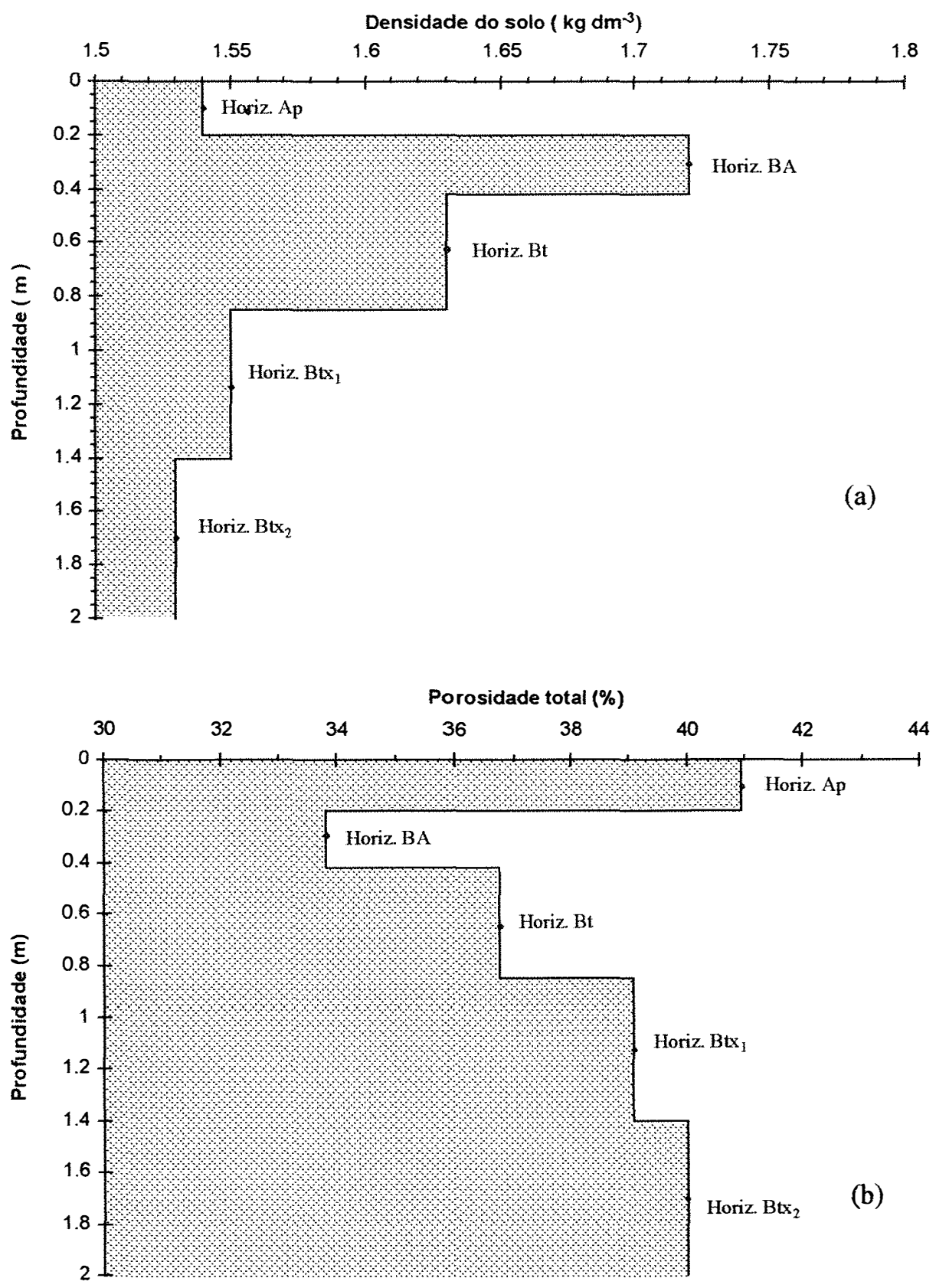

Figura 7 - Densidade do solo (a) e porosidade total calculada (b), por profundidade. 
$\mathrm{Na}$ Figura $7 \mathrm{~b}$ observa-se uma das principais consequências negativas da camada coesa no solo estudado a qual está relacionada aos seus efeitos sobre o volume total de poros. Verifica-se uma queda na porosidade total em torno de $10 \%$, entre os horizontes Ap e BA a qual representa redução de $24 \%$ na porosidade total entre estes horizontes, tomando-se como referência a porosidade de $41 \%$ do horizonte Ap. Esta redução no volume total de poros é acompanhada, provavelmente, de redução similar no percentual de macroporos, uma vez que, em solos adensados, os poros originalmente grandes, são comprimidos promovendo o aumento de poros de menor tamanho. Hillel (1970) ressalta, no entanto, que os microporos posicionados dentro dos agregados parecem ser inatingidos pelos processos que ocorrem no solo, somando-se aos que são criados quando ocorre adensamento, o que aumenta, desta forma, o volume total de poros muito pequenos nas camadas coesas. Vale ressaltar que qualquer alteração na porosidade afetará a atividade biológica e o movimento de água no solo, como também, a capacidade de retenção de água e sua disponibilidade para as plantas (Freitas \& Blacaneaux, 1988). É de se esperar portanto que a redução do espaço poroso observado na Figura $7 b$, tenha efeito marcante sobre o aumento da resistência mecânica do solo à penetração das raízes, durante a estação seca, e na baixa difusão de oxigênio durante a estação chuvosa, quando os microporos devem ficar cheios de água durante grande período de tempo.

\subsection{Sistema radicular}

A maior parte dos estudos sobre a distribuição do sistema radicular dos citros tem sido conduzida em solos profundos, sem impedimento mecânico e em ecossistema com precipitação pluvial bem distribuída durante todo o ano. Nessas condições o sistema radicular distribui-se, em geral, entre 0 e $1,5 \mathrm{~m}$ de profundidade com maior concentração das raízes entre 0,6 e 0,9 m (Jones \& Embleton, 1973; Shalhevet \& Levy, 1990; Oliveira, 1991). Vários trabalhos tem sido desenvolvidos para avaliar a distribuição das raízes nesta faixa de maior concentração a qual, em princípio, é da maior importância para ao suprimento de água e nutrientes às plantas. Em estudo conduzido por Mikhail \& El-Zeftawi (1979), apesar de 70\% das raizes estarem concentradas entre 
0 e 0,6 m, mais de um terço delas situavam-se entre 0,3 e $0,6 \mathrm{~m}$. Em outro trabalho, conduzido por Kurien et al. (1994), com o porta-enxerto Lima Ácida, foi encontrada como zona da maior atividade das raízes, a faixa de solo correspondente a $0,8 \mathrm{~m}$ de raio e profundidade entre 0,16 e $0,24 \mathrm{~m}$. Em São Paulo, trabalho desenvolvido por Pace \& Araújo (1986), para avaliar a distribuição das raízes de diferentes porta-enxertos, foi identificado grande redução no percentual de radicelas abaixo de $0,2 \mathrm{~m}$ como consequência, provavelmente, da mudança textural abrupta do solo podzolizado onde o pomar estava implantado.

As camadas adensadas, seja de origem genética, caso dos horizontes coesos dos tabuleiros costeiros, ou artificial, promovem na maioria das vezes, grandes alterações nos fatores fisicos do solo responsáveis pelo crescimento das plantas e, consequentemente, na configuração do sistema radicular das plantas. Nesse estudo, esta pressuposição pode ser comprovada na Figura 8 onde é possível verificar que a distribuição do sistema radicular dos cinco porta-enxertos de citros, em profundidade e lateralmente em relação ao tronco das laranjeira, diverge bastante da situação geralmente observada em solos profundos e sem camadas de impedimento. Observa-se que, independente do porta-enxerto, as raizes concentram-se nos primeiros $0,4 \mathrm{~m}$ de profundidade e na distância lateral de $2 \mathrm{~m}$, sendo inexpressiva a quantidade de raízes entre 0,4 e $1,2 \mathrm{~m}$ de profundidade e entre 2 e $3,4 \mathrm{~m}$ de distância do tronco. A quantificação em percentagem deste comportamento, representada na Figura 9, demonstra que $90 \%$ das raizes localizam-se nos primeiros $0,4 \mathrm{~m}$ do solo e que $61 \%$ do total do sistema radicular, nesta profundidade, estão distribuídos nos $0,2 \mathrm{~m}$ iniciais a partir da superficie do solo. Com relação à distribuição lateral, (Figura 10), verifica-se grande homogeneidade na distribuição das raizes ao longo de $2 \mathrm{~m}$ em relação ao tronco da laranjeira em cujo intervalo de distância, estão concentradas $90 \%$ das raizes. 


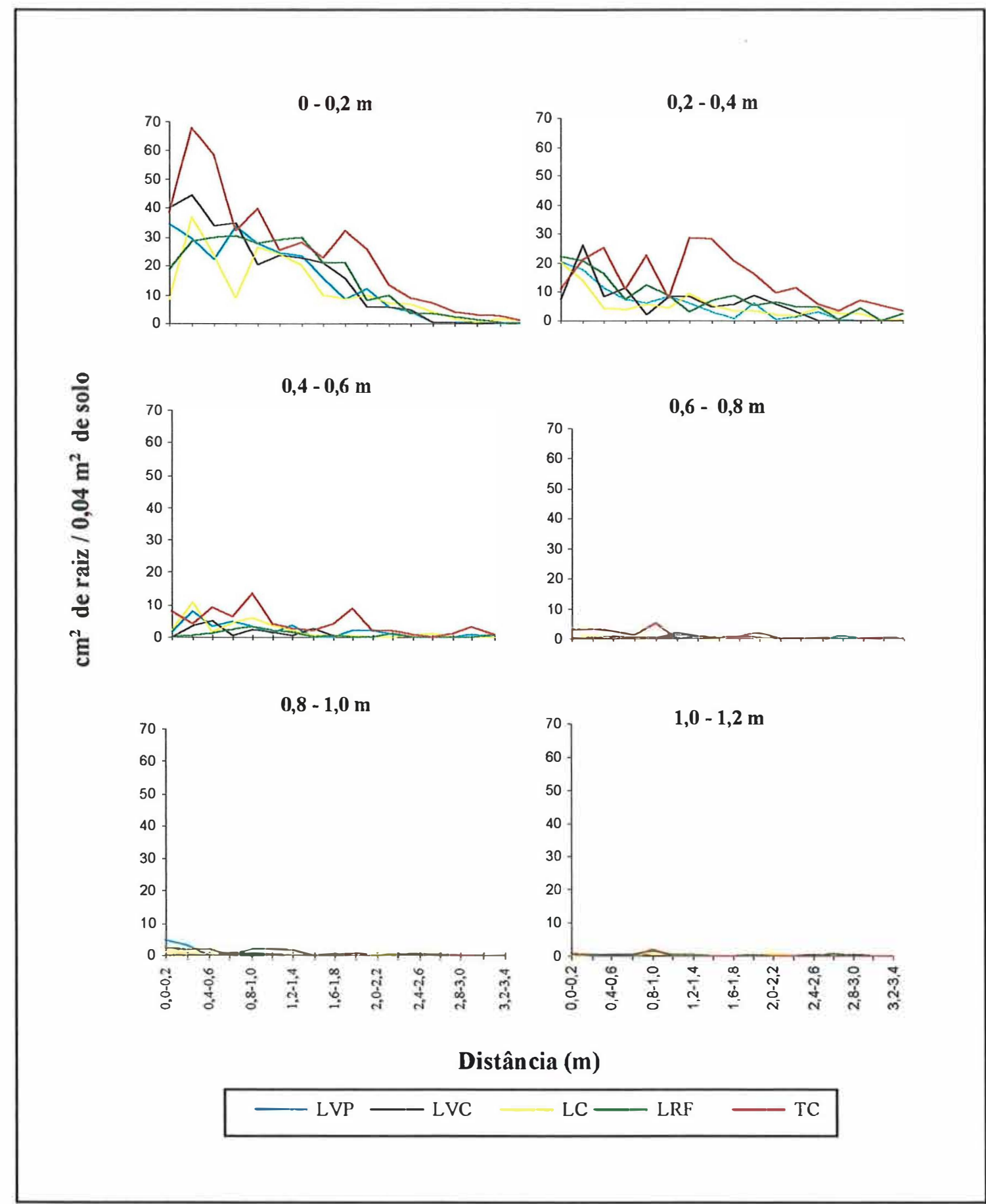

Figura 8 - Distribuição do sistema radicular dos porta-enxertos, em função da distribuição lateral das raizes, em relação ao tronco da laranjeira, por profundidade (camadas de solo de $0,2 \mathrm{~m}$ ). 


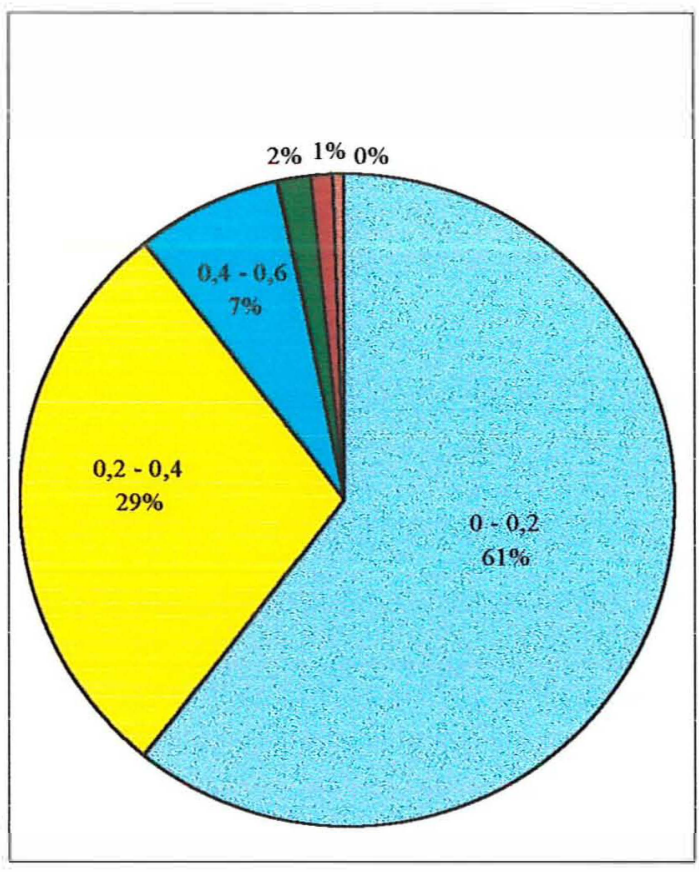

Figura 9 -Distribuição das raizes/profundidade

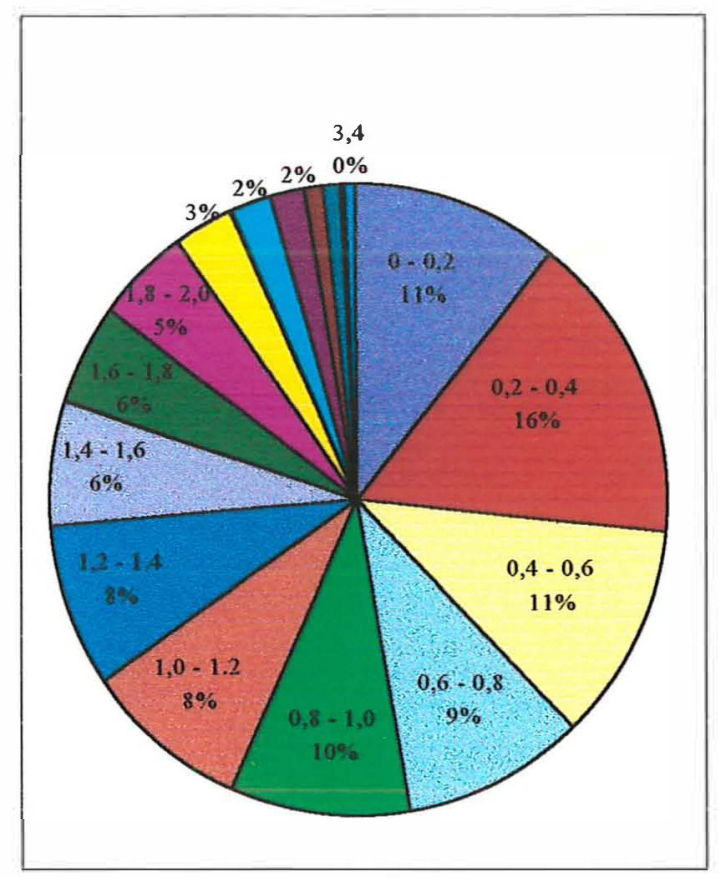

Figura 10 -Distribuição das raizes / distância

Com base na constatação de que, em torno de $90 \%$ das raízes estavam localizadas na área correspondente a $0,4 \mathrm{~m}$ de profundidade e $2 \mathrm{~m}$ de distância do tronco sendo esta, portanto, a faixa de solo com maior concentração de raízes e, consequentemente, mais representativa para todos os porta-enxertos avaliados, decidiu-se pela análise detalhada dos dados, apresentação e discussão dos resultados relativos à área de $1 \mathrm{~m}^{2}(0,5 \mathrm{~m} \mathrm{x} \mathrm{2,0} \mathrm{m)} \mathrm{apenas} \mathrm{a} \mathrm{esta} \mathrm{região} \mathrm{onde} \mathrm{efetivamente} \mathrm{as} \mathrm{raízes} \mathrm{se} \mathrm{distribuem.}$ Com base nesta nova avaliação verifica-se na Figura 11, que, de maneira geral, a distribuição das raízes em relação à profundidade do solo, independente do porta-enxerto utilizado, é caracterizada pela intensa superficialização das raízes e alta concentração nos primeiros $0,1 \mathrm{~m}$ a partir da superficie, cuja camada de solo detêm em torno de $50 \%$ de todo o sistema radicular da planta. A análise detalhada dessa faixa permitiu identificar, com maior precisão, as diferenças existentes entre os porta-enxertos avaliados e entre as camadas de solo estudadas até a profundidade de $0,5 \mathrm{~m}$. 


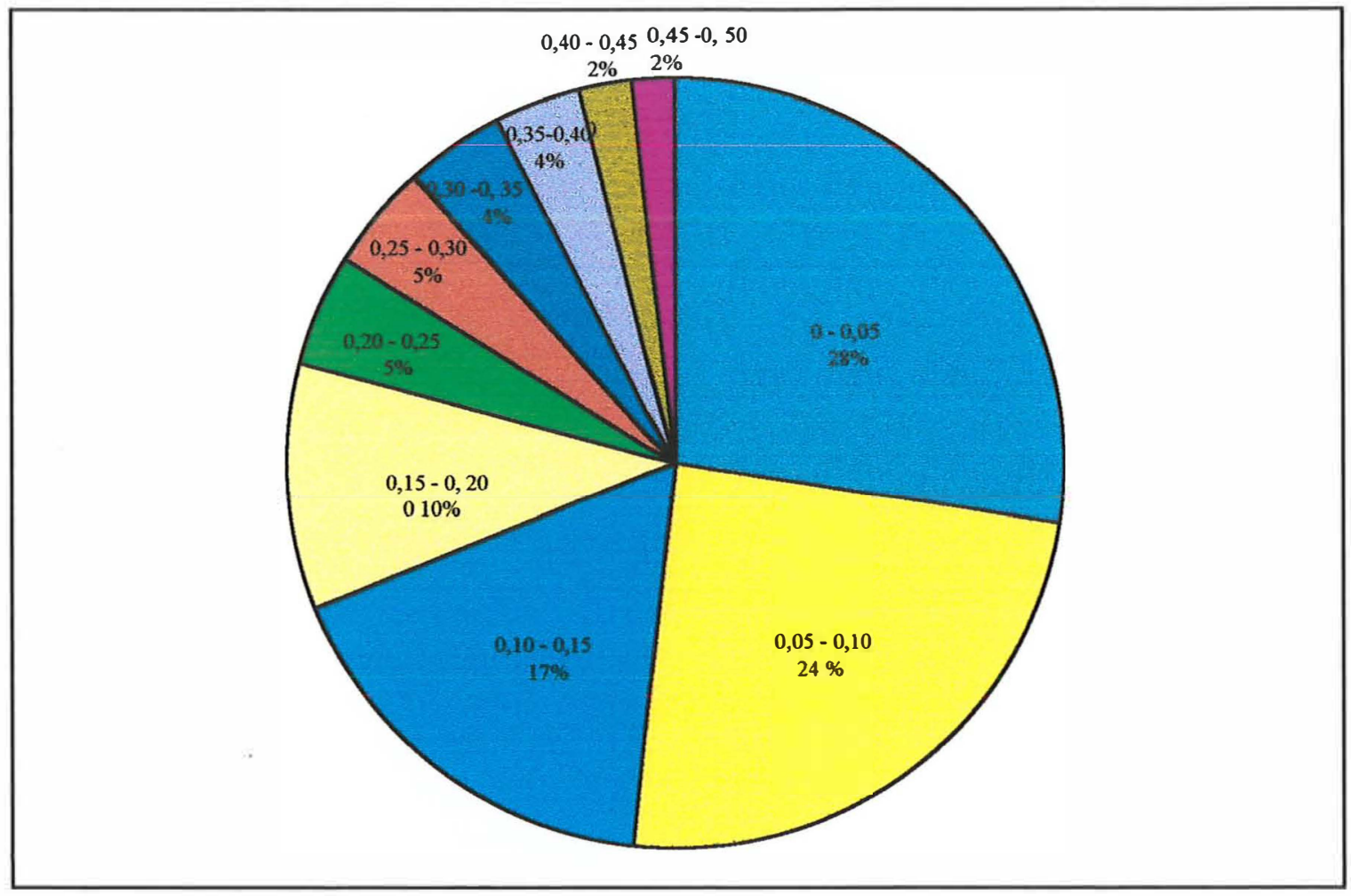

Figura 11 -Distribuição do sistema radicular, por profundidade (m), independente do porta-enxerto avaliado (camadas de solo de $0,1 \mathrm{~m}^{2}(0,05 \mathrm{~m} \times 2 \mathrm{~m})$ )

Os resultados da análise de variância, apresentados na Tabela 5, demonstram ter havido diferença significativa para os fatores isoladamente, sendo de $5 \%$ de significância entre porta-enxertos e de $1 \%$ entre profundidades, além da ausência de interação o que demonstra total independência entre os fatores tanto para a variável área como para comprimento de raízes. Outro fato a destacar é a grande similaridade entre as variáveis área e comprimento de raízes o que possibilita a escolha de uma delas para apresentação dos resultados. Optou-se pela variável comprimento pelos motivos que serão expostos a seguir.

Segundo Weller (1971) a variável comprimento de raízes dá uma melhor idéia da distribuição das zonas absorventes do sistema radicular do que o critério de massa além de ser uma medida mais sensível às variações climáticas. De acordo com este este autor, nas avaliações feitas tendo como base a massa total das raízes, uma elevada massa não indica, necessariamente, uma zona com alta capacidade de absorção 
de água e nutrientes, especialmente para plantas perenes onde grande parte do sistema radicular é lenhoso e pesado. Interpretação similar a esta, pode ser feita com relação às medições tendo como base a área de raízes por área de solo. Da mesma forma que no critério de massa, nem sempre o peso total de raizes representa uma região de grande atividade, no critério de área, uma grande área pode refletir uma zona de baixa atividade. Nas medições feitas tendo como base o comprimento, no entanto, a padronização das raízes para um mesmo tamanho de pixel, possibilitada pelo SIARCS, permite uniformizar o diâmetro de todas as raizes dando, desta forma, maior representatividade da medida quanto à capacidade de absorção de água e nutrientes de um determinado volume de raízes a determinada distância do tronco e profundidade do solo.

Tabela 5 - Análise da variância para área e comprimento de raízes por quadrícula em $\mathrm{m}^{2}$ e $m$, respectivamente.

\begin{tabular}{|c|c|c|c|c|c|c|c|}
\hline \multirow{2}{*}{$\begin{array}{l}\text { Causas de } \\
\text { Variação }\end{array}$} & \multirow[t]{2}{*}{ GL } & \multicolumn{2}{|c|}{ Quadrado Médio } & \multicolumn{2}{|c|}{ Valor $\mathbf{F}$} & \multicolumn{2}{|c|}{ Prob. $>$ F } \\
\hline & & Área & Compr. & Área & Compr. & Área & Compr. \\
\hline Bloco & 2 & & & & & & \\
\hline Porta-enxerto (PE) & 4 & 0,0000605 & 7,972 & 6,749 & 5,977 & $0,011^{*}$ & $0,016^{*}$ \\
\hline Residuo (A) & 8 & 0,0000090 & 1,334 & & & & \\
\hline Parcelas & 14 & & & & & & \\
\hline Profundidade (Prof.) & 9 & 0,0001781 & 23,786 & 23,229 & 18,530 & $0,00001 * *$ & $0,00001^{* *}$ \\
\hline PE x Prof. & 36 & 0,0000042 & 0,5376 & 0,543 & 0,419 & $0,9790 \mathrm{~ns}$ & $0,9980 \mathrm{~ns}$ \\
\hline Residuo (B) & 90 & 0,0000077 & 1,284 & & & & \\
\hline \multirow[t]{2}{*}{ TOTAL } & 149 & & & & & & \\
\hline & & Área & Comprimento & & & & \\
\hline Média Geral & & 0,0038 & 1,3187 & & & & \\
\hline Coef. Variação (A) & & $24 \%$ & $28 \%$ & & & & \\
\hline Coef. Variação (B) & & $72 \%$ & $85 \%$ & & & & \\
\hline
\end{tabular}

Com relação aos resultados da distribuição das raízes por camada de solo, o estudo da regressão polinomial, para os niveis de profundidade, demonstrou serem significativas as regressões linear e quadrática a $1 \%$ de significância. Os resultados apresentados na Figura 12 possibilitam verificar o grande relacionamento entre comprimento de raízes e profundidade do solo para todos os porta-enxertos avaliados. 
Na Figura 12a onde toda a camada de $0,5 \mathrm{~m}$ é avaliada, verifica-se que a distribuição dos pontos tem dois comportamentos distintos, sendo uma distribuição uniforme até $0,25 \mathrm{~m}$ e outra também uniforme, porém quantitativamente muito inferior, a partir desta profundidade até $0,5 \mathrm{~m}$. Essa observação levou ao estudo da regressão polinomial para estas duas situações, cujos resultados são apresentados nas Figuras 12b e 12c. Em ambas figuras verifica-se que o coeficiente de regressão linear é negativo indicando que as variáveis comprimento de raízes e profundidade do solo, estão correlacionados negativamente, variando em sentido oposto, ou seja: à medida que aumenta a profundidade do solo, menor é a concentração de raízes. O coeficiente de correlação linear de Pearson (r) ao redor de 99\%, indica forte relacionamento entre as variáveis da mesma forma que o coeficiente de determinação $\left(R^{2}\right)$ demonstra pequena variação total dos dados.

As inclinações diferenciadas entre as retas de regressão das Figura 12b e 12c confirmam a existência de redução abrupta na concentração das raízes nos primeiros $0,25 \mathrm{~m}$, cuja densidade cai de 380 para $50 \mathrm{~cm}$ de raiz por $0,1 \mathrm{~m}^{2}$ de solo, o que representa uma queda, em torno de $85 \%$ (Figura 12b). Nos últimos 0,25 m (Figura 12c) além da baixa amplitude entre os dados, a inclinação da reta próxima a zero dá uma idéia dos baixos valores de densidade de raízes nesta faixa de solo. Uma observação de grande importância, visualizada na Figura 12a, diz respeito à possibilidade de identificação do momento exato em que os pontos da curva tomam novo direcionamento (camada de solo entre 0,2 e 0,25 m), dando indicação clara da existência de algum fenômeno atuando na distribuição do sistema radicular, em profundidade. 


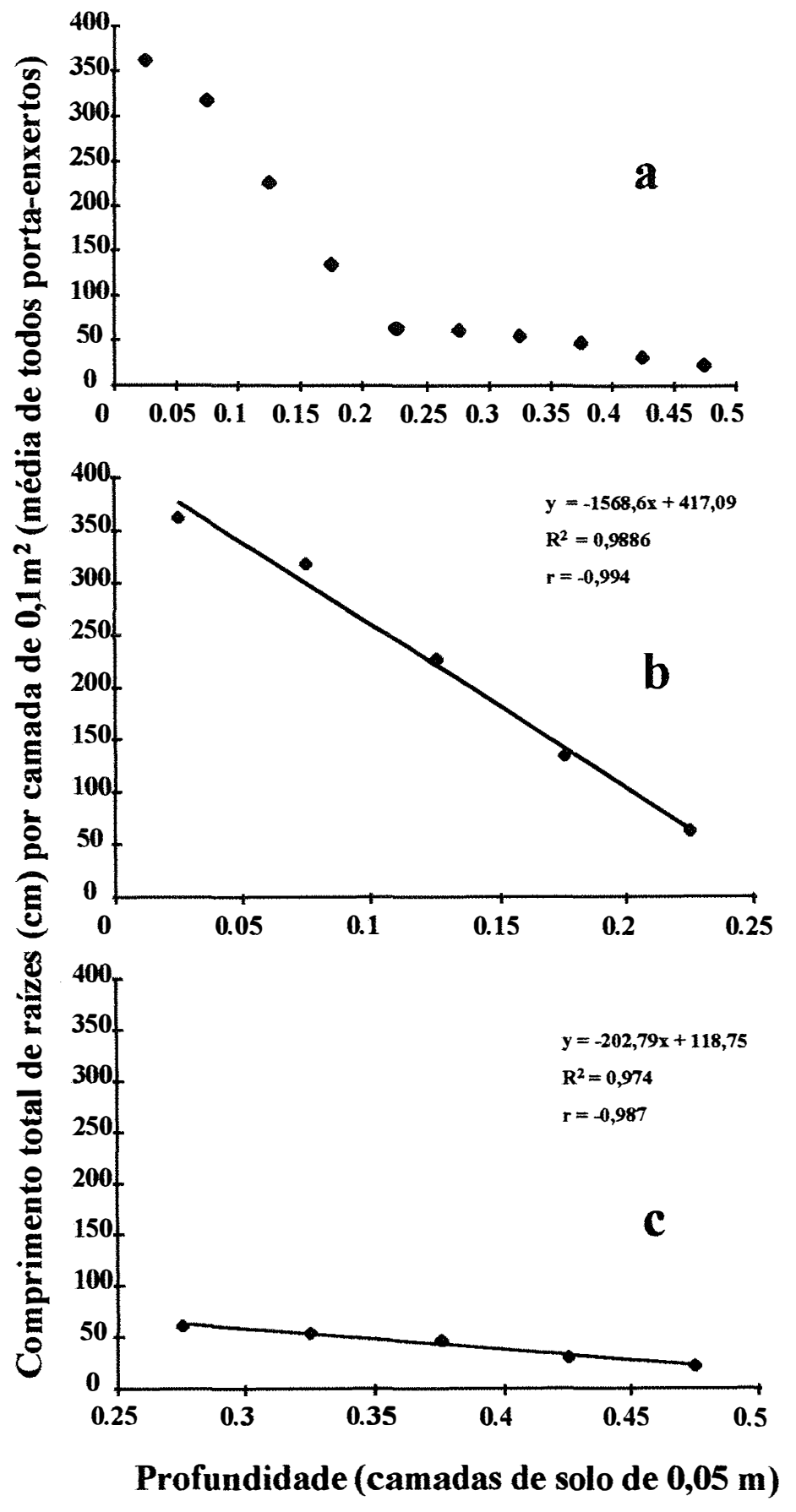

Figura 12 -Relação entre densidade de raizes e profundidade do solo: a) entre 0 e $0,5 \mathrm{~m}, \mathrm{~b}$ ) entre 0 e $0,25 \mathrm{~m}, \mathrm{c}$ ) entre 0,25 e $0,5 \mathrm{~m}$ 
A interpretação física deste fenômeno está, provavelmente relacionada à presença da camada coesa próxima à superficie do solo, e, à sua extensão de aproximadamente $0,6 \mathrm{~m}$ (Figura 7). É possível que a grande extensão da camada coesa seja responsável em parte pela baixa concentração das raizes ao longo de toda a faixa de solo abaixo de $0,25 \mathrm{~m}$. Quanto à elevada concentração das raízes nos primeiros $0,25 \mathrm{~m}$ do solo pode ser consequência não só da alta resistência mecânica da zona coesa, que impede a penetração das raízes durante o período seco, como também, da má aeração que ocorre acima desta camada durante o período chuvoso, impedindo que as raízes se aprofundem no solo quando a resistência mecânica deixa de atuar. Situações similares a esta tem sido observadas por muitos autores, em diversas culturas, variando apenas em intensidade e assumem grande relevância, principalmente, nas culturas perenes as quais são submetidas a grandes variações climáticas durante seu ciclo de vida.

As pesquisas para avaliação de porta-enxertos de citros quanto à adaptação a diferentes ecossistemas é tema recorrente na citricultura onde grande parte dos trabalhos está relacionada à busca de materiais com sistema radicular profundo, característica esta a qual, tem-se atribuído grande importância como mecanismo de tolerância a déficits hídricos. As hipótese testadas com o objetivo de comprovar ou rejeitar as várias indagações formuladas sobre este tema são as mais diversas possiveis porém, na maioria das vezes, envolvem solos profundos e sem camadas de impedimento. A abordagem em solos com problemas de drenagem causados pela presença de camadas de solos com elevado nível de adensamento, tem sido restrita e, nesses casos, evidentemente, outros fatores devem ser considerados em virtude das alterações impostas na aeração e resistência mecânica do solo. Com relação à cultura dos citros em especial, Castle et al (1989) enfatiza a vulnerabilidade desta cultura aos rigores climáticos, principalmente, quando o sistema radicular das plantas fica restrito a um pequeno volume de solo, próximo à superficie. Oliveira (1991) chama à atenção para a elevada sensibilidade desta cultura à má aeração e difusão dos gases no solo e alerta que, nessas condições, o sistema radicular chega, muitas vezes, a paralisar por completo o seu 
crescimento. Diferenças entre porta-enxertos quanto à tolerância à má aeração do solo foram encontradas por Hagin et al. (1965) os quais ressaltam a maior vulnerabilidade do Citrus limettioides (Lima da Pérsia) em relação ao Citrus aurantium (laranja Azeda) quanto às variações nos teores de $\mathrm{O}_{2}$.

Nesta pesquisa foram observadas diferenças entre os porta-enxertos avaliados não só quanto à configuração do sistema radicular como um todo, como também, quanto à tendência para aprofundamento de suas raízes. As diferenças mais marcantes ficaram a cargo da Tangerina Cleópatra e do Limão Cravo respectivamente, os quais apresentaram a maior e a menor densidade de raízes tanto lateralmente (Figura 13), como em profundidade (Figura 14) sendo que, apenas a Tangerina

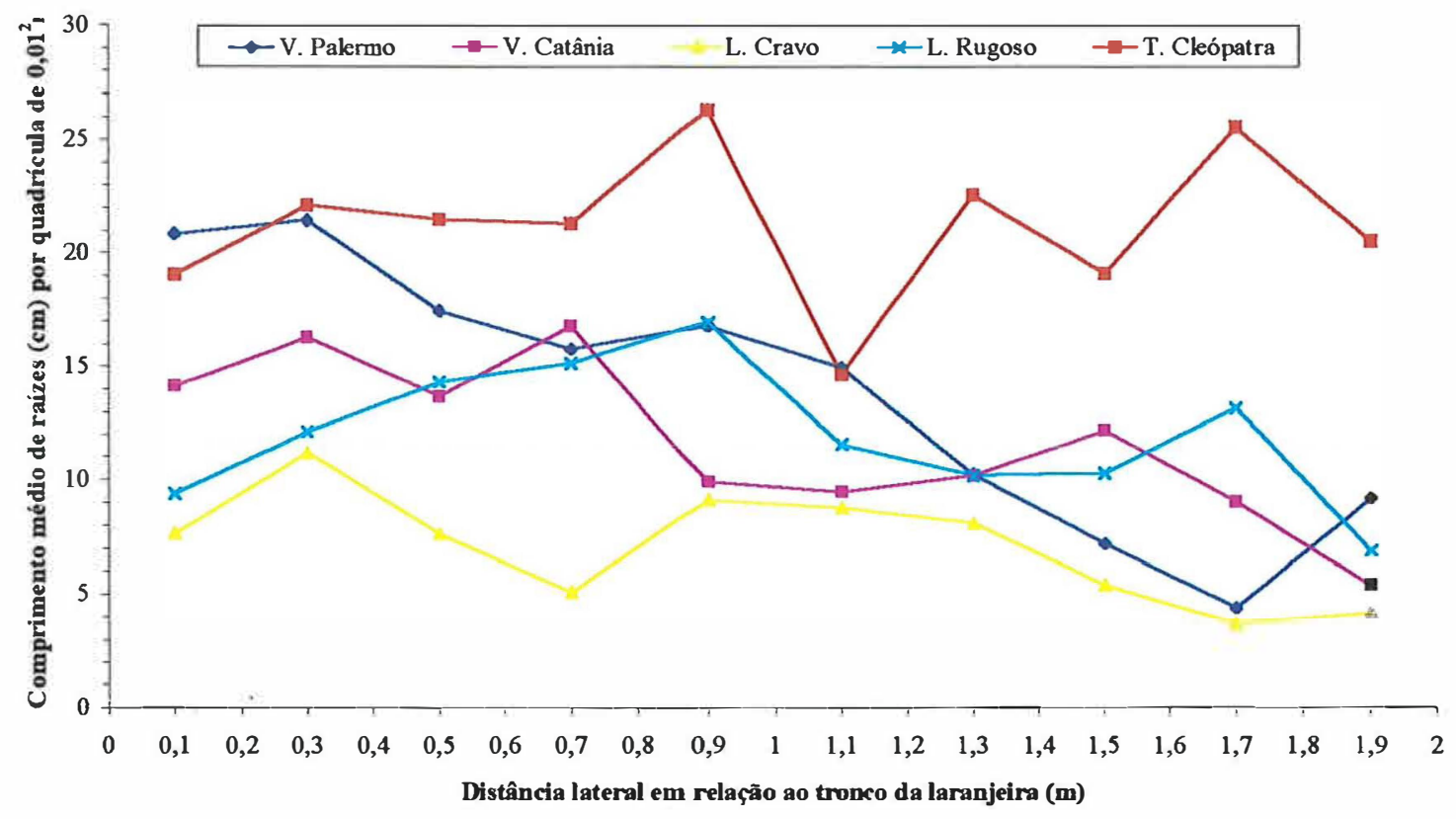

Figural3 - Distribuição lateral do sistema radicular dos porta-enxertos avaliados.

Cleópatra diferiu significativamente de todos materiais. Quanto à distribuição lateral da raízes, verifica-se na Figura 13 comportamento homogêneo ao longo dos $2 \mathrm{~m}$ para os 
porta-enxertos Limão Cravo, Limão Rugoso da Flórida e Tangerina Cleópatra e leve tendência, porém não significativa, de redução da densidade das raízes com a distância, por parte dos Volcamerianos. Em profundidade, Figura 14, é visível a concentração das raízes nos $0,2 \mathrm{~m}$ iniciais da superficie do solo em todos os materiais à exceção da Tangerina Cleópatra que se sobressai sobre os demais não só quanto à maior densidade, como também, quanto ao maior volume de raízes em profundidade. Vale destacar o valor observado da densidade das raízes deste porta-enxerto entre 0,2 e 0,4 m de profundidade, o qual supera o valor no limite superior da zona coesa e chega a ser próximo da quantidade de raízes produzida pelo Limão Cravo nos $0,2 \mathrm{~m}$ iniciais do solo. Como esta reação só é percebida na Tangerina Cleópatra, pode-se inferir que este material apresenta capacidade de penetração do sistema radicular, na zona coesa, levemente superior à dos outros porta-enxertos.

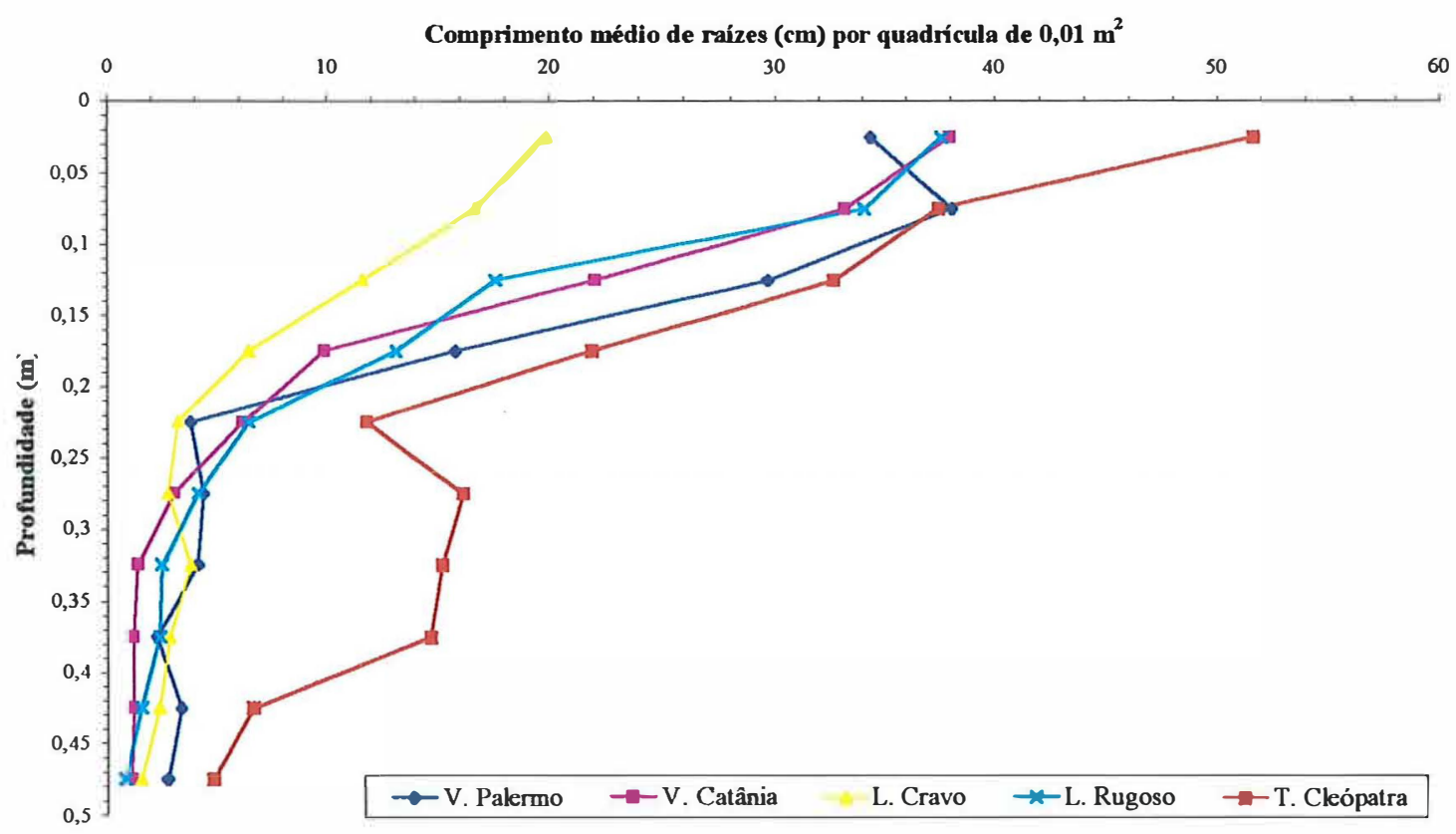

Figura 14-Distribuição em profundidade do sistema radicular dos porta-enxertos avaliados, independente da distância lateral.

A tendência para aprofundamento ou superficialização do sistema radicular dos porta-enxertos avaliados, independente da quantidade de raízes produzida, pode ser 
melhor percebida na Figura 15 ao se fixar a profundidade de $0,2 \mathrm{~m}$ a partir da superficie do solo (os quatro primeiros segmentos do gráfico de torta). Verifica-se que a concentração de raízes nesta camada de solo é de $67,76,84,85$ e $87 \%$ para os portaenxertos Tangerina Cleópatra, Limão Cravo, Limão Volcameriano Palermo, Limão Rugoso da Flórida e Limão Volcameriano Catânia, respectivamente. Este fato pode ser uma indicação de que a Tangerina Cleópatra e o Limão Cravo apresentam maior capacidade para aprofundamento do sistema radicular pois, enquanto 33 e $24 \%$ das raizes destes porta-enxertos, respectivamente, situam-se abaixo de 0,2 $\mathrm{m}$, o percentual dos demais, abaixo desta camada situa-se ao redor de $15 \%$. O maior potencial para aprofundamento das raízes apresentado pelo porta-enxerto Tangerina Cleópatra, foi ressaltado por Castle \& Krezdorn (1973) os quais obtiveram uma relação positiva entre a copa e a profundidade de enraizamento. Os autores concluíram que os materiais de porte elevado, como o deste porta-enxerto, apresentam, em geral, sistema radicular mais profundo estando este fato associado a uma maior capacidade para suprimento de água e nutrientes à parte aérea da planta.

A característica para aprofundamento das raízes, no entanto, nem sempre deve estar associada a uma maior tolerância das plantas aos déficits hídricos. A depender do ecossitema, caso dos dos tabuleiros costeiros onde o regime climático submete as plantas a um período contínuo de cinco a seis meses com déficit hídrico o maior volume de raizes apresentado pela Tangerina Cleópatra pode trazer consequências mais negativas do que positivas. $\mathrm{O}$ grande volume de raizes produzido por este portaenxerto pode promover por exemplo o esgotamento mais rápido das reserva de água no solo submetendo as plantas mais precocemente ao estresse hídrico. Nestas circunstâncias, é provável que porta-enxertos com sistema radicular mais restrito e melhor distribuído em profundidade, características observadas nesse estudo no Limão Cravo, apresentem melhor resposta aos déficits hídricos. A performance do Limão Cravo observada após grande período de seca, em solos podzolizados (Castro, 1995) pode estar relacionada às características de distribuição do sistema radicular deste porta-enxerto. 


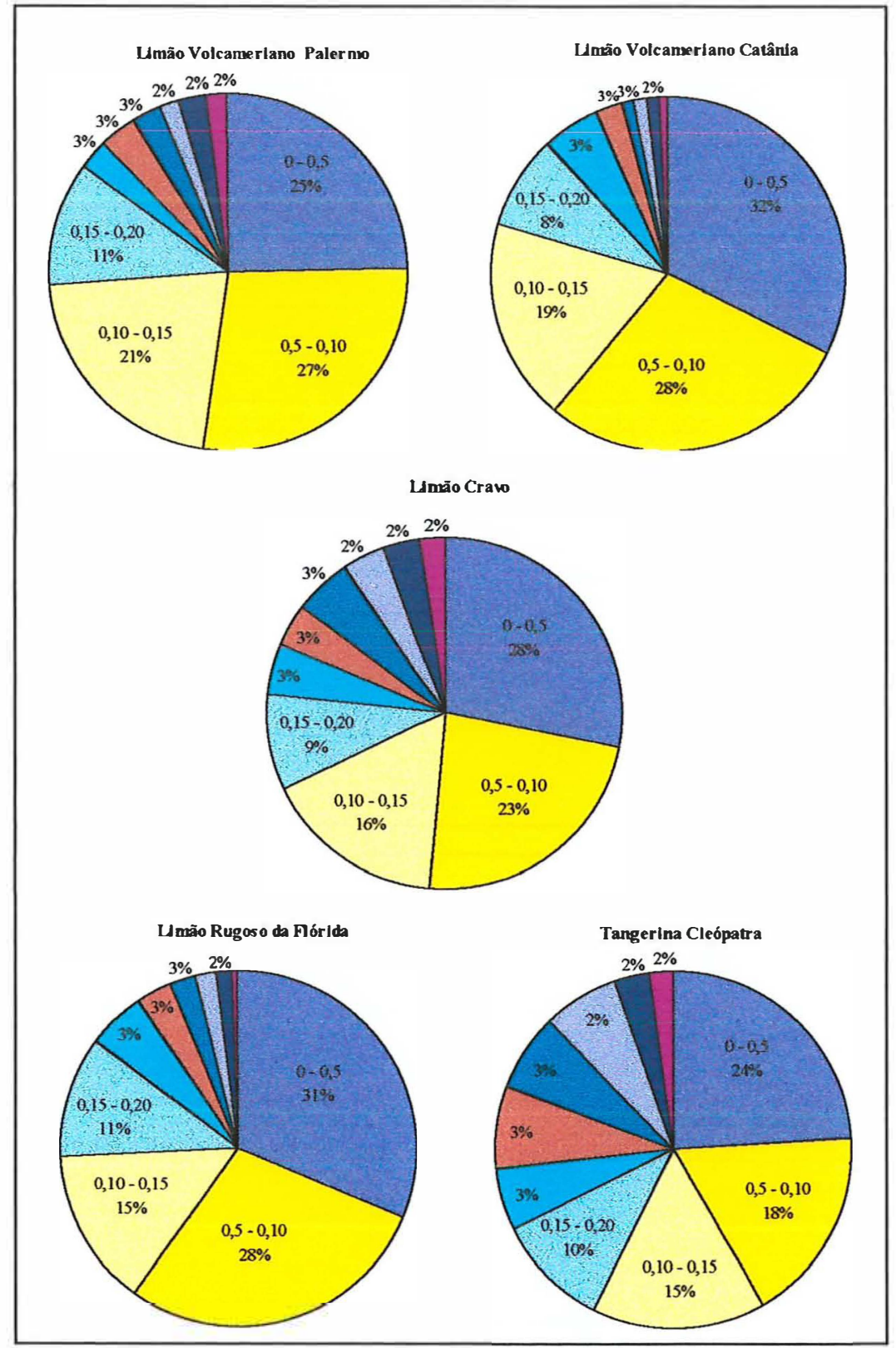

Figura 15 - Distribuição do sistema radicular por camada de solo de $0,1 \mathrm{~m}^{2}$ até a profundidade de $0,5 \mathrm{~m}$.

Além das características genéticas e da presença de zonas superficiais de adensamento um outro problema que pode contribuir para a superficialização do sistema radicular dos porta-enxertos de citros, pode estar associado à prática de poda das raízes, comumente realizada por ocasião do transplante das mudas, a qual, na maioria das vezes, inibe a formação de uma raiz principal típica. Segundo Reuther (1973) a raiz 
primária dos citros só cresce reta e orientada para baixo se não for danificada no transplante. Da mesma forma, Tuzcu et al. (1981) atribuem à orientação da raíz primária a maior ou menor capacidade de aprofundamento das raízes dos porta-enxertos de citros. Segundo estes autores, o material que apresentar raíz pivotante com pouca ramificação lateral tem maiores chances de aprofundar o sistema radicular, sobrevivendo melhor tanto às condições de má aeração como de déficit de água. Neste trabalho não foi observada a formação de raíz principal em nenhum dos porta-enxertos estudados, fato este, atribuído à prática referida de poda das raízes, por ocasião do transplante do viveiro para o plantio definitivo.

\subsection{Movimento de água no solo}

Em muitas unidades geoambientais do ecossistema dos tabuleiros costeiros a dinâmica da água assume características peculiares por estarem envolvidos nos processos de drenagem e redistribuição uma série de fatores restritivos (heterogeneidade dos horizontes e presença de camadas coesas próximas à superficie) além do regime hídrico caracterizado pela concentração das chuvas por um período de cinco a seis meses contínuos. $\mathrm{Na}$ unidade geoambiental estudada, este conjunto de características assume grande relevância por colocar em risco o crescimento e a produtividade dos citros cuja exploração representa, como já abordado, uma das principais atividades agrícolas do Estado de Sergipe. Estes riscos estão relacionados, principalmente, ao suprimento de água e atingem a cultura com grande intensidade durante o período seco quando as reservas de água na camada superficial, onde está concentrada a quase totalidade do sistema radicular, chega a níveis críticos promovendo danos, muitas vezes irreversíveis, ao crescimento e desenvolvimento das plantas. Apesar deste quadro, é comum encontrar nessa região pomares com desenvolvimento e produtividade compativeis com explorações de sequeiro bem manejadas. Este fato, leva à pressuposição de que a interação entre os fatores que compõem o ecossistema pode, muitas vezes, superar as limitações que, teoricamente, retringiriam a atividade agrícola 
nesta região. Os resultados apresentados a seguir buscam respostas para estas e outras indagações relacionadas à dinâmica da água no solo em ecossistema de tabuleiro costeiro

\subsubsection{Retenção de água}

A aplicação da teoria do fluxo de água em solo não saturado tanto no campo como em laboratório requer o conhecimento da condutividade hidráulica e das características de retenção da água no solo (Klute, 1972). Dentre as alternativas para medição do fluxo proposto pelo autor, encontra-se a utilizada neste trabalho onde o teor de água no solo foi estimado com base na curva de retenção de água a partir dos potenciais mátricos obtidos no campo. Além desta utilização, primordial para caracterização do movimento de água no solo, as curvas de retenção permitem realizar inferências importantes sobre as características do solo e seu comportamento hidráulico.

$\mathrm{Na}$ Tabela 6 e Figura 16 é possível observar comportamento bastante diferenciado entre os horizontes quanto à retenção de água. Enquanto nos horizonte Ap e $\mathrm{Btx}_{2}$ as curvas tem maior declividade em relação aos outros horizontes, o que significa queda mais acentuada no teor de água com o aumento da tensão aplicada, as curvas dos horizontes $\mathrm{BA}, \mathrm{Bt}$ e $\mathrm{Btx}_{1}$ são mais suaves denotando redução gradual da umidade com o aumento da tensão. Estas diferenças exercem grande influência no comportamento hidráulico do solo e estão, provavelmente, associadas à distribuição do tamanho das partículas do solo e à estrutura de cada horizonte.

Tabela 6 - Valores medidos da curva de retenção de água, por horizonte.

\begin{tabular}{cccccc}
\hline \multirow{2}{*}{$\begin{array}{c}\text { Tensões } \\
(\mathrm{kPa})\end{array}$} & $\mathbf{A p}$ & $\mathbf{B A}$ & $\mathbf{B t}$ & $\mathbf{B t x} \mathbf{1}$ & $\mathbf{B t x 2}$ \\
\cline { 2 - 6 } & 0,500 & 0,350 & 0,400 & 0,420 & 0,500 \\
0,0 & 0,494 & 0,346 & 0,383 & 0,414 & 0,451 \\
0,5 & 0,344 & 0,332 & 0,350 & 0,387 & 0,409 \\
1 & 0,224 & 0,264 & 0,280 & 0,341 & 0,348 \\
4 & 0,178 & 0,248 & 0,269 & 0,296 & 0,324 \\
7 & 0,166 & 0,234 & 0,252 & 0,271 & 0,287 \\
10 & 0,154 & 0,192 & 0,238 & 0,266 & 0,254 \\
30 & 0,123 & 0,174 & 0,224 & 0,254 & 0,229 \\
80 & 0,116 & 0,145 & 0,215 & 0,245 & - \\
100 & 0,089 & 0,141 & 0,204 & 0,230 & 0,195 \\
500 & 0,074 & 0.135 & 0.190 & 0.220 & 0,175 \\
1500 & & & &
\end{tabular}



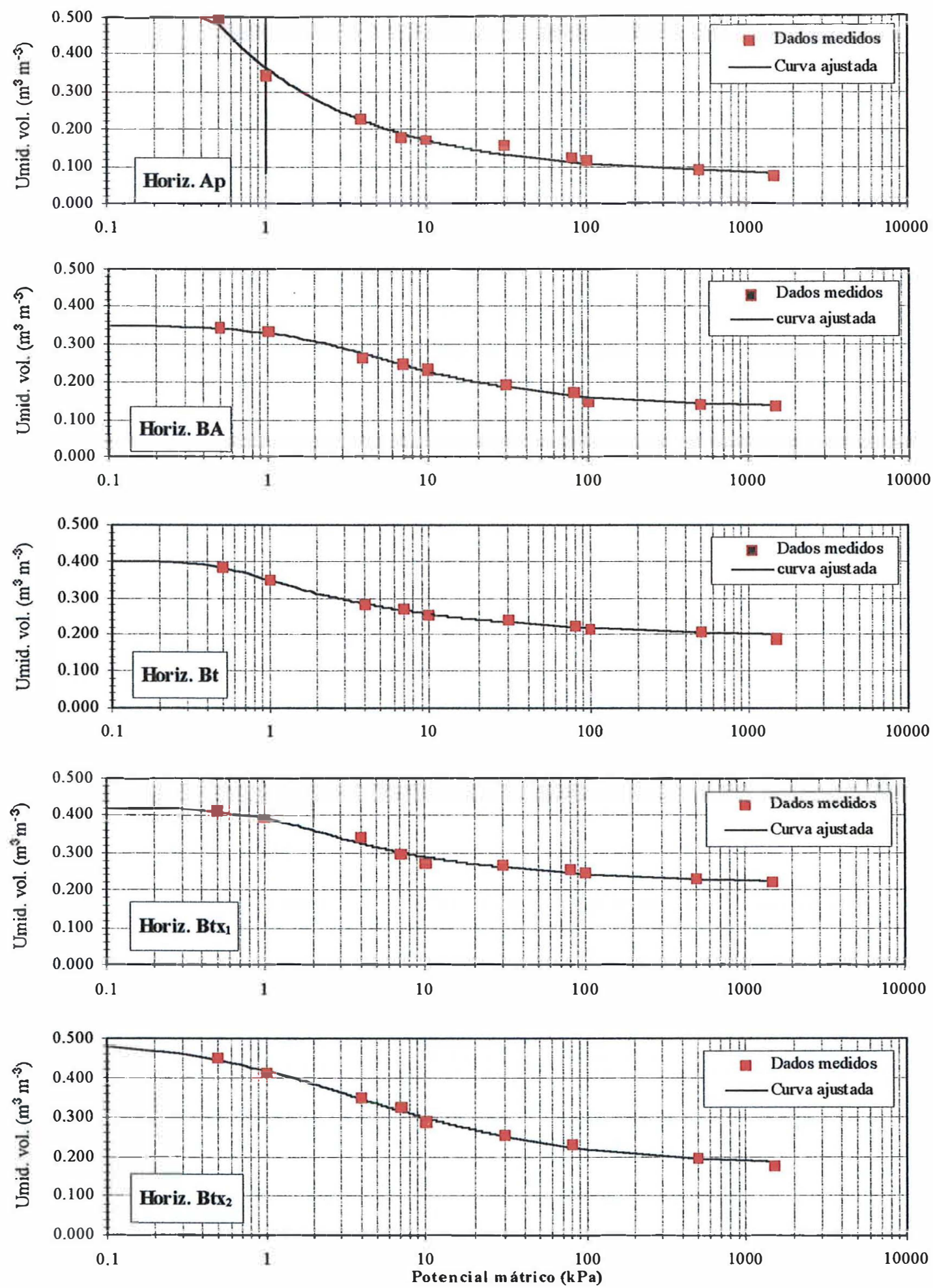

Figura 16 - Curvas de retenção de água, por horizonte na área experimental. 


\subsubsection{Condutividade hidráulica}

Na Tabela 7 estão apresentadas as equações representativas da condutividade hidráulica (K), obtidas com base no método desenvolvido por Libardi et al (1980), as quais descrevem o comportamento hidráulico do solo com base no modelo $K=K_{0} \exp ^{\beta\left(\theta-\theta_{0}\right)}$ onde $K_{0}$ e $\theta_{0}$ representam, no presente caso, a condutividade e a umidade do solo no tempo zero $\left(\mathrm{t}_{0}\right)$ obtido a campo e $\beta$ o coeficiente angular da curva de $\theta$ versus logarítimo neperiano $(\ln )$ do tempo, por profundidade.

Tabela 7. Equações representativas da condutividade hidráulica

\begin{tabular}{cccccc}
\hline Horiz. & Prof. & \multicolumn{3}{c}{ Parâmetros teóricos } & Equações \\
\hline Ap & 0,1 & $\theta_{\mathbf{o}}\left(\mathbf{m}^{\mathbf{3}} \mathbf{~ m}^{-3}\right)$ & $\mathbf{K}_{\mathbf{0}}\left(\mathbf{m} \mathbf{d i a}^{-1}\right)$ & $\beta$ & \\
BA & 0,307 & 0,0546 & 57,143 & $\mathrm{~K}=0,0546 \exp ^{57,143(\theta-0,307)}$ \\
$\mathrm{Bt}$ & 0,3 & 0,350 & 0,0679 & 57,143 & $\mathrm{~K}=0,0679 \exp ^{57,143(\theta-0,350)}$ \\
& 0,5 & 0,400 & 0,0340 & 23,095 & $\mathrm{~K}=0,0340 \exp ^{23,095(\theta-0,400)}$ \\
Btx $_{1}$ & 0,7 & 0,400 & 0,0440 & 28,571 & $\mathrm{~K}=0,0440 \exp ^{28,571(\theta-0,400)}$ \\
& 0,9 & 0,420 & 0,0418 & 29,155 & $\mathrm{~K}=0,0418 \exp ^{29,155(\theta-0,420)}$ \\
& 1,1 & 0,416 & 0,0505 & 32,258 & $\mathrm{~K}=0,0505 \exp ^{32,258(\theta-0,416)}$ \\
Btx $_{2}$ & 1,3 & 0,419 & 0,0662 & 37,736 & $\mathrm{~K}=0,0662 \exp ^{37,736(\theta-0,419)}$ \\
\hline
\end{tabular}

O comportamento hidráulico do solo é ilustrado na Figura 17, para cada camada de solo apresentada separadamente, onde é possível perceber as variações na condução da água ao longo do perfil. Em geral as diferenças e semelhanças observadas na condutividade hidráulica estão relacionadas às características físicas de cada camada $\mathrm{e}$ estão associadas, principalmente, à distribuição do tamanho das partículas, estrutura, distribuição do tamanho dos poros, espaço poroso total e geometria dos poros. Nye \& Thinker (1977) alertam que a magnitude da condutividade hidráulica na camada superficial do solo está relacionada ao grau de compactação e às mudanças estruturais promovidas pelas práticas de preparo do solo. Klute \& Dirksen (1986) observam que quando o conteúdo de água decresce da saturação, os poros grandes, que são os mais efetivos na condução da água, são os primeiros a drenar. Este fato, junto com o aumento da tortuosidade, contribui para o rápido decréscimo da condutividade com a diminuição do conteúdo de água. 

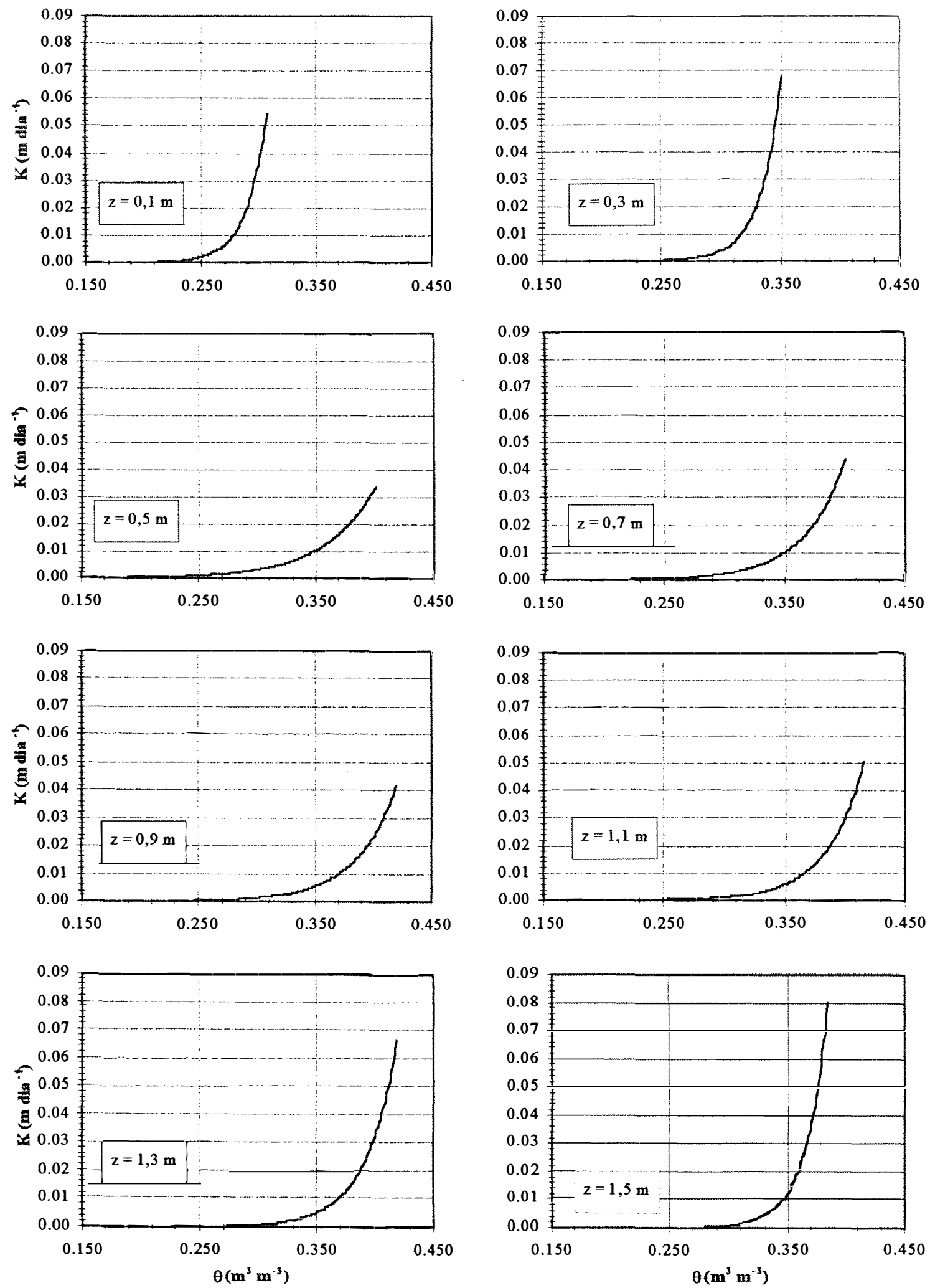

Figura 17 - Condutividade hidráulica (K) versus umidade do solo $(\theta)$. 
Quando apresentadas em conjunto (Figura 18) constata-se comportamento bastante diferenciado entre as curvas de condutividade hidráulica, quanto à condutância, em função das profundidades avaliadas. Este comportamento pode ser dividido em dois grupos sendo o primeiro composto pelas curvas $\mathrm{z}=0,1 \mathrm{~m}, \mathrm{z}=0,3 \mathrm{~m} \mathrm{e}$ $\mathrm{z}=1,5 \mathrm{~m}$ (horizontes $\mathrm{Ap}, \mathrm{BA}$ e $\mathrm{Btx}_{2}$, respectivamente) e um segundo grupo, representado pelas curvas, $\mathrm{z}=0,5 \mathrm{~m}, \mathrm{z}=0,7 \mathrm{~m}$ (horizonte $\mathrm{Bt}$ ) e $\mathrm{z}=0,9 \mathrm{~m}, \mathrm{z}=1,1 \mathrm{~m}$

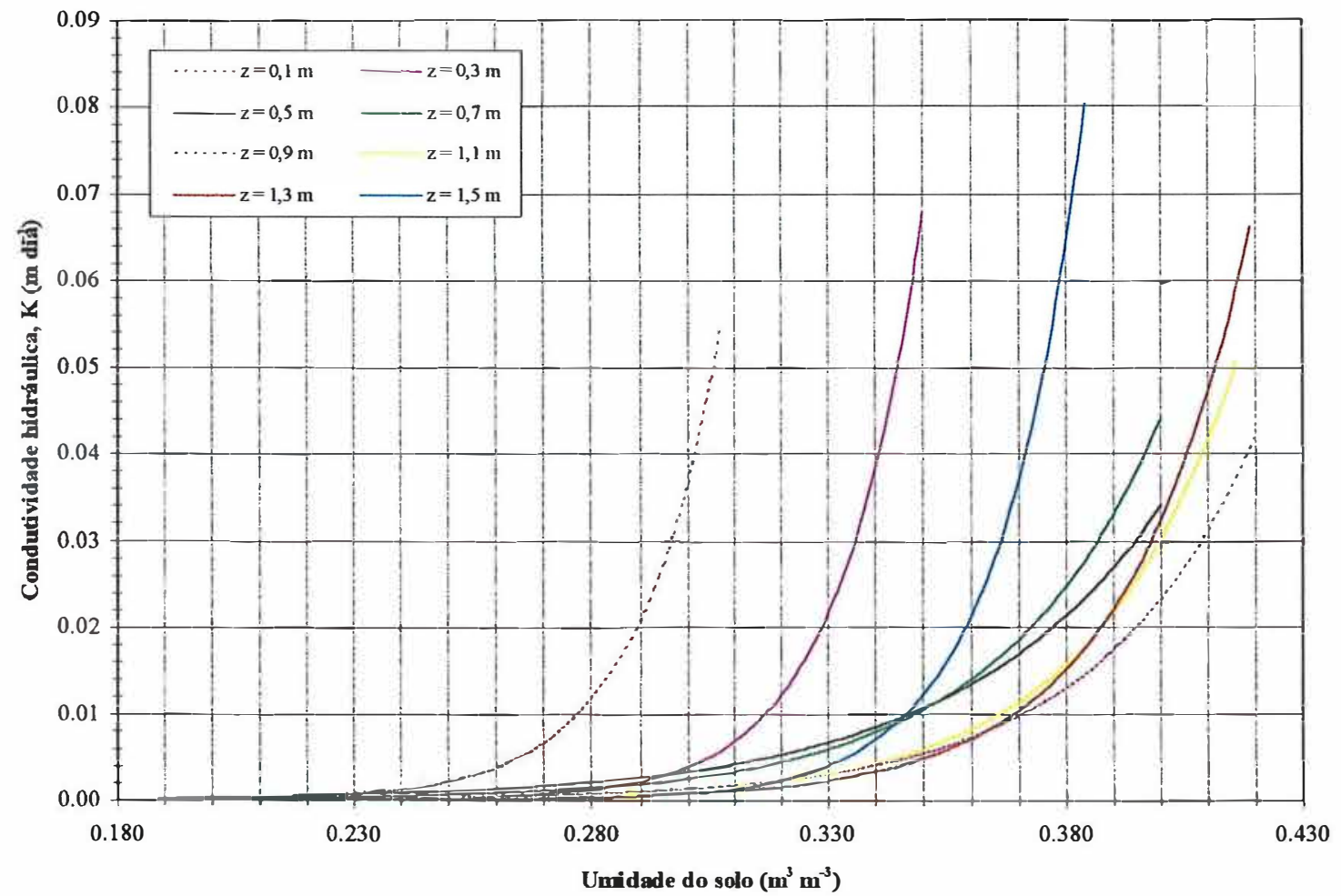

Figura 18 -Condutividade hidráulica $(K)$ versus umidade do solo $(\theta)$, por profundidade.

e $\mathrm{z}=1,3 \mathrm{~m}$ (horizonte $\mathrm{Btx_{1 }}$ ). Em relação ao primeiro grupo é possível observar que apesar da posição diferenciada dos horizontes no perfil, principalmente, em relação ao $\mathrm{Btx}_{2}$, que se situa abaixo de $1,4 \mathrm{~m}$ da profundidade, e das diferenças nas características físicas, principalmente em relação ao BA os horizontes deste grupo se assemelham bastante quanto à condução de água. Quanto ao segundo grupo a homogeneidade observada na condutância dos horizontes $\mathrm{Bt}$ e Btx ${ }_{1}$ deve estar relacionada, em grande parte, à homogeneidade das suas características fisicas (Tabela 3). 
Para a quantificação das diferenças e semelhanças entre e dentro dos grupos, foi utilizado o índice de concordância de Willmott (d) o qual varia entre 0 e 1 onde $\mathrm{o}$ valor 1 indica perfeita similaridade e 0 a inexistência de qualquer concordância entre os modelos (Willmott, 1981). Os valores de condutividade hidráulica, estimados com base nos modelos apresentados na Tabela 7 , foram comparados por profundidade, em diferentes faixas de umidade, de tal forma que fosse possível a comparação de todos os pares. Os resultados obtidos, apresentados na Tabela 8 , evidenciam a baixa sensibilidade do índice nas duas primeiras faixas de umidade, onde a condutividade foi muito baixa (Figura 18), não sendo possível detectar, principalmente na primeira faixa, similaridades entre as profundidades. Na segunda faixa percebe-se, apesar dos baixos indices $\mathrm{d}$, que os valores de condutividade a $0,5 \mathrm{~m}, 0,7 \mathrm{~m}$ e 1,5 $\mathrm{m}$ assemelham-se bastante entre si diferindo, no entanto, das obtidas a $0,9 \mathrm{~m}, 1,1 \mathrm{~m}$ e $1,3 \mathrm{~m}$.

$\mathrm{Na}$ faixa de umidade do solo entre 0,351 e $0,384 \mathrm{~m}^{3} \mathrm{~m}^{-3}$ (Figura 18 , Tabela 8) na qual a sensibilidade do índice de Willmott é ressaltada verifica-se, como regra geral, índices próximos de 1 , ou seja, grande similaridade entre os valores de condutividade hidráulica, para as comparações realizadas entre as profundidade $0,5 \mathrm{~m}$ $0,7 \mathrm{~m}, 0,9 \mathrm{~m}, 1,1 \mathrm{~m}$ e $1,3 \mathrm{~m}$ entre si e, baixo índice d quando estas profundidade foram comparadas com 1,5 m. Este fato permite afirmar que o comportamento hidráulico desta última camada diverge bastante do das demais e ainda possibilita a pressuposição da ocorrência de valores próximos de 1 entre esta e as profundidade 0,1 e $0,3 \mathrm{~m}$, com base no formato das curvas, se os valores de condutividade permitissem a comparação.

Os resultados apresentados na Tabela 8 revelam ainda que o coeficiente de determinação $R^{2}$ o qual indica a percentagem de pontos que pode ser explicada pela interpolatriz, não contribuiu, neste caso para explicar os resultados obtidos, independente das faixas de umidade e de condutividade avaliados. Willmott (1981) apresenta outros exemplos em que fica demonstrada a superioridade do índice $d$ em relação ao $R^{2}$ na comparação de modelos. Quanto ao coeficiente angular da reta de regressão verifica-se que os valores próximos de 1 coincidem com os elevados valores de "d" o que, de certa 
forma, confirma o elevado grau de consistência do índice de Willmott para quantificação das similaridades observadas.

Tabela 8 - Índice de concordância de Wilmott, coeficiente de determinação e equações de regressão linear obtidos na comparação de modelos de condutividade hidráulica, por profundidade.

\begin{tabular}{|c|c|c|c|c|c|}
\hline \multirow{2}{*}{$\begin{array}{l}\text { Faixas de umidade } \\
\qquad \frac{\left(\mathrm{m}^{3} \mathrm{~m}^{-3}\right)}{0,189 \text { a } 0,307}\end{array}$} & \multicolumn{2}{|c|}{$\begin{array}{l}\text { Profundidade } \\
\text { (m) }\end{array}$} & \multirow{2}{*}{$\begin{array}{c}\text { Índice de Willmott } \\
\text { (d) } \\
0,453535\end{array}$} & \multirow{2}{*}{$\frac{\mathrm{R}^{2}}{1,000000}$} & \multirow{2}{*}{$\begin{array}{c}\text { Regressão } \\
y=0,1065 x+2 E-19\end{array}$} \\
\hline & 0,1 & 0,3 & & & \\
\hline & & 0,5 & 0,432556 & 0,883273 & $y=0,0753 x+0,0007$ \\
\hline & & 0,7 & 0,428296 & 0,922663 & $y=0,0604 x+0,0004$ \\
\hline & & 0,9 & 0,414867 & 0,926305 & $y=0,0304 x+0,0002$ \\
\hline & & 1,1 & 0,414800 & 0,943910 & $y=0,0296 x+0,0001$ \\
\hline & & 1,3 & 0,410268 & 0,968724 & $y=0,019 x+6 E-05$ \\
\hline & & 1,5 & 0,411407 & 0,999762 & $y=0,0211 x+4 E-06$ \\
\hline \multirow[t]{6}{*}{0,310 a 0,350} & 0,3 & 0,5 & 0,580222 & 0,971912 & $y=0,1073 x+0,0041$ \\
\hline & & 0,7 & 0,554374 & 0,980431 & $y=0,1194 x+0,0031$ \\
\hline & & 0,9 & 0,336788 & 0,981247 & $y=0,0622 x+0,0015$ \\
\hline & & 1,1 & 0,356612 & 0,985280 & $y=0,0724 x+0,0014$ \\
\hline & & 1,3 & 0,289042 & 0,991173 & $y=0,0634 x+0,0008$ \\
\hline & & 1,5 & 0,524423 & 0,999921 & $y=0,1797 x+0,0002$ \\
\hline \multirow[t]{15}{*}{0,351 a 0,384} & 0,5 & 0,7 & 0,996586 & 0,999445 & $y=1,3541 x-0,0042$ \\
\hline & & 0,9 & 0,928627 & 0,999321 & $y=0,7198 x-0,0024$ \\
\hline & & 1,1 & 0,964444 & 0,998456 & $y=0,9364 x-0,0043$ \\
\hline & & 1,3 & 0,947549 & 0,996097 & $y=0,9963 x-0,0063$ \\
\hline & & 1,5 & 0,799535 & 0,981948 & $y=5,244 x-0,0491$ \\
\hline & 0,7 & 0,9 & 0,901294 & 0,999994 & $y=0,5316 x-0,0002$ \\
\hline & & 1,1 & 0,944722 & 0,999752 & $y=0,6918 x-0,0014$ \\
\hline & & 1,3 & 0,925857 & 0,998482 & $y=0,7364 x-0,0032$ \\
\hline & & 1,5 & 0,841106 & 0,987666 & $y=3,8829 x-0,0329$ \\
\hline & 0,9 & 1,1 & 0,992423 & 0,999824 & $y=1,3014 x-0,0012$ \\
\hline & & 1,3 & 0,996212 & 0,998671 & $y=1,3855 x-0,0029$ \\
\hline & & 1,5 & 0,602494 & 0,988211 & $y=7,3062 x-0,0316$ \\
\hline & 1,1 & 1,3 & 0,998063 & 0,999461 & $y=1,0649 x-0,0017$ \\
\hline & & 1,5 & 0,670556 & 0,990894 & $y=5,621 x-0,0251$ \\
\hline & 1,3 & 1,5 & 0,645444 & 0,994769 & $y=5,2874 x-0,0164$ \\
\hline
\end{tabular}

O comportamento similar quanto à condução de água, entre os horizontes Ap e BA com o $\mathrm{Btx}_{2}$, aparentemente contraditório, pode estar relacionado aos altos teores de areia do Ap, principalmente, das frações mais grossas (Tabela 3), elevada coesão do $\mathrm{BA}$ e à estrutura maciça do horizonte $\mathrm{Btx}_{2}$ (ver descrição morfológica no item 3.3.1) cujas características comumente promovem queda acentuada da 
condutividade hidráulica com pequena redução na umidade do solo. O fato da distribuição do tamanho das partículas e estrutura do solo serem os principais fatores determinantes da geometria dos poros e, como consequência, da tortuosidade, permite atribuir, a estes fatores as similaridades observadas entre estes horizontes. Nesse contexto, pode-se supor que, enquanto a baixa condutividade do BA e do Btx $x_{2}$ é função do aumento da tortuosidade proporcionada pela sua condição estrutural, no horizonte Ap a baixa condutividade deve estar também associada à tortuosidade porém relacionada às suas características granulométricas. Este fenômeno pode ser melhor visualizado na Figura 19 onde a condutividade é expressa em termos de condutividade hidráulica relativa $(\mathrm{Kr})$. Ao se fixar uma mesma taxa de redução na umidade, de por exemplo 0,02 $\mathrm{m}^{3} \mathrm{~m}^{-3}$, a partir do tempo inicial de redistribuição $0,307,0,350,0,400$ e 0,410 e $0,384 \mathrm{~m}^{3}$ $\mathrm{m}^{-3}$ para os horizontes Ap $(\mathrm{z}=0,1 \mathrm{~m}), \mathrm{BA}(\mathrm{z}=0,3 \mathrm{~m}), \mathrm{Bt}(\mathrm{z}=0,5$ e $0,7 \mathrm{~m}), \mathrm{Btx}_{1}$ $(\mathrm{z}=0,9,1,1$ e $1,3 \mathrm{~m})$ e $\mathrm{Btx}_{2}(\mathrm{z}=1,5 \mathrm{~m})$, respectivamente (Tabela 7$)$, verifica-se uma queda em torno de $70 \%$ na condutividade hidráulica relativa nos horizontes Ap, BA,

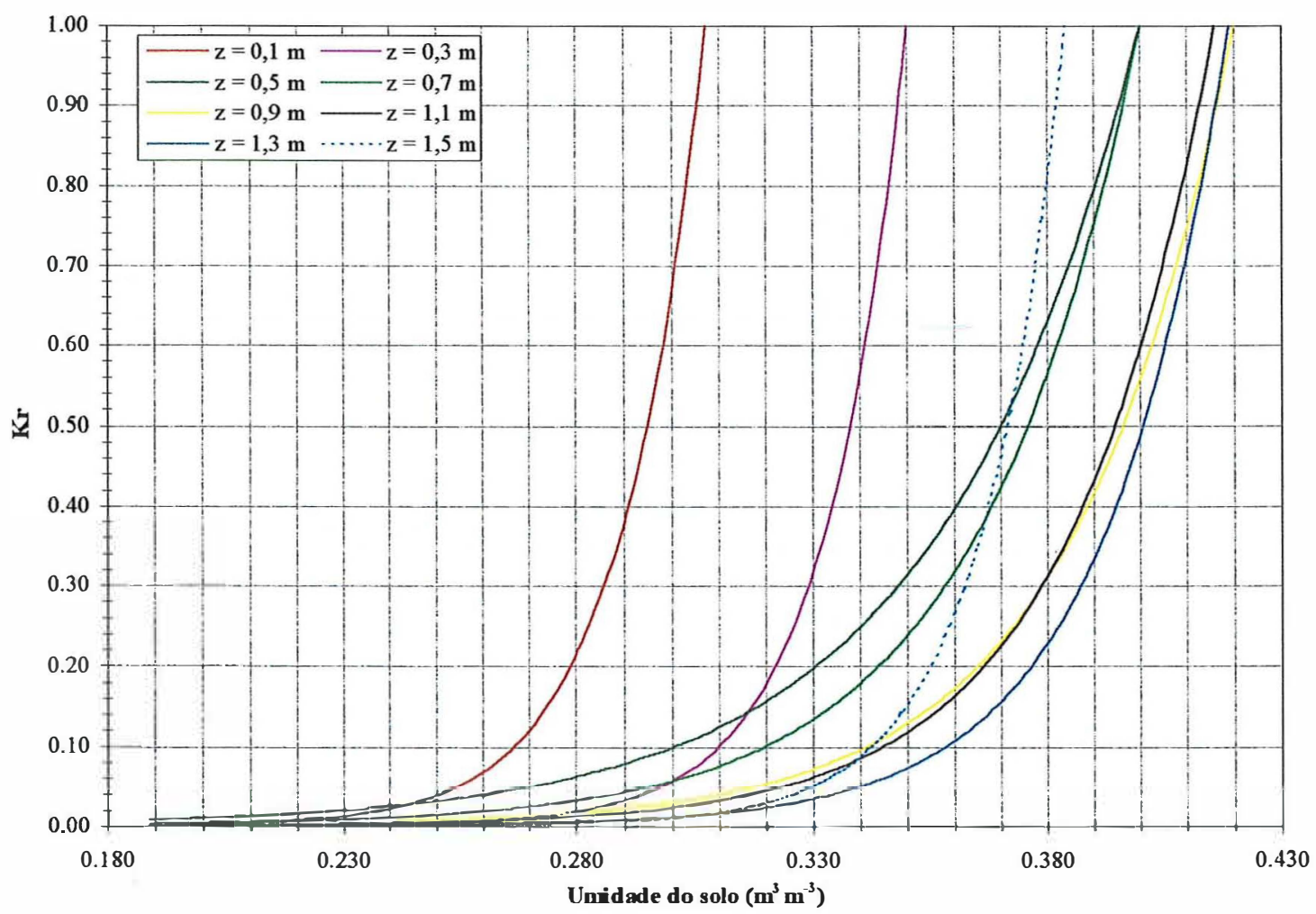

Figura 19 - Condutividade hidráulica relativa (Kr) versus umidade do solo. 
e Btx 2 e de $40 \%$ nos horizontes Bt e Btx 1 . Estes resultados expressam o elevado grau de similaridade entre os horizontes $\mathrm{Ap}, \mathrm{BA}$ e $\mathrm{Btx}_{2}$ e entre os horizontes $\mathrm{Bt}$ e Btx confirmando a pressuposição feita, com base na Figura 18, da existência no solo de dois grupos distintos quanto às características hidráulicas.

Com base nesses resultados é possível pressupor que as variações na condução de água no perfil poderão produzir uma zona de armazenagem entre os horizontes BA e $\mathrm{Btx}_{2}$, com aproximadamente $1 \mathrm{~m}$ de espessura, a ser formada, provavelmente, nos primeiros meses após o período chuvoso onde deverão ocorrer os principais fenômenos relacionados ao movimento e redistribuição de água durante o período que antecede o ápice da estação seca. Callot et al. (1982) observaram que os estados de umidade em um perfil de solo são dependentes não só dos fluxos externos, como também, das relações que existem entre as camadas. Em solos descontínuos, caso em que se enquadra a classe de solo estudada, as camadas que promovem a descontinuidade (horizontes BA e Btx 2 ) bloqueiam tanto a drenagem profunda quanto a ascenção capilar. Este bloqueio está em geral relacionado à condutividade hidráulica das diferentes camadas de solo. Hillel (1970) ressalta que a existência de uma camada arenosa em um perfil de textura fina em lugar de intensificar a drenagem pode, na verdade, restringir o movimento da água até que esta se acumule o suficiente para saturar os poros grandes. Quando os poros são grandes, caso do horizonte $\mathrm{Ap}$, são rapidamente esvaziados com pequena redução no teor de água e tornam-se, rapidamente, pouco condutivos. Poros pequenos, por outro lado, permanecem cheios e condutivos para um mesmo valor de queda de umidade, reduzindo mais lentamente a condutividade hidráulica, sendo este o comportamento observado nos horizontes Bt e Btx 1 . Nos horizontes BA e Btx 2 apesar da grande proporção de poros pequenos, a elevada tortuosidade proporcionada pela alta densidade do solo e pela estrutura maciça atua, provavelmente, como o principal fator restritivo à condução de água. 


\subsubsection{Balanço hídrico}

$\mathrm{Na}$ Tabela 9 estão apresentados os resultados do balanço hídrico realizado para a camada de solo de 0 a $1,1 \mathrm{~m}$ de profundidade, para cada porta-enxerto, em dez períodos ao longo de um ano de monitoramento do potencial mátrico da água no solo (dezembro de 1995 a novembro de 1996). Com base na distribuição pluvial foi possível dividir o ano agrícola em dois períodos climáticos distintos: um período com baixo volume total de chuvas (entre 01/12/95 a 15/04/96 e 01/10/96 a 30/11/96) e um período chuvoso (entre 16/04/96 a 30/09/96).

A importância do balanço hídrico como uma ferramenta para avaliar a intensidade das saídas e entradas de água no solo e, por conseguinte, para definição dos períodos mais prováveis de déficits hídricos para a cultura está relacionada não só ao conhecimento dos fatores que o compõem (evapotranspiração, precipitação, drenagem interna ou ascenção capilar), como também, ao conhecimento das características da planta, principalmente da sua fenologia, que representa o ponto de partida para a interpretação coerente dos resultados do balanço.

As plantas cítricas mantêm-se com folhas durante todo o ciclo vegetativo o que as fazem transpirar durante todo o ano. Ortolani et al. (1991) citam intervalo de evapotranspiração entre 600 e 1300 anuais cujas taxas, mais intensas nas fases de intensa vegetação floral, são variáveis em função do manejo aplicado na cultura, da variedade utilizada e da combinação copa/porta-enxerto. Em geral, os períodos de maior demanda hídrica dos citros são a fase de brotação, emissão dos botões florais, frutificação e início de desenvolvimento dos frutos e, os de menor demanda, vão da maturação à colheita seguidos da fase de semi-dormência que sobrevem à colheita (Vieira, 1991). Nas regiões tropicais (caso dos tabuleiros costeiros) os citros podem florescer várias vezes ao ano, após períodos prolongados de estiagem. Na variedade Pêra, as floradas extemporâneas são uma de suas principais características a qual também se manifesta, porém com menor intensidade, nas regiões subtropicais. Entre as variedades comerciais cultivadas no Estado de São Paulo, citadas por Figueiredo (1991), a laranjeira 
Tabela 9 - Balanço hídrico dos porta-enxertos estudados (camada de solo; 0 a 1,1 m).

\begin{tabular}{|c|c|c|c|c|c|c|c|c|}
\hline \multirow[t]{2}{*}{ Porta-enxertos } & \multirow[t]{2}{*}{ Periodo do Balanço } & \multirow[t]{2}{*}{$N^{0}$ de dias } & $\mathbf{P}$ & D & Variaçāo armaz & ET (periodo) & \multirow{2}{*}{$\begin{array}{l}\text { ET (dkária) } \\
\left(\mathrm{mm} \text { dia }^{-1}\right)\end{array}$} & \multirow{2}{*}{$\begin{array}{c}\text { EUA } \\
\left(\mathrm{kg} \mathrm{m}^{-3}\right) \\
\end{array}$} \\
\hline & & & \multicolumn{4}{|c|}{$(\mathbf{m m})$} & & \\
\hline \multirow[t]{11}{*}{ Limão V. Palemno } & $01 / 12 / 25 / 03$ & 116 & 137,7 & $-42,7$ & $-19,5$ & $-114,5$ & $-1,0$ & \\
\hline & $26 / 03 / 15 / 04$ & 21 & 112,4 & $-4,1$ & 7,6 & $-100,7$ & $-4,8$ & \\
\hline & $16 / 04 / 15 / 05$ & 30 & 159,4 & $-45,7$ & 0,1 & $-113,6$ & $-3,8$ & \\
\hline & $16 / 05 / 10 / 06$ & 26 & 231,6 & $-92,8$ & 91,0 & $-47,8$ & $-1,8$ & \\
\hline & $11 / 06 / 30 / 06$ & 20 & 115,8 & $-136,3$ & $-67,5$ & $-47,0$ & $-2,4$ & \\
\hline & $01 / 07 / 31 / 07$ & 31 & 82,2 & $-48,7$ & $-21,6$ & $-55,1$ & $-1,8$ & \\
\hline & $01 / 08 / 31 / 08$ & 31 & 184,6 & $-114,8$ & 20,0 & $-49,8$ & $-1,6$ & \\
\hline & $01 / 09 / 30 / 09$ & 30 & 119,3 & $-53,7$ & 22,9 & $-42,7$ & $-1,4$ & \\
\hline & $01 / 10 / 31 / 10$ & 31 & 41,6 & $-32,3$ & $-73,5$ & $-82,7$ & $-2,7$ & \\
\hline & $01 / 11 / 30 / 11$ & 30 & 131,4 & 38,0 & $-11,2$ & $-180,7$ & $-6,0$ & \\
\hline & Total & 366 & 1316,0 & $-533,1$ & $.51,8$ & $-834,7$ & & 6,4 \\
\hline \multirow[t]{11}{*}{ Limào V.Catâria } & $01 / 12 / 25 / 03$ & 116 & 137,7 & 1,9 & $-62,6$ & $-202,2$ & $-1,7$ & \\
\hline & $26 / 03 / 15 / 04$ & 21 & 112,4 & 1,4 & 64,6 & $-49,3$ & $-2,3$ & \\
\hline & $16 / 04 / 15 / 05$ & 30 & 159,4 & $-71,7$ & $-7,8$ & $-95,5$ & $-3,2$ & \\
\hline & $16 / 05 / 10 / 06$ & 26 & 231,6 & $-118,7$ & 100,6 & $-12,3$ & $-0,5$ & \\
\hline & $11 / 06 / 30 / 06$ & 20 & 115,8 & $-135,7$ & $-64,3$ & $-44,4$ & $-2,2$ & \\
\hline & $01 / 07 / 31 / 07$ & 31 & 82,2 & $-50,2$ & $-20,1$ & $-52,1$ & $-1,7$ & \\
\hline & $01 / 08 / 31 / 08$ & 31 & 184,6 & $-125,5$ & 9,0 & $.50,1$ & $-1,6$ & \\
\hline & $01 / 09 / 30 / 09$ & 30 & 119,3 & $-56,7$ & $-13,6$ & $.76,2$ & $-2,5$ & \\
\hline & $01 / 10 / 31 / 10$ & 31 & 41,6 & $-9,6$ & $-63,7$ & $-95,8$ & $-3,1$ & \\
\hline & $01 / 11 / 30 / 11$ & 30 & 131,4 & 16,5 & $-4,3$ & $-152,2$ & $-5,1$ & \\
\hline & Total & 366 & 1316,0 & $-548,2$ & $-62,2$ & $-830,0$ & & 4,4 \\
\hline \multirow[t]{11}{*}{ Limão Cravo } & $01 / 12 / 25 / 03$ & 116 & 137,7 & $-71,6$ & $-65,7$ & $.131,9$ & $-1,1$ & \\
\hline & $26 / 03 / 15 / 04$ & 21 & 112,4 & 1,1 & 56,3 & $-57,2$ & $-2,7$ & \\
\hline & $16 / 04 / 15 / 05$ & 30 & 159,4 & $-66,9$ & 3,8 & $-88,8$ & $-3,0$ & \\
\hline & $16 / 05 / 10 / 06$ & 26 & 231,6 & $-103,5$ & 83,4 & $.44,8$ & $-1,7$ & \\
\hline & $11 / 06 / 30 / 06$ & 20 & 115,8 & $-102,2$ & $-61,4$ & $-75,0$ & $-3,8$ & \\
\hline & $01 / 07 / 31 / 07$ & 31 & 82,2 & $-48,6$ & $-12,1$ & $-45,8$ & $-1,5$ & \\
\hline & $01 / 08 / 31 / 08$ & 31 & 184,6 & $-119,4$ & 12,4 & $-52,8$ & $-1,7$ & \\
\hline & $01 / 09 / 30 / 09$ & 30 & 119,3 & $-71,0$ & $-4,0$ & $-52,3$ & $-1,7$ & \\
\hline & $01 / 10 / 31 / 10$ & 31 & 41,6 & $-36,9$ & $-68,2$ & $.72,8$ & $-2,3$ & \\
\hline & $01 / 11 / 30 / 11$ & 30 & 131,4 & $-3,6$ & .7 .9 & $-135,6$ & $.4,5$ & \\
\hline & Total & 366 & 1316.0 & $-622,5$ & $-63,5$ & $-757,0$ & & 6,0 \\
\hline \multirow[t]{11}{*}{ Limão R. da Flórida } & $01 / 12 / 25 / 03$ & 116 & 137,7 & $-40,2$ & $-67,1$ & $-164,6$ & $-1,4$ & \\
\hline & $26 / 03 / 15 / 04$ & 21 & 112,4 & 0,5 & 37,4 & $-75,6$ & $-3,6$ & \\
\hline & $16 / 04 / 15 / 05$ & 30 & 159,4 & $-52,3$ & 5,5 & $-101,6$ & $-3,4$ & \\
\hline & $16 / 05 / 10 / 06$ & 26 & 231,6 & $-47,4$ & 93,8 & $-90,4$ & $-3,5$ & \\
\hline & $11 / 06 / 30 / 06$ & 20 & 115,8 & $-128,4$ & $-60,7$ & $-48,0$ & $-2,4$ & \\
\hline & $01 / 07 / 31 / 07$ & 31 & 82,2 & $-42,6$ & $-21,3$ & $-60,9$ & $-2,0$ & \\
\hline & $01 / 08 / 31 / 08$ & 31 & 184,6 & $-107,7$ & 21,8 & $-55,1$ & $-1,8$ & \\
\hline & 01/09/30/09 & 30 & 119,3 & $-68,4$ & $-7,3$ & $-58,2$ & $-1,9$ & \\
\hline & $01 / 10 / 31 / 10$ & 31 & 41,6 & $-26,3$ & $-57,9$ & $-73,2$ & $-2,4$ & \\
\hline & $01 / 11 / 30 / 11$ & 30 & 131,4 & 20,5 & $-8,0$ & $-159,9$ & $-5,3$ & \\
\hline & Total & 366 & 1316,0 & $-492,3$ & $.63,9$ & $-887,6$ & & 5,6 \\
\hline \multirow[t]{11}{*}{ Tangerina Cleópatra } & $01 / 12 / 25 / 03$ & 116 & 137,7 & $-46,2$ & $-50,7$ & $-142,2$ & $-1,2$ & \\
\hline & $26 / 03 / 15 / 04$ & 21 & 112,4 & 1,9 & 30,5 & $.83,8$ & $-4,0$ & \\
\hline & $16 / 04 / 15 / 05$ & 30 & 159,4 & $-1,9$ & $-0,5$ & $-158,0$ & $-5,3$ & \\
\hline & $16 / 05 / 10 / 06$ & 26 & 231,6 & $-57,3$ & 119,9 & $-54,4$ & $-2,1$ & \\
\hline & $11 / 06 / 30 / 06$ & 20 & 115,8 & $-178,1$ & $-77,9$ & $-15,6$ & $-0,8$ & \\
\hline & $01 / 07 / 31 / 07$ & 31 & 82,2 & $-46,9$ & $-21,8$ & $-57,2$ & $-1,8$ & \\
\hline & $01 / 08 / 31 / 08$ & 31 & 184,6 & $-112,2$ & 13,9 & $-58,5$ & $-1,9$ & \\
\hline & $01 / 09 / 30 / 09$ & 30 & 119,3 & $-37,9$ & $-25,4$ & $-106,8$ & $-3,6$ & \\
\hline & $01 / 10 / 31 / 10$ & 31 & 41,6 & 12,3 & $-35,6$ & $.89,5$ & $-2,9$ & \\
\hline & $01 / 11 / 30 / 11$ & 30 & 131,4 & 44,0 & $-3,3$ & $-178,8$ & $-6,0$ & \\
\hline & Total & 366 & 1316,0 & $-422,1$ & $.51,0$ & $.944,9$ & & 3,6 \\
\hline
\end{tabular}


Pêra é a única cuja época de colheita é extendida por todo o ano porém, com pico de produção entre junho e novembro.

$\mathrm{Na}$ Tabela 9 verifica-se que as taxas anuais de evapotranspiração se encontram dentro da faixa citada por Ortolani et al. (1991). No entanto, em virtude das diferenças existentes entre o regime climático das regiões subtropicais e o da região Nordeste, a comparação do total evapotranspirado entre porta-enxertos, independente da faixa apresentada, dará uma indicação mais precisa das suas diferenças. Nessa Tabela é possivel observar que no extremo inferior, com $757 \mathrm{~mm}$ de água evapotranspirada encontra-se o Limão Cravo e, no limite superior, a Tangerina Cleópatra com $945 \mathrm{~mm}$ o que representa uma diferença em torno de $200 \mathrm{~mm}$ anuais. Quanto aos outros materiais os Limões Volcamerianos apresentam taxas similares entre si e próximas à do Limão Cravo, enquanto que, a taxa do limão Rugoso está mais próxima da Tangerina Cleópatra. Com base nestes dados é possível inferir que estes dois últimos porta-enxertos sofrem maior nível de estresse nos períodos de déficit ou de maior demanda hídrica. Estes resultados combinam com as observações de Mechlia \& Carroll (1989) os quais estimaram, por modelagem, o intervalo de evapotranspiração entre 4 e $8 \mathrm{~mm} \mathrm{dia}^{-1}$ como limitante à produção de citros. Na Tabela 9 verifica-se que os valores máximos de evapotranspiração diária, nos períodos de maior demanda hídrica, são observados na Tangerina Cleópatra e os menores valores no Limão Cravo os quais estão abaixo ou muito próximos do limite mínimo estabelecido por estes autores. Vale lembrar que as comparações feitas com base na evapotranspiração diária são mais representativas pois eliminam o efeito proveniente do intervalo variável de tempo do balanço.

As informações existentes para as regiões produtoras de citros do Nordeste indicam como período de maior demanda de água os meses de agosto a novembro quando as plantas iniciam a emissão dos botões florais, a frutificação e o desenvolvimento dos frutos e, como período de menor demanda, os meses de abril a setembro quando ocorre o início da maturação e colheita dos frutos. Os resultados apresentados na Figura 20, onde os porta-enxertos estão agrupados por período, 
demonstram, no entanto, comportamento diferenciado para a unidade geoambiental onde este estudo foi realizado. Independente do porta-enxerto, as maiores taxas de evapotranspiração ocorreram entre 26/03 e 15/05 (final do período seco e início do chuvoso), fase que coincide com o início da maturação e da colheita dos frutos, e durante o mês de novembro, período onde os porta-enxertos apresentam as maiores taxas de evapotranspiração e que coincide com o início da brotação e frutificação. Estes resultados demonstram portanto que, nas condições deste estudo, a demanda hídrica entre os períodos citados, não é tão diferente nem tão extensa como normalmente referido para as regiões subtropicais ou como observado em outras regiões produtoras de citros do Nordeste.

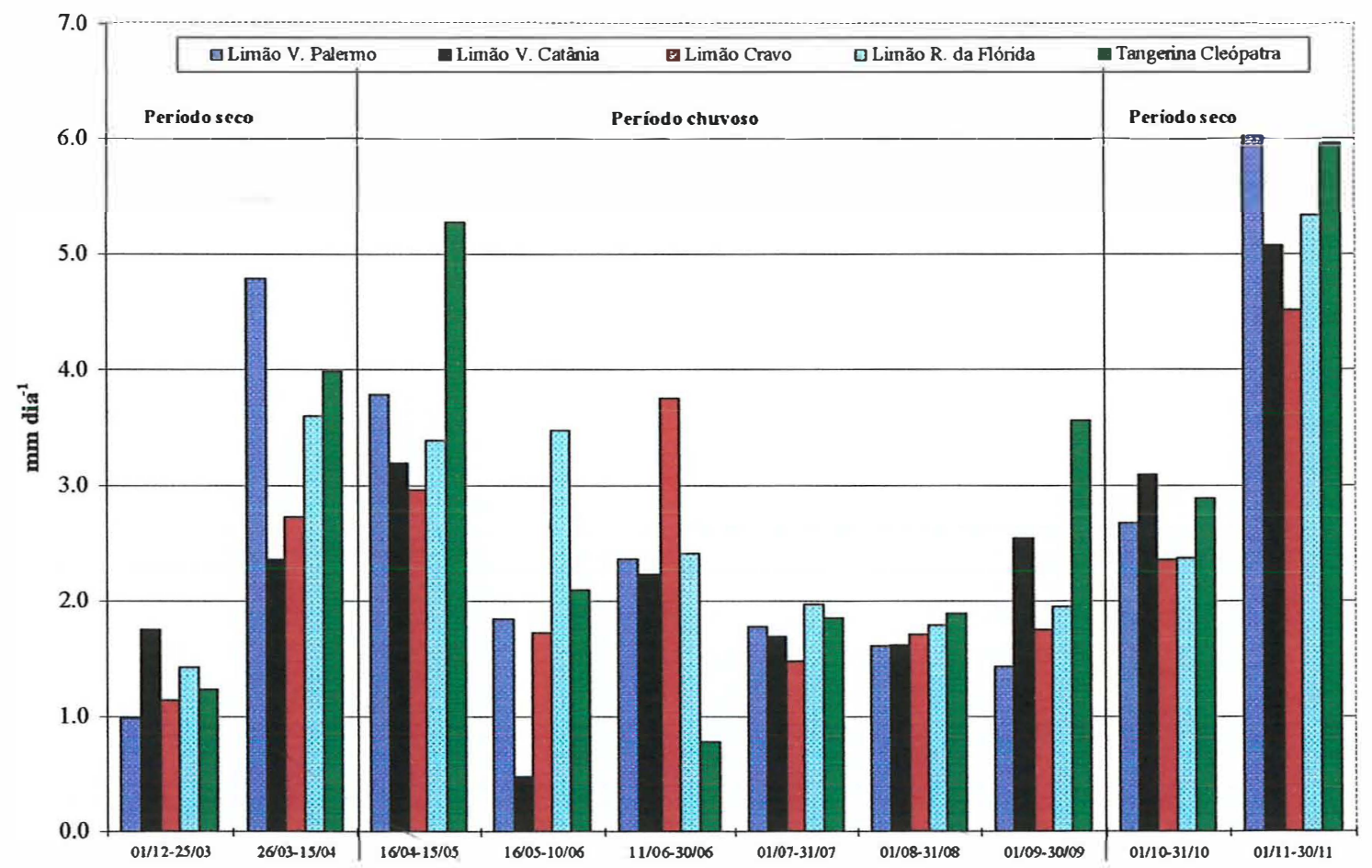

Figura 20 - Evapotranspiração diária, por porta-enxerto, para cada peródo do balanço hidrico.

Com base na Figura 20 é possível ainda observar que os períodos considerados como de alta demanda hídrica são seguidos por períodos de demanda intermediária (entre 16/05 a 30/09) e de baixa demanda (entre 01/12 a 25/03) o qual 
coincide com os meses mais secos do ano onde a atividade da planta é muito reduzida. Quanto à duração dos períodos com taxas elevadas de evapotranspiração, verifica-se nessa Figura que o Limão Rugoso da Flórida apresenta o intervalo mais longo na fase de maturação dos frutos (evapotranspiração alta e constante entre 26/03 e 10/06) considerada, no entanto, menos crítica e que a Tangerina Cleópatra apresenta o maior intervalo com elevadas taxas de evapotranspiração na fase mais crítica ao desenvolvimento da planta ou seja, no início da emissão dos botões florais e de formação dos frutos (entre 01/09 e 30/11/96).

Nas Figuras 21, 22, 23, 24 e 25 onde os componentes do balanço (precipitação, evapotranspiração, drenagem ou ascenção capilar) são visualizados em conjunto é possivel avaliar o comportamento da água no solo (drenagem e ascenção capilar) e na planta (evapotranspiração) em função da distribuição das chuvas ao longo de um ano de observação. O balanço foi realizado em dez períodos, com intervalo variável de tempo, tendo o primeiro período duração de 116 dias e os demais entre 20 e 31 dias (Tabela 9). Esta subdivisão teve como objetivo priorizar a estação chuvosa e os periodos imediatamente anterior e posterior, considerados de grande importância na fenologia dos citros. Vale lembrar, portanto, que na análise visual dos gráficos que serão apresentados a seguir o primeiro período deve ser excluído da comparação com os demais devido à grande dessemelhança quanto aos intervalo de tempo. 


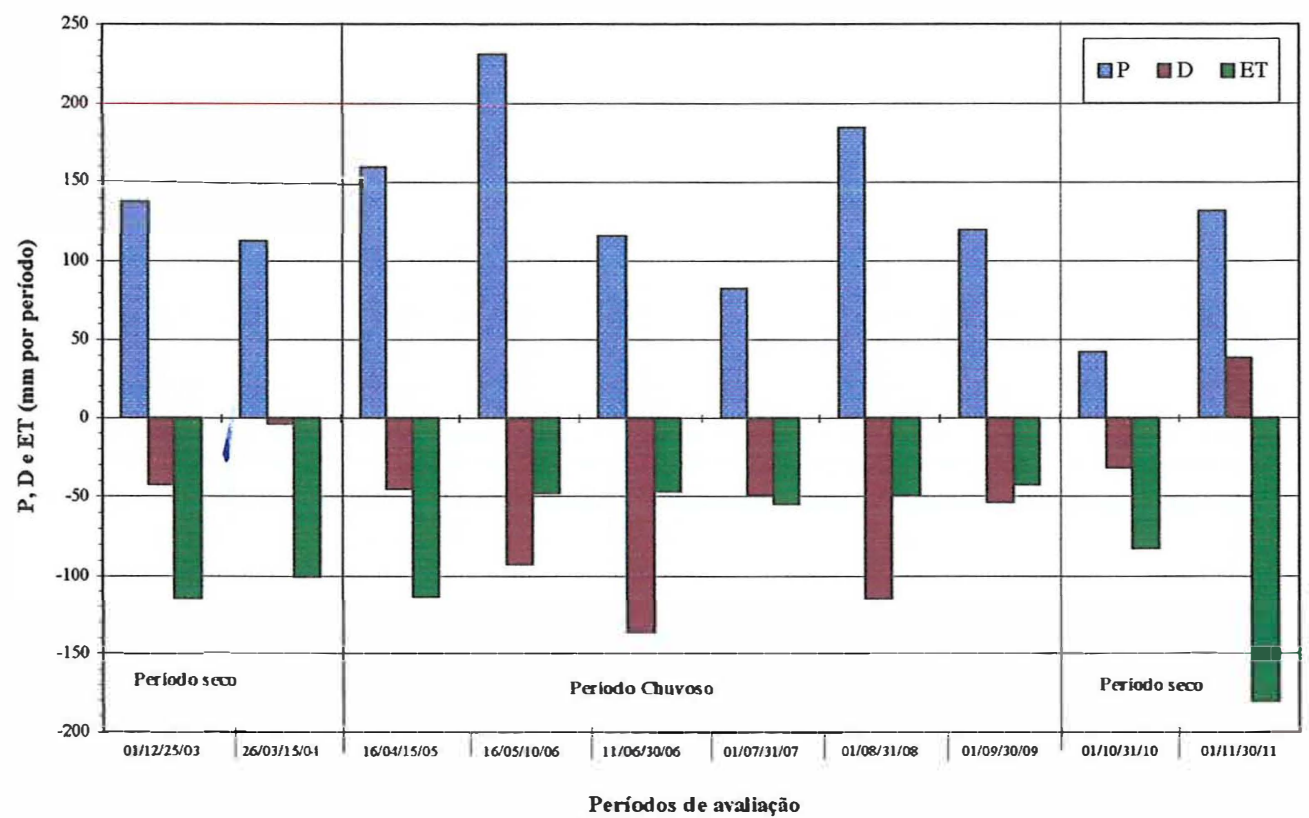

Figura 21 - Balanço hídrico do Limão Volcameriano Palermo.

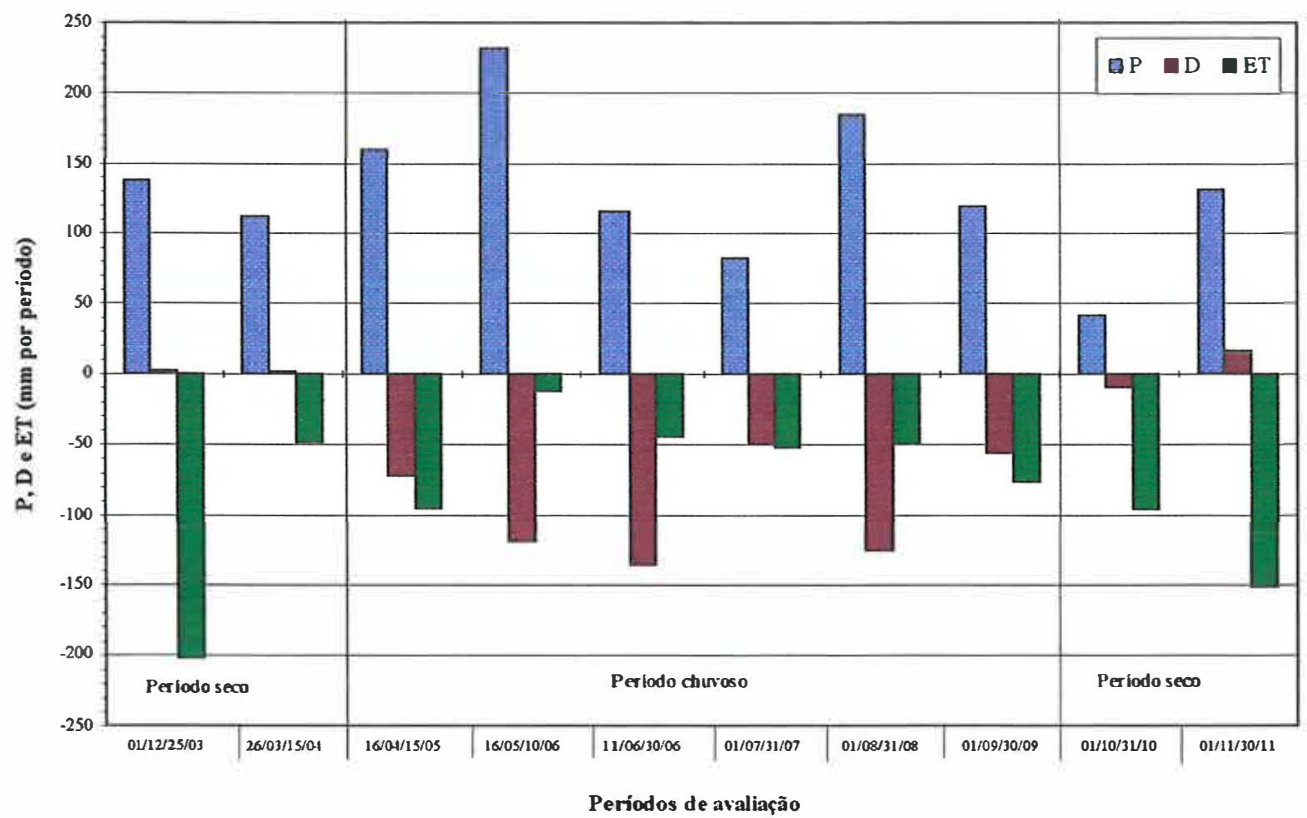

Figura 22 - Balanço hídrico do Limão Volcameriano Catânia 


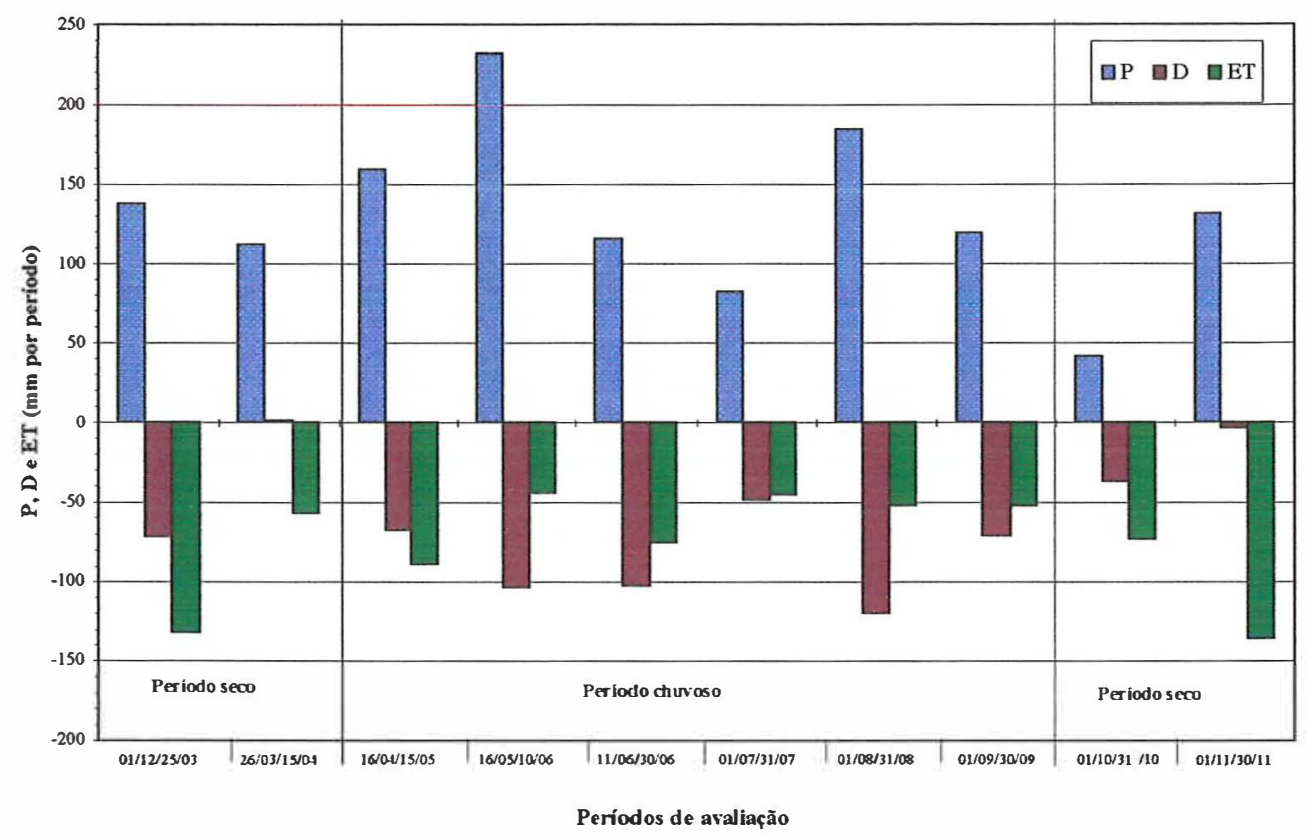

Figura 23 - Balanço hidrico do Limão Cravo

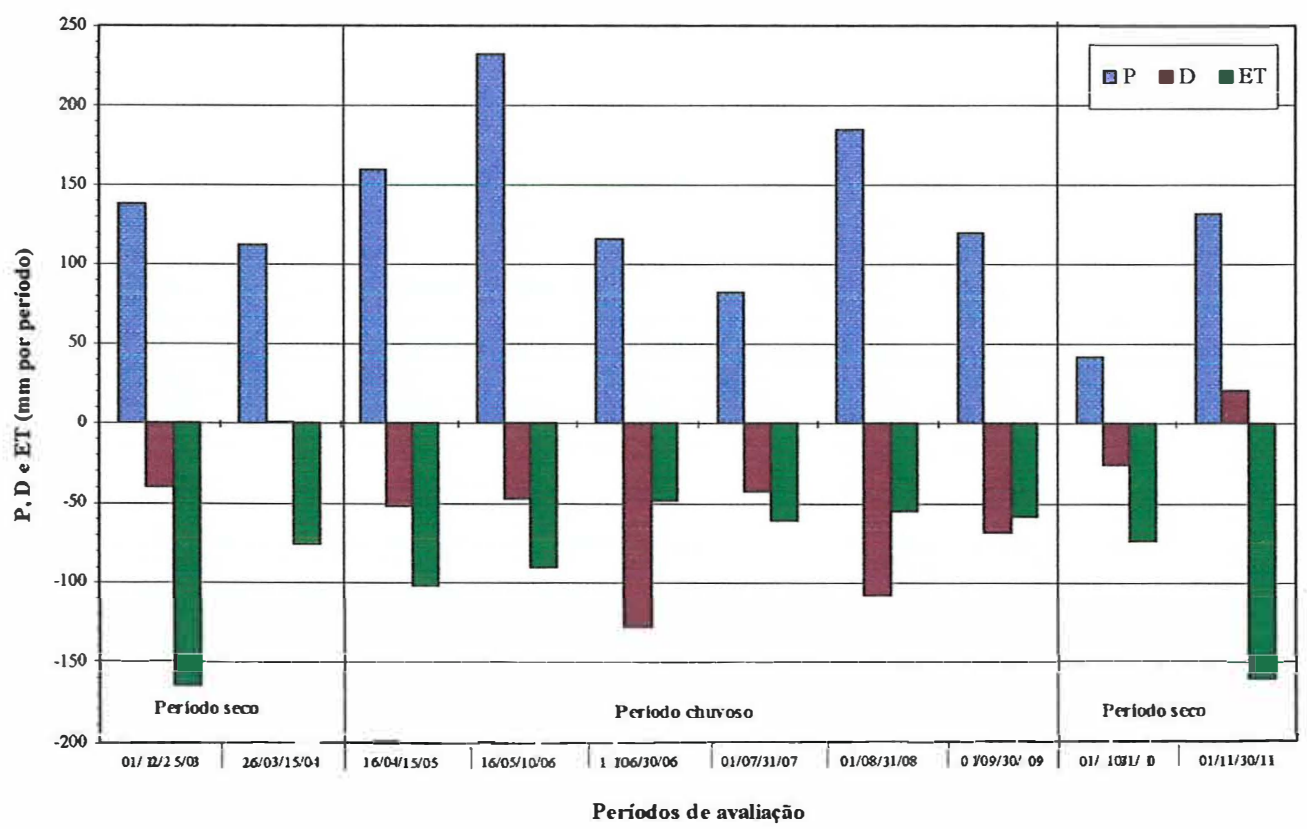

Figura 24 - Balanço hídrico do Limão Rugoso da Flórida 


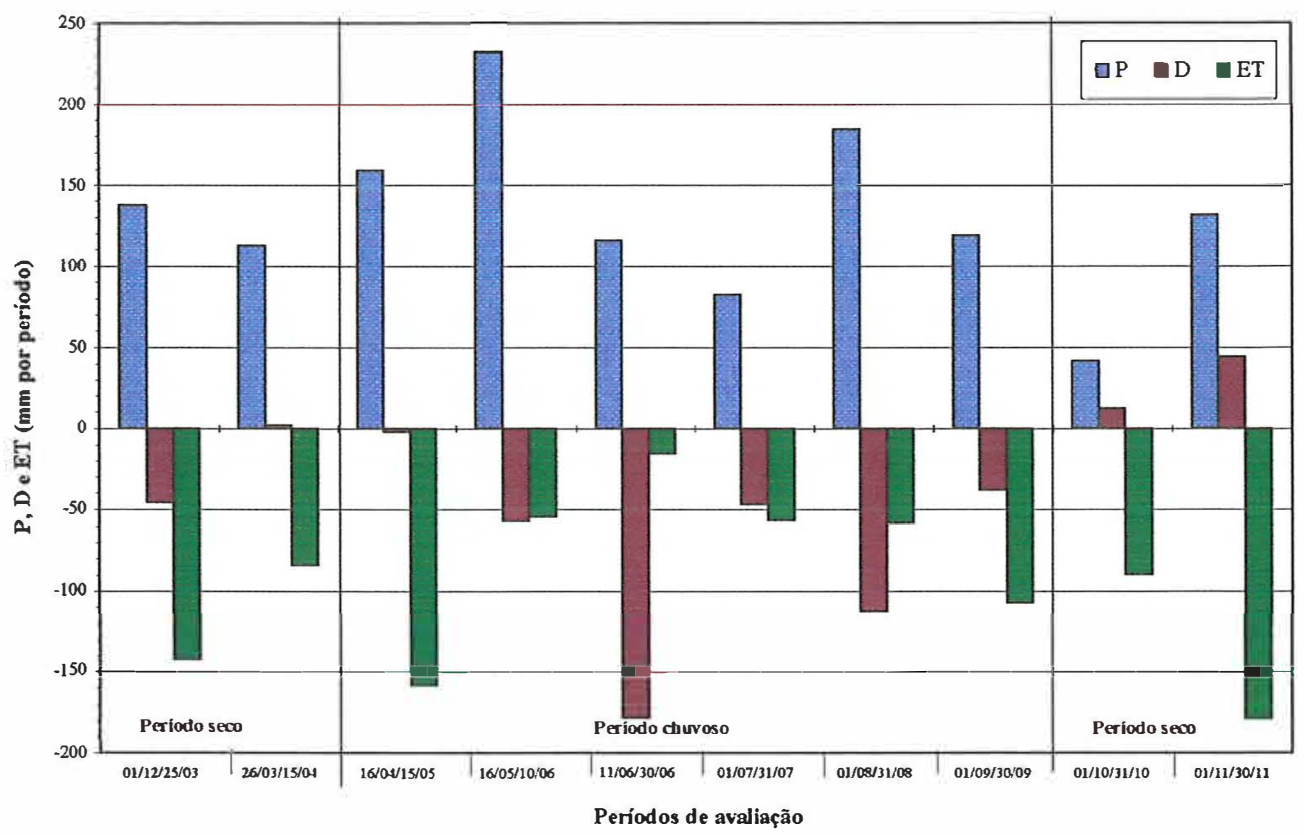

Figura 25 - Balanço hídrico da Tangerina Cleópatra

O primeiro fato a destacar nas Figuras $21,22,23,24$ e 25, comum a todos os porta-enxertos e relacionados à drenagem, diz respeito à existência de ascenção capilar no período que antecede a estação chuvosa à exceção do Limão Volcameriano Palermo que apresenta, no entanto, taxa de drenagem muito baixa. Esta fase coincide com o início da maturação dos frutos quando a demanda hídrica da planta é alta e as reservas de água no solo baixas. No período imediatamente posterior, correspondente ao início da estação chuvosa (16/04 a 15/06) a drenagem interna se faz presente apesar da elevada taxa de evapotranspiração de todos os materiais face à constância e ao volume das chuvas. Vale ressaltar, no entanto, que neste período a evapotranspiração da Tangerina Cleópatra já é muito elevada em relação aos outros porta-enxertos, restringindo ao mínimo a taxa de drenagem.

Um segundo fato a destacar pode ser observado na fase pós período chuvoso, correspondente aos meses de outubro e novembro e, nos quais, as plantas se encontram em estágio de máxima atividade (fase de formação dos botões florais e início 
da frutificação). É possível verificar em todos os porta-enxertos (Figuras 21, 22, 23, 24 e 25), forte redução das taxas de drenagem no mês de outubro e processo de ascenção capilar no mês de novembro. Nesta fase, diferentemente da que antecedeu ao período chuvoso, a ascenção capilar é, provavelmente, originada das elevadas taxas de evapotranspiração na medida em que não houve redução sensivel da precipitação pluvial nestes meses. Mais uma vez, vale ressaltar o comportamento da Tangerina Cleópatra cujas taxas de evapotranspiração, mantidas altas desde o final do período chuvoso (mês de setembro), forçaram o processo de ascenção capilar já no mês de outubro.

Na última coluna da Tabela 9 são apresentados os índices que permitem comparar os porta-enxertos quanto à eficiência de absorção de água, índice EUA, correspondente a quilos de frutos produzidos por porta-enxerto para cada metro cúbico de água absorvido. O baixo valor do índice EUA para Tangerina Cleópatra confirma o resultado do balanço hídrico que atribue a este porta-enxerto as maiores taxas de evapotranspiração nos períodos de maior demanda hídrica da planta. Quanto aos outros materiais observa-se a existência de um grupo relativamente homogêneo quanto à eficiência de uso da água do solo composto pelo Limão Cravo, Limão Volcameriano Palermo e Limão Rugoso da Flórida. Convém ressaltar, no entanto, que o Limão Cravo, por apresentar as menores taxas de evapotranspiração entre os três materiais deve reagir de forma mais positiva, quanto ao uso da água no solo, em anos com déficits pluviométricos acentuados. A baixa eficiência de uso da água observada no Limão Volcameriano Catânia, pode estar relacionada a outros problemas com reflexo direto sobre o rendimento das plantas. Com base em levantamento feito pela FAO (Doorenbos \& Kassan, 1979) os índices relacionados à eficiência da água para a cultura do citros situa-se entre 2 e 5 o que reafirma a baixa performance da Tangerina Cleópatra ao ecossistema avaliado na medida em que este material apresenta o valor que mais se aproxima do limite mínimo de EUA estabelecido para esta cultura. 


\section{CONCLUSÕES}

1 - A presença de uma camada adensada próxima à superficie do solo, associada ao regime climático característico da unidade geoambiental estudada promove importantes alterações no potencial de água e na aeração do solo com graves reflexos na dinâmica da água no solo e no desenvolvimento do sistema radicular dos citros.

2 - As diferenças observadas entre os porta-enxertos quanto à configuração do sistema radicular permitem pressupor que os materiais com menor volume de raizes são mais adaptados à exploração dos citros no ecossistema estudado. O Limão Cravo é, entre os porta-enxertos avaliados, o que melhor se ajusta a esta condição.

3 - Com base nas taxas de evapotranspiração apresentadas pelos porta-enxertos nos estádios fenológicos de grande demanda hídrica é possivel concluir que a Tangerina Cleópatra é o porta-enxerto menos adaptado e o Limão Cravo o que apresenta as melhores características de adaptação ao ecossistema.

4 - Por atuar como barreira fisica às perdas de água do solo no momento em que as chuvas escasseiam, a camada coesa pode funcionar como meio regulador do suprimento de água para as plantas nos meses de maior demanda hídrica dos citros os quais precedem a estação chuvosa. 


\section{REFERÊNCIAS BIBLIOGRÁFICAS}

ATKINSON, D. The distribution and effectiveness of the root of the crops. Horticultural Reviews, v.2, p.424-490, 1980.

AVILAN, L.R.; MENESES, L.; SUCRE, R.; PÉREZ, O.G.; BELARDI, C. Efecto de algunas propriedades fisicas del suelo sobre la distribution y la produccion en citricas. Agronomia Tropical, v.29, n.5, p.413-427, 1979.

BEVINGTON, K.B.; CASTLE, W.S. Annual root growth pattern of young citrus trees in relation to shoot growth, soil temperature and soil water content. Journal of the American Society for Horticultural Science, v.110, n.6, p.840-845, 1985.

BRASIL. Ministério das Minas e Energia. Projeto Radambrasil. Folhas SC 24/25 Aracaju/Recife: geomorfologia, pedologia, vegetação e uso potencial da terra. Rio de Janeiro, 1983. 856p. (Volume, 30).

CALLOT, G.; CHAMYOU, H.; MAERTENS, C.; SALSAC, L. Mieux comprendre les interactions sol-racine. Paris:Institut National de la Recherche Agronomique, 1982. $325 p$.

CASTLE, W.S. Fibrous root distribution of 'pineapple'orange trees on rough lemon rootstock at tree spacings. Journal of the American Society for Horticultural Science, v. 105, n.3, p.478-480, 1980. 
CASTLE, W.S.; KREZDORN, A.H. Rootstock effects on root distribution and leaf mineral content of 'Orlando' tangelo trees. Proceedings of Florida State Horticultural Society, v. 86, p.80-84, 1973.

CASTLE, W.S.; KREZDORN, A.H. Some physical and chemical characteristcs of a deep wee-drenaid soil planted to citrus. Proceedings of the Florida State Horticultural Society, v.88, p.23-29, 1975.

CASTLE, W.S.; KREZDORN, A.H. Soil water use and apparent root efficiencies of citrus tree on four rootstocks. Journal of the American Socierty for Horticultural Science, v. 102, n.4, p.403-406, 1977.

CASTLE, W.S.; TUCKER, D.R.H.; KREZDORN, A.H.; YOUTSEY, C.O. Rootstocks for Florida citrus: rootstock selection the first step to success. Gainesville:University of Florida, Institute of Food and Agricultural Sciences, 1989. $48 \mathrm{p}$.

CASTRO, P.R.C. Como a seca afeta os citros. Laranja \& Cia, v.40, p.4, 1995.

CINTRA, F.L.D.; NEVES, C.S.V.J. Aspectos metodológicos do estudo do sistema radicular de plantas perenes através de imagens. Boletim Informativo da Sociedade Brasileira de Ciência do Solo, v.21, n.3, p.91-94, 1996.

CHOPART, J.L. Etude ao champ des systemes racinaires des principales cultures pluviales au Senegal (arachide-mil-sorgho-riz pluvial). Toulouse, 1980. 160p. Thèse (Docteur) - Institut National Polytechnique de Toulouse.

CRUVINEL, P.E.; CRESTANA, S.; JORGE, L.A.C. de. Métodos e aplicações do processamento de imagens digitais. In: CRESTANA, S.; CRUVINEL, P.E.; MASCARENHAS, S.; BISCEGLI, C.I.; MARTIN NETO, L; COLNAGO, L.A. 
(Ed.) Instrumentação agropecuária; contribuições no limiar do novo século. Brasília:EMBRAPA,SPI, 1996. cap.3, p.91-151.

DRIESSEN, P.M.; DUDAL, R. (Ed.) The major soils of the world: lecture notes on their geograph, formation, properties and use. Wageningen:Agricultural University Wageningen,Department of Soil Science and Geology, 1991. 310p.

DOORENBOS, J.; KASSAN, A.H. Effectos del agua sobre rendimiento del los cultivos. Roma:FAO, 1979. 212p. (Estudio FAO:Riego y Drenaje, 33).

DOURADO NETO, D; JONG VAN LIER, Q. de; BOTREL T.A.; LIBARDI, P.L. Programa para confecção da água no solo utilizando o modelo de Genuchten. Engenharia Rural, v.1, p.92-102, 1990.

EAVIS, B.W. Soil physical conditions affecting seedling root growth I. Mechanical impedance, aeration and moisture availability as influenced by bulk density and moisture levels in a sandy loam soil. Plant and Soil, v.36, p.613-622, 1972.

EMPRESA BRASILEIRA DE PESQUISA AGROPECUÁRIA. Centro de Pesquisa Agropecuária dos Tabuleiros Costeiros. Plano diretor do Centro de Pesquisa Agropecuária dos Tabuleiros Costeiros (CPATC). Brasília:EMBRAPA,SPI, 1994. $37 \mathrm{p}$.

EMPRESA BRASILEIRA DE PESQUISA AGROPECUÁRIA. Superintendência de Desenvolvimento do Nordeste. Levantamento exploratório-reconhecimento de solos do estado de Sergipe. Recife:EMBRAPA,Centro de Pesquisas Pedológicas. 1975, 506p. (Boletim Técnico, 36) 
EMPRESA BRASILEIRA DE PESQUISA AGROPECUÁRIA. Serviço Nacional de Levantamento e Conservação do Solo. Manual de métodos de análise de solo. Rio de Janeiro: EMBRAPA, SNLCS. 1979. s.p.

ESTADOS UNIDOS. Soil Survey Staff. Keys to soil taxonomy 5.ed. Blacksburg: Virginia Politechnic Institute, 1992. 556p. (SMSS Technical Monograph, 19).

FIGUEIREDO, J.O. de. Variedades copa de valor comercial. In: RODRIGUEZ, O.; VIÉGAS, J.; POMPEU JÚNIOR, J.; AMARO, A.S. (Ed.) Citricultura brasileira 2.ed. Campinas:Fundação Cargill, 1991. v.1, p.228-264.

FORD, H.W. The influence of rootstock and tree age on root distribution of citrus. Proceedings of the American Society for Horticultural Science, v.63, p.137-142, 1954.

FORSYTHE, W.M. Las propriedades fisicas, los factores fisicos de crescimiento y la productividad del suelo. Fitotecnia Latinoamericana, v.4, n.2, p. 165-176, 1967.

FREITAS, P.L.; BLANCANEAUX, P. Metodologia de pesquisa em manejo do solo: estrutura e porosidade do solo./Apresentado na Reunião sobre Metodologia de Pesquisa em Manejo do Solo, Passo Fundo, 1988/.

HAGIN, J.; LIFSHITZ, Z.; MONSELISE, S.P. The influence of soil aeration on the growth of citrus. Israel Journal of Agricultural Research, v. 15, n.2, p.59-64, 1965.

HASSAN, M.M. Effect of citrus rootstock on root distribution tree growth and leaf mineral composition of 'washington'navel orange trees. Egypty Journal of Horticultural, v.11, n.2, p.201-207, 1984. 
HAYNES, J.L. Uso agrícola dos tabuleiros costeiros do Nordeste do Brasil: um exame das pesquisas. 2.ed. Recife:SUDENE/AID, 1970. 139p.

HILLEL, D. Solo e água: fenômenos e princípios físicos. Porto Alegre:UFRGS, Departamento de solos, 1970. 231p.

HILLEL, D. The field water balance and water use efficiency. In: HILLEL, D. (Ed.) Optimizing the soil physical environment toward greater crop yields. New York:Academic Press, 1972. p.79-100.

JACOMINE, P.K.T. Distribuição geográfica, características e classificação dos solos coesos dos tabuleiros Costeiros. In REUNIÃO TÉCNICA SOBRE SOLOS COESOS DOS TABULEIROS COSTEROS, Cruz das Almas, 1996. Anais. Aracaju:EMBRAPA,CPATC; EMBRAPA,CNPMF; IGUFBA, 1996. p.13-26.

JONES, W.W.; EMBLETON, T.W. Soil managment and cover crops. In: REUTHER, W. (Ed.) The citrus industry. Riverside:University of California, 1973. v.3, cap.4, p. $98-121$.

JORGE, L.A C.; CRESTANA, S Recomendações práticas para utilização do SIARCS 3.0 nos estudos de raízes, cobertura vegetal, folhas e outras aplicações. São Carlos:EMBRAPA,CNPDIA, $1996.34 \mathrm{p} . \quad$ (EMBRAPA.CNPDIA. Recomendação Técnica, 4)

JORGE, L.A.C.; RALISCH, R.; ABI SAAB, J.G.; MEDINA, C.C.; GUIMARÃES, M.F.; NEVES, C.S.V.J.; CRESTANA, S.; CINTRA, F.L.D.; BASSOI, L.H.; FERNANDES, S.B.V. Aquisição de imagens de raízes. In: JORGE, L.A.C. (Ed) Recomendações práticas para aquisição de imagens digitais analisadas através do SIARCS. São Carlos:EMBRAPA,CNPDIA, 1996. cap.1. (Circular Técnica, 1). 
KLUTE, A. The determination of the condutivity and difusivity of unsatureted soils. Soil Science, v.113, n.4, p.264-276, 1972.

KLUTE, A.; DIRKSEN, C. Hydraulic condutivity and diffusivity: laboratory methods. 2.ed. In: Methods of soil analysis: physical and mineralogical methods. 2.ed. Madison: American Society of Agronomy,Soil Science Society of America, 1986. Cap.28, p.687-734.

KOLESNIKOV, V. The root system of fruit plant. Moscow:Mir Publishers, 1971. $255 \mathrm{p}$.

KURIEN, S.; GOSWAMI, A.M.; DEB, D.L. Scionic influence on root activity in citrus using a radiotracer technique. Fruits, v.49, n.4, p.261-267, 1994.

LETEY, J. Relationship between soil physical properties and crop production. Advences in Soil Science, v. 1, p.277-294, 1985.

LIBARDI, P.L. Condutividade hidráulica em condições de campo. Piracicaba, 1978. 142p. Tese (Doutorado) - Escola Superior de Agricultura "Luiz de Queiroz", Universidade de São Paulo.

LIBARDI, P.L. Dinâmica da água no solo. Piracicaba: o autor, 1995. 497p.

LIBARDI, P.L. ; REICHARDT, K. ; NIELSEN, D.R. ; BIGGAR, J.W. Simplified field methods for estimating the unsaturated hydraulic conductivity. Soil Science Society of American Journal, v.44, n. 1, p.3-6, 1980.

LIMA, J.E.O.de. A falta de água na planta cítrica. Laranja \& Cia, v.40, p.5, 1995. 
LUC, J. Caracterization hydrique des sols: utilization des mesures d'humidité et de charge in situ, comparaison avec les mesures de laboratoire, 1978. 169p. Thèse (Docteur) - Academie de Montpellier, Université des Sciences et Techniques du Languedoc.

MECHLIA, NB.; CARROLL, J.J. Agroclimatic modeling for simulation of phenology, yield and quality of crop production; I. citrus response formulation. International Journal of Meteorology, v.33, n. 1, p.36-51, 1989.

MIKHAI, E.H.; EL-ZEFTAWI, B.M. Effect of soil types and rootstocks on root distribution, chemical composition of leaves and yield of Valencia oranges. Australian Journal of Soil Research., v.17, p.335-342, 1979.

MONIZ, A.C. Evolução de conceitos no estudo da gênese de solos. Revista Brasileira de Ciência do Solo, v.20, n.3, p.349-362, set/dez. 1996.

NYE, P.H.; THINKER, P.B. Solute movement in the soil-root system. London:Blackwel Scientific, 1977. 341p.

OLIVEIRA, J.B.de. Solos para citros. RODRIGUEZ, O.; VIÉGAS, J.; POMPEU JÚNIOR, J. AMARO, A.S. (Ed.) Citricultura brasileira, 2.ed. Campinas:Fundação Cargill, 1991. v.1, p.196-227.

ORTOLANI, A.A.; PEDRO JÚNIOR, M.J.; ALFONSI, R.R. Agroclimatologia e o cultivo dos citros. In: RODRIGUEZ, O.; VIÉGAS, J.; POMPEU JÚNIOR, J.; AMARO, A.S. (Ed.) Citricultura brasileira, 2.ed. Campinas:Fundação Cargill, 1991. v.1, p.153-195.

PACE, C.A.M.; ARAUJO, C.M. Estudo da distribuição do sistema radicular de portaenxertos cítricos em solos podzolizados e sua relação com a formação de copas. In: 
CONGRESSO BRASILEIRO DE FRUTICULTURA, 8., Brasília, 1986. Anais. Brasilia:EMBRAPA,DDT,CNPQ, 1986. p.199-205.

PEARSON, R.W. Soil environment and root development. In: PIERRE, W.H. et al. (Ed) Plant environment and efficient water use. Madison:American Society of Agronomy/Soil Science Society of America, 1966. cap.6, p.95-126.

POMPEU JÚNIOR, J. Porta-enxertos. In: RODRIGUEZ, O.; VIÉGAS, J.; POMPEU JÚNIOR, J.; AMARO, A.S. (Ed.) Citricultura brasileira. 2.ed. Campinas:Fundação Cargill, 1991. v.1, p.265-280.

REICHARDT, K. A água na produção agrícola. São Paulo:McGraw-Hill do Brasil, 1978. $119 \mathrm{p}$.

REICHARDT, K. Capacidade de campo. Revista Brasileira de Ciência do Solo, v.12, p.211-216, 1988.

REUNIÃO TÉCNICA SOBRE SOLOS COESOS DOS TABULEIROS COSTEIROS, Cruz das Almas;Aracaju, 1996. Solos coesos dos tabuleiros da Bahia e Sergipe. Cruz das Almas;Aracaju: UFBA;EMBRAPA/CNPMF/CPATC, 1996a. 4lp. (Guia de Excursão).

REUNIÃO TÉCNICA SOBRE SOLOS COESOS DOS TABULEIROS COSTEIROS. Cruz das Almas, 1996. Resumo executivo. Cruz das Almas: UFBA, Escola de Agronomia, 1996b. 12p.

REUTHER, W. Climate and citrus behavior. In: REUTHER, W. (Ed.) The citrus industry. Berkeley:University of California, 1973. v.3, cap.9, p.280-337. 
RIBEIRO, L.P. Primeiras avaliações sobre a gênese dos solos coesos da Região de Cruz das Almas-BA. In: TABLE ROUNDE SUR L'ORGANIZATION ET DINAMIQUE INTERNE DE LA COVERTURE PEDOLOGIQUE ET SON IMPORTANCE POUR LA COMPREENSION DE LA MORFOGÊNESE, Caen, 1991. Caen:CNRS, 1991. 35p.

RIBEIRO, L.P. Horizontes coesos em latossolos de tabuleiros. In: SEMANA DE GEOQUÍMICA, 9.; CONGRESSO DE GEOQUÍMICA DOS PAÍSES DE LÍNGUA PORTUGUESA, 2., Porto, 1993. Porto:Universidade do Porto;Faculdade de Ciências e Laboratório Mineralógico, 1993. p.496-500. (Memórias, 3).

RITCHIE, J.T.; AMATO, M. Field evaluation of plant extractable soil water for irrigation scheduling. Acta Horticulturae, v.278, p.595-615, 1990.

RUSSELL, R.S. Plant root system-their function and interation with the soil. In: SYMPOSIUM ON THE SOIL ROOT SYSTEM, Londrina, 1980. The soil/root system in relation to brazilian agriculture. Londrina:IAPAR, 1981. p.3-19.

SAKOVICH, N.J. Lemon root distribution in sprinkler drip systems. Citrograph, v.71, n.7, p.143-144, May 1986.

SCHNEIDER, H. The anatomy of citrus. In: REUTHER, W.; BATCHELOR, L.D.; WEBBER, H.J. (Ed.) The citrus industry. Berkeley:University of California, 1968. v.2, cap.1, p.1-85.

SHALHEVET, J.; LEVY, Y. Citrus tree. In: SHALHEVET, J.; LEVY, Y. (Ed) Irrigation of Agricultural crops. Madison:ASA/CSSA/SSSA, 1990, p.951-985. (Monograph, 30). 
SILVA, A.P.da; KAY, B.D.; PERFECT, E. Characterization of the least limiting water range of soil. Soil Science Society of American Journal, v.58, p. 1775-1781, 1994.

SILVA, F.B.R.; RICHÉ, G.R.; TONNEAU, J.P. et al. Zoneamento agroecológico do Nordeste: diagnóstico do quadro natural e agrossocioeconômico. Petrolina: EMBRAPA,CPATSA,CNPS, 1993. 2v.

SILVA, L.F.da. Manejo dos recursos naturais dos trópicos e suas consequência, contradições e perspectivas de uso em agricultura sustentável. Agrotrópica, v.3, n.1, p.15-22, 1991.

SOUZA, L.S. Aspectos sobre o uso e manejo dos solos coesos dos tabuleiros costeiros. Boletim Informativo da Sociedade Brasileira de Ciência do Solo, v.22, n. 1, p.3439, 1997.

TAYLOR, H.M. Root behavior as affected by soil structure and strenght. In: CARSON (Ed.) The plant root and its environment. Virginia:University Press of Virginia, 1974. cap.2, p.271-291.

TAYLOR, H.M.; MATHERS, A.C.; LOTSPEICH, F.B. Pans in southern great plains soils: why root-restricting pans occur. Agronomy Journal, v.56, p.328-332, 1964.

THINKER, P.B. Root distribution and nutrient uptake. In: SYMPOSIUM ON THE SOIL/ROOT SYSTEM, Londrina, 1980. The soil/root system in relation to brazilian agriculture. Londrina:IAPAR, 1981. p.115-136.

TUZCU, O.; HUGUET, J.G.; KAPLANKIRAN, M. Comparaison des performances racinaires de dix port-greffe des agrumes en Turquie sur sol argilo-limoneux. Fruits, v.36, n.11, p.711-718, 1981. 
UNGER, P.W.; KASPAR, T.C. Soil compaction and root growth: a review. Agronomy Journal, n.5, p.759-766, 1994.

VAN GENUCHTEN, M.Th. A closed-form equation for predicting the hydraulic conductivity of unsatureted soils. Soil Scienci Society of American Journal, v.44, n. 5, p. $892-898,1980$.

VIEIRA, D.B. Irrigação de citros. In: RODRIGUEZ, O.; VIÉGAS, J.; POMPEU JÚNIOR, J.; AMARO, A.S. (Ed.) Citricultura brasileira, 2.ed. Campinas:Fundação Cargill, 1971. v.2., p.153-195.

WELLER, F. A method for studying the distribution of absorbing roots of fruits trees. Experimental Agriculture, v.7, p.351-361, 1971.

WIERSUM, L.K. The relationship of the size and structure rigidity of pores to their penetration by roots. Plant and Soil, v.9, n.1, p-75-85, 1957.

WILLMOTT, C.J. On the validation of models. Physical Geography, v.2, p.184-194, 1981. 